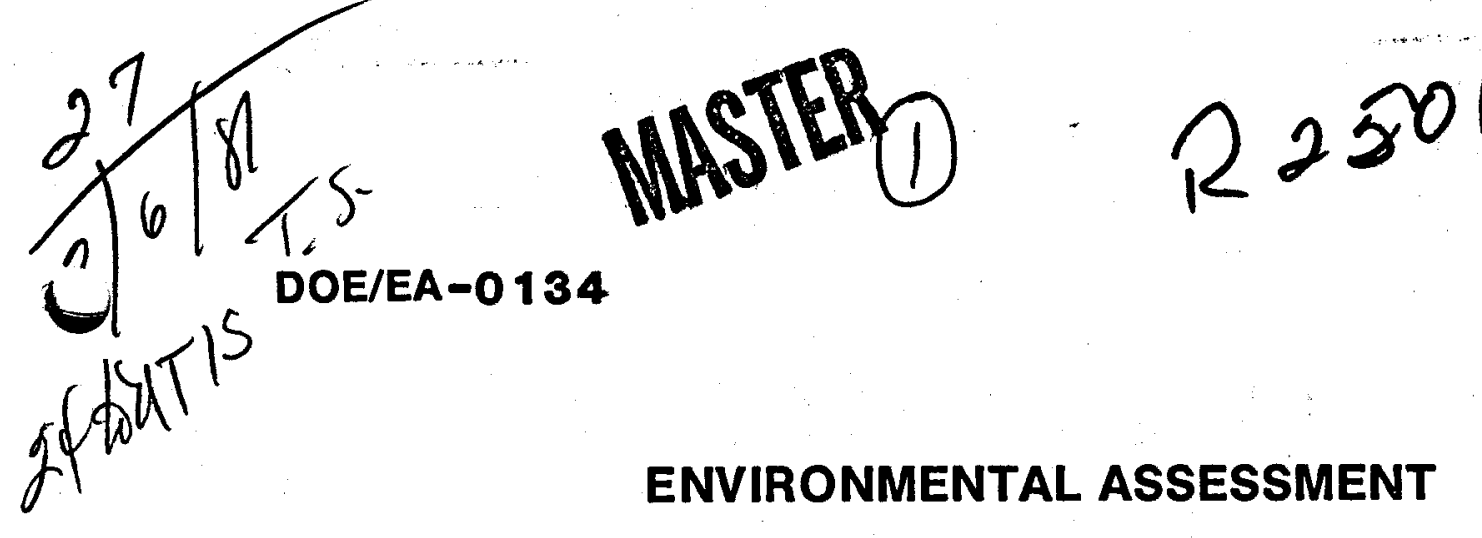

\title{
Geothermal Energy Geopressure Subprogram
}

Gladys McCall Well Site

CAMERON PARISH, LOUISIANA

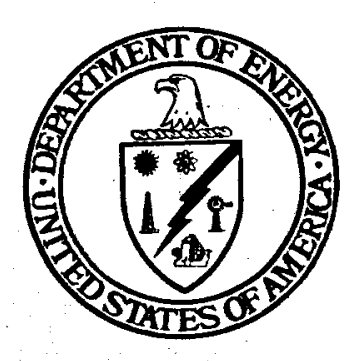

FEBRUARY 1981

\author{
U.S. DEPARTMENT OF ENERGY \\ Assistant Secretary for Resource Applications \\ Division of Geothermal Energy \\ Washington, D.C. 20461
}




\section{DISCLAIMER}

This report was prepared as an account of work sponsored by an agency of the United States Government. Neither the United States Government nor any agency Thereof, nor any of their employees, makes any warranty, express or implied, or assumes any legal liability or responsibility for the accuracy, completeness, or usefulness of any information, apparatus, product, or process disclosed, or represents that its use would not infringe privately owned rights. Reference herein to any specific commercial product, process, or service by trade name, trademark, manufacturer, or otherwise does not necessarily constitute or imply its endorsement, recommendation, or favoring by the United States Government or any agency thereof. The views and opinions of authors expressed herein do not necessarily state or reflect those of the United States Government or any agency thereof. 


\section{DISCLAIMER}

Portions of this document may be illegible in electronic image products. Images are produced from the best available original document. 
Avallable from:

Mational Techolcal Information Service (NTIS)

T.S. Department of Cosmerce

3285 Port Royal Road

Springfield, Virginia 22161

Price: Printed cops: $\$ 17.00$

Ylerof Iche: $\$ 3.50$ 


\title{
Geothermal Energy \\ Geopressure Subprogram
}

\author{
Gladys McCall Well Site \\ CAMERON PARISH, LOUISIANA
}

FEBRUARY 1981

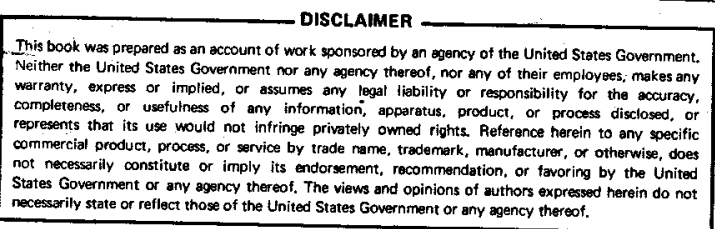

\section{U.S. DEPARTMENT OF ENERGY}

Assistant Secretary for Resource Applications Division of Geothermal Energy

Washington, D.C. 20461 
List of Tables $\ldots \ldots \ldots \ldots \ldots \ldots \ldots \ldots \ldots \ldots \ldots \ldots \ldots \ldots \ldots \ldots \ldots \ldots \ldots \ldots$ viii

List of Figures $\ldots \ldots \ldots \ldots \ldots \ldots \ldots \ldots \ldots \ldots \ldots \ldots \ldots \ldots \ldots \ldots \ldots \ldots \ldots \ldots \ldots \ldots$

Glossary and Abbreviations $\ldots \ldots \ldots \ldots \ldots \ldots \ldots \ldots \ldots \ldots \ldots \ldots \ldots \ldots \ldots$

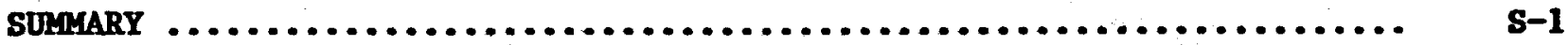

References $\ldots \ldots \ldots \ldots \ldots \ldots \ldots \ldots \ldots \ldots \ldots \ldots \ldots \ldots \ldots \ldots \ldots \ldots \ldots \ldots \ldots \ldots \ldots . . . \ldots$

CEAPTER ONE - DESCRIPTION OF THE PROPOSED ACTION ............... 1-1

1.1 Introduction $\ldots \ldots \ldots \ldots \ldots \ldots \ldots \ldots \ldots \ldots \ldots \ldots \ldots \ldots \ldots \ldots \ldots \ldots \ldots \ldots \ldots \ldots \ldots$ 1-1

1.2 Site Location and Surface Features $\ldots \ldots \ldots \ldots \ldots \ldots \ldots \ldots \ldots \ldots \ldots \ldots \ldots \ldots \quad 1-4$

1.2 .1 The Region $\ldots \ldots \ldots \ldots \ldots \ldots \ldots \ldots \ldots \ldots \ldots \ldots \ldots \ldots \ldots \ldots \ldots \ldots$

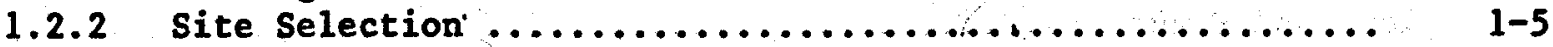

1.2 .3 Description of the Proposed Well Site
and Study Area $\ldots \ldots \ldots \ldots \ldots \ldots \ldots \ldots \ldots \ldots \ldots \ldots \ldots \ldots \ldots \ldots \ldots \ldots$

1.3 Project Description $\ldots \ldots \ldots \ldots \ldots \ldots \ldots \ldots \ldots \ldots \ldots \ldots \ldots \ldots \ldots \ldots \ldots \ldots \ldots \ldots$

1.3 .1 Construction and Drilling ..................... 1-9

1.3.1.1 Site and Access Preparation ................. 1-9

1.3.1.2 Well Drilling and Testing ................. 1-11

1.3.1.3 Environmental Monitoring Program ............ 1-17

1.3.1.4 Long-Term Activities ....................... 1-18

1.3 .1 .5 Accidents ........................... 1-19

1.4 Environmental Issues and Mitigation Measures $\ldots \ldots \ldots \ldots \ldots \ldots \ldots \ldots \ldots \ldots$ 1-22

1.4.1. Environmental Issues

1.4.1.1 Physical and Biological Issues -

A Summary of Adverse Impacts ............... 1-22

1.4.1.2 Cultural Issues - A Summary of Adverse ${ }_{\text {Impacts } \ldots \ldots \ldots \ldots \ldots \ldots \ldots \ldots \ldots \ldots \ldots \ldots \ldots \ldots \ldots \ldots} 1-24$

1.4 .1 .3 Economic Issues - A Summary of Adverse
Impacts $\ldots \ldots \ldots \ldots \ldots \ldots \ldots \ldots \ldots \ldots \ldots \ldots \ldots \ldots \ldots \ldots \ldots \ldots \ldots \ldots$
$1-25$

1.4 .2 Sumary of Mitigation Measures .................. 1-25

References $\ldots \ldots \ldots \ldots \ldots \ldots \ldots \ldots \ldots \ldots \ldots \ldots \ldots \ldots \ldots \ldots \ldots \ldots \ldots \ldots \ldots \ldots \ldots \ldots{ }_{1-28}$

CHAPTER TWO - EXISTIMG ENVIROMMENT $\ldots \ldots \ldots \ldots \ldots \ldots \ldots \ldots \ldots \ldots \ldots \ldots \ldots \ldots \ldots \ldots$ 2-1

2.1 Introduction $\ldots \ldots \ldots \ldots \ldots \ldots \ldots \ldots \ldots \ldots \ldots \ldots \ldots \ldots \ldots \ldots \ldots \ldots \ldots \ldots \ldots \ldots$ 2-1 


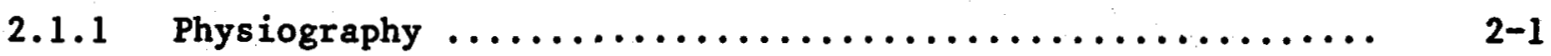

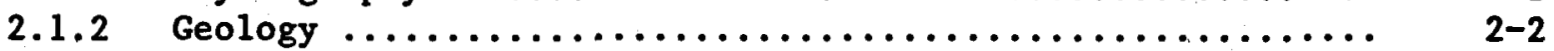

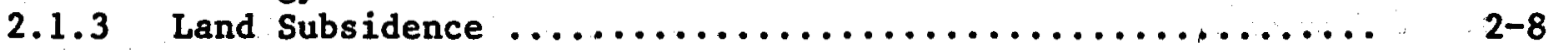

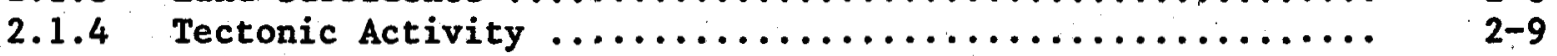

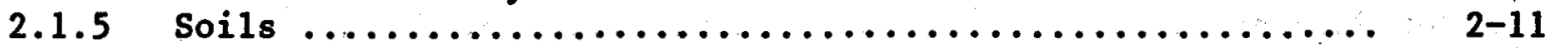

2.1 .6 Prime and Unique Farmland .................... 2-11

2.2 Hydrology and Water Dse $\ldots \ldots \ldots \ldots \ldots \ldots \ldots \ldots \ldots \ldots \ldots \ldots \ldots \ldots \ldots \ldots \ldots . \ldots \ldots$

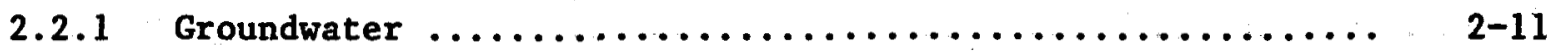

2.2.1.1 Occurrence ......................... 2-11

2.2 .1 .2 Quality ............................ 2-12

2.2.1.3 Quantity ............................ 2-13

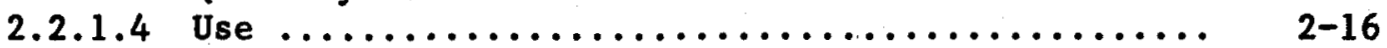

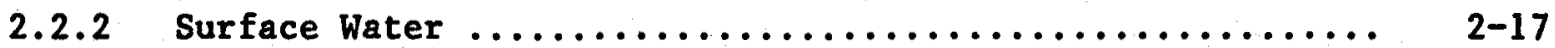

2.2.2.1. General Basin Hydrology ................. 2-18

2.2.2.2 Water Quality Characteristics .............. 2-21

2.2.2.3 Water Resource Development ................. 2-23

2.2.2.4 Floodplains/Wetlands ................... 2-25

2.3 Flora and Fauna $\ldots \ldots \ldots \ldots \ldots \ldots \ldots \ldots \ldots \ldots \ldots \ldots \ldots \ldots \ldots \ldots \ldots \ldots \ldots \ldots \ldots$

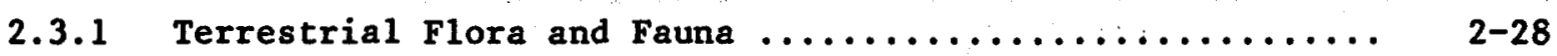

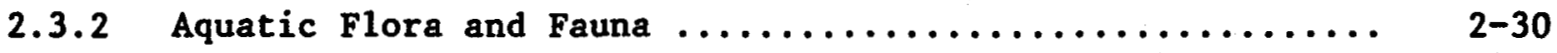

2.4 Endangered Species $\ldots \ldots \ldots \ldots \ldots \ldots \ldots \ldots \ldots \ldots \ldots \ldots \ldots \ldots \ldots \ldots \ldots \ldots \ldots \ldots . \ldots \ldots$

2.5 Noise $\ldots \ldots \ldots \ldots \ldots \ldots \ldots \ldots \ldots \ldots \ldots \ldots \ldots \ldots \ldots \ldots \ldots \ldots \ldots \ldots \ldots \ldots \ldots \ldots \ldots \ldots \ldots 2-31$

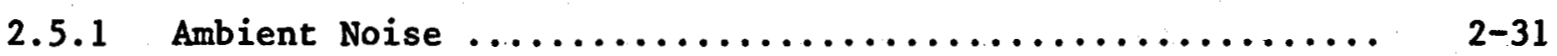

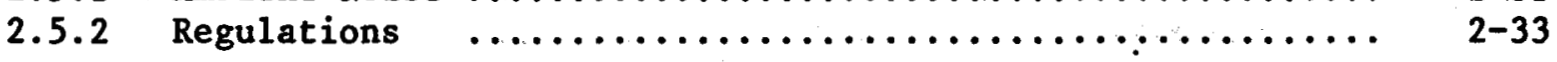

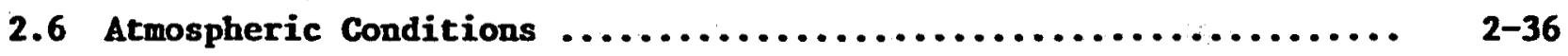

2.6.1 Regional Climatology ........................ 2-36

2.6.2 Meteorology Near the Study Area ................... 2-38

2.6 .3 Air Quality .............................. 2-40

2.7 Unique Resources $\ldots \ldots \ldots \ldots \ldots \ldots \ldots \ldots \ldots \ldots \ldots \ldots \ldots \ldots \ldots \ldots \ldots \ldots \ldots \ldots \ldots \ldots . . \ldots 2-42$

2.7.1 Recreational Areas, Existing and Proposed ........... 2-42

2.7.2 Archaeological Sites ......................... 2-43

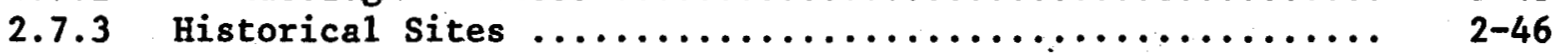

2.8 Demographic and Socio-Economic Setting .................... 2-46

2.8.1 Demography ................................... 2-46

2.8 .2 Ethnic Groups ............................... 2-47

2.8.3 Socio-economic Characteristics .................... 2-47

2.8.3.1 Agricultura1 Economy .................. 2-48

2.8.3.2 Petroleum Extraction ................... 2-48 
CRAPTER TRREE - PROBABLE MPACTS - DIRECT AND INDIRECT . . . . . . . . . .

3.1 Impacts Due to Site Preparation and Construction .............. 3-1

3.1.1 Geology

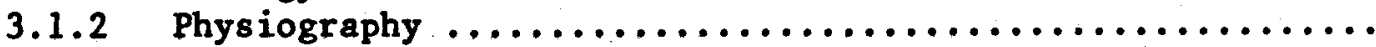

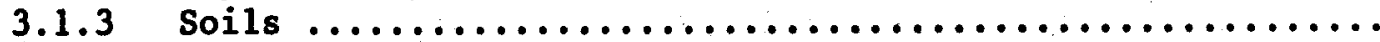

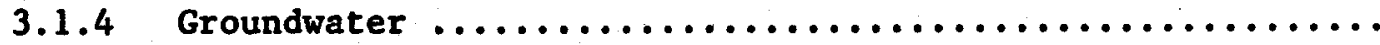

3.1 .5 Surface Water $\ldots \ldots \ldots \ldots \ldots \ldots \ldots \ldots \ldots \ldots \ldots \ldots \ldots \ldots \ldots \ldots \ldots \ldots \ldots, 3-1$

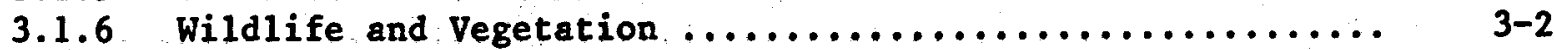

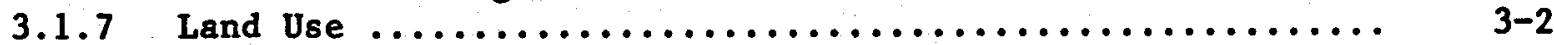

3.1.8 Socio-economic ............................. $3-2$

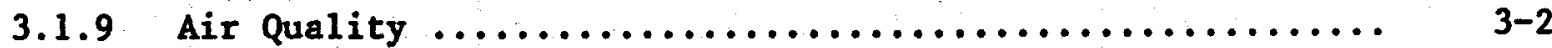

3.1.10 Recreational, Archaeological and Historical

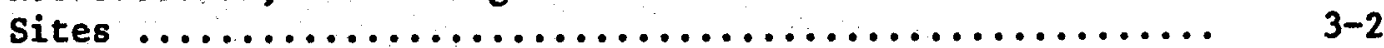

3.1.11 Federal, State, Regional and Local Land

Use Programs ............................... 3-2

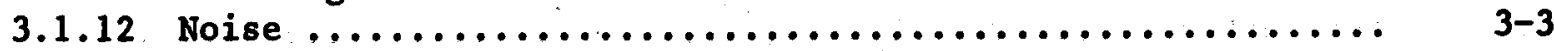

3.2 Impacts Due to Drilling and Maintenance $\ldots \ldots \ldots \ldots \ldots \ldots \ldots \ldots \ldots \ldots$

$3.2 .1 \quad$ Geology $\ldots \ldots \ldots \ldots \ldots \ldots \ldots \ldots \ldots \ldots \ldots \ldots \ldots \ldots \ldots \ldots \ldots \ldots \ldots . \ldots \ldots$

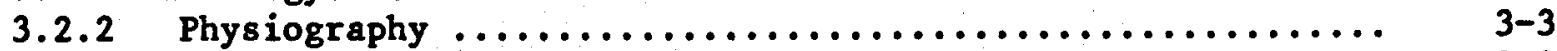

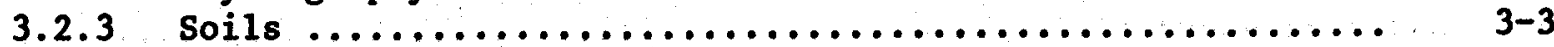

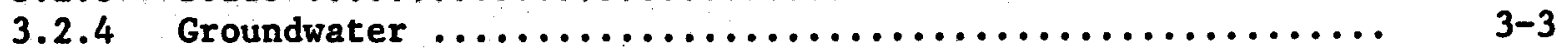

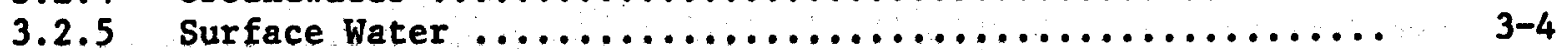

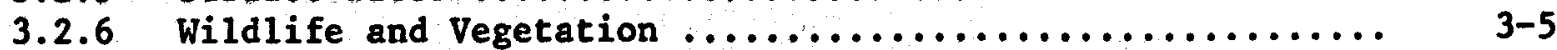

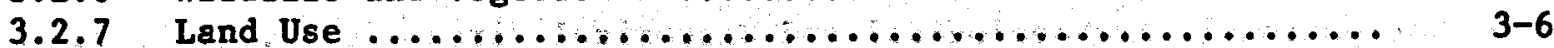

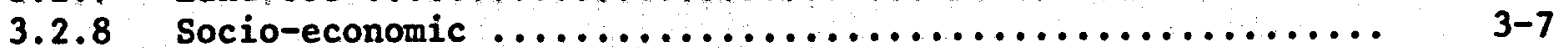

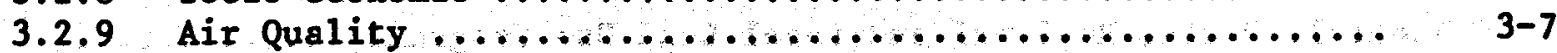

3.2.10 Recreationa1, Archaeological and Historical

Sites $\ldots \ldots \ldots \ldots \ldots \ldots \ldots \ldots \ldots \ldots \ldots \ldots \ldots \ldots \ldots \ldots \ldots \ldots \ldots \ldots, \ldots \ldots \ldots$

3.2.11 Federal, State, Regional and Local Land Use

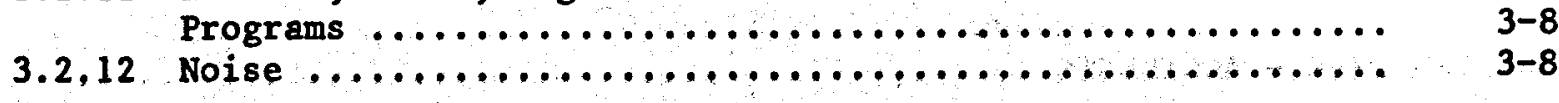

3.3 Impacts Caused by Flow-testing or Operation of the Proposed

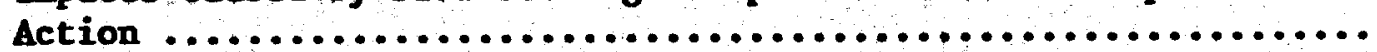

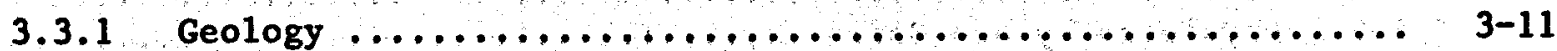

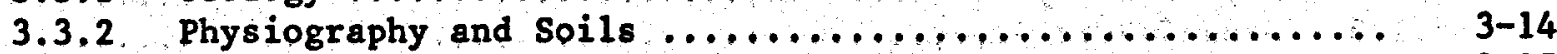

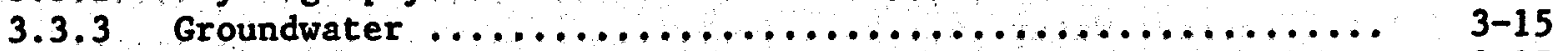

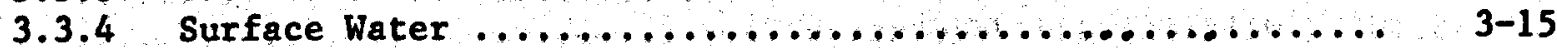

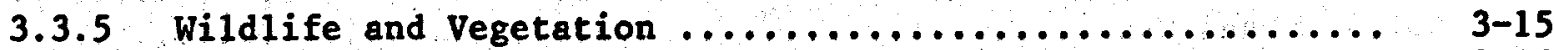

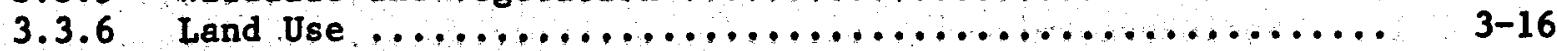

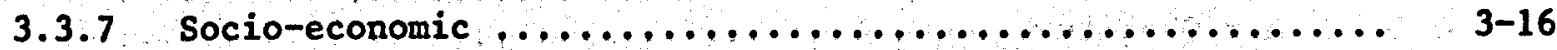

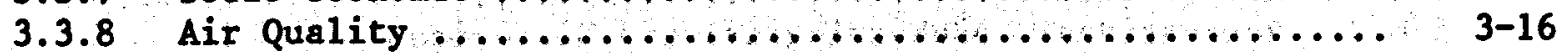

3.3.9 Recreational, Archaeological and Historical

Sites ................................... 3-18 
3.3.10 Federal, State, Regional, and Local Land Use

Programs .................................. 3-19

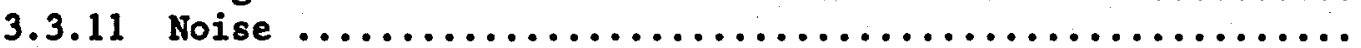

3.4 Impacts on Floodplains and Vetlands ......................... 3-19

3.5 Unavoidable Direct and Indirect Impacts .................... 3-21

References $\ldots \ldots \ldots \ldots \ldots \ldots \ldots \ldots \ldots \ldots \ldots \ldots \ldots \ldots \ldots \ldots \ldots \ldots \ldots \ldots \ldots \ldots \ldots \ldots \ldots \ldots \ldots$ 3-24

CHAPTER FOUR - PROBABLE CULULATIVE AND LONG-TERM ENVIROMLGITTAL TFEBCTS

4.1 Geology.

4.2 Physiography and Soils

4-1

4-1

4.3 Groundwater $\ldots \ldots \ldots \ldots \ldots \ldots \ldots \ldots \ldots \ldots \ldots \ldots \ldots \ldots \ldots \ldots \ldots \ldots \ldots \ldots \ldots . \ldots \ldots$ 4-2

4.4 Surface Water $\ldots \ldots \ldots \ldots \ldots \ldots \ldots \ldots \ldots \ldots \ldots \ldots \ldots \ldots \ldots \ldots \ldots \ldots \ldots \ldots \ldots \ldots \ldots$ 4-2

4.5 Vildlife and Vegetation $\ldots \ldots \ldots \ldots \ldots \ldots \ldots \ldots \ldots \ldots \ldots \ldots \ldots \ldots \ldots \ldots . \ldots . \ldots . \ldots$

4.6 Land Use $\ldots \ldots \ldots \ldots \ldots \ldots \ldots \ldots \ldots \ldots \ldots \ldots \ldots \ldots \ldots \ldots \ldots \ldots \ldots \ldots \ldots \ldots . \ldots \ldots \ldots$

4.7 Socio-economic $\ldots \ldots \ldots \ldots \ldots \ldots \ldots \ldots \ldots \ldots \ldots \ldots \ldots \ldots \ldots \ldots \ldots \ldots \ldots \ldots \ldots \ldots . . \ldots$

4.8 Air Quality $\ldots \ldots \ldots \ldots \ldots \ldots \ldots \ldots \ldots \ldots \ldots \ldots \ldots \ldots \ldots \ldots \ldots \ldots \ldots \ldots \ldots \ldots \ldots \ldots . . \ldots$

4.9 Recreational, Archaeological and Historical Sites ............ 4-4

4.10 Federal, State, Regional and Local Land Dse Programs .......... 4-4

4.11 Noise $\ldots \ldots \ldots \ldots \ldots \ldots \ldots \ldots \ldots \ldots \ldots \ldots \ldots \ldots \ldots \ldots \ldots \ldots \ldots \ldots \ldots \ldots \ldots \ldots \ldots \ldots . . \ldots$

CHAPTER FIVE - ACCIDENTS $\ldots \ldots \ldots \ldots \ldots \ldots \ldots \ldots \ldots \ldots \ldots \ldots \ldots \ldots \ldots \ldots \ldots \ldots \ldots . . \ldots$

5.1 Accidents During Site Preparation and Access Construction ....... 5-4

$5.1 .1 \quad$ Geology ................................... $5-4$

5.1 .2 Physiography and Soils ........................

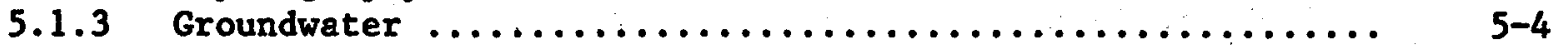

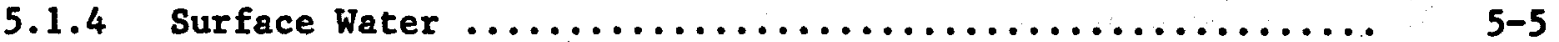

5.1 .5 Wildlife and Vegetation $\ldots \ldots \ldots \ldots \ldots \ldots \ldots \ldots \ldots \ldots \ldots \ldots \ldots \ldots$

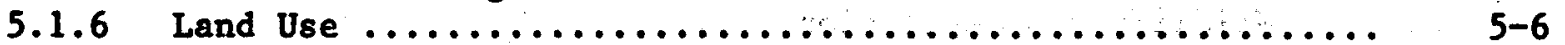

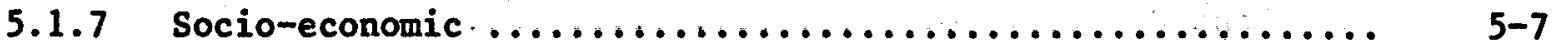

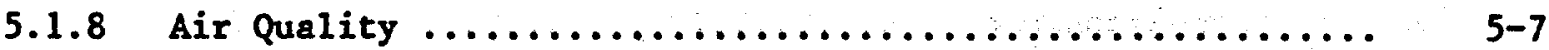

5.1.9 Recreational, Archaeological and Historical Sites $\ldots \ldots \ldots \ldots \ldots \ldots \ldots \ldots \ldots \ldots \ldots \ldots \ldots \ldots \ldots \ldots \ldots \ldots \ldots . . \ldots \ldots \ldots$ 
5.1.10 Federal, State, Regional and Local Land Use Programs .................................... 5-8

5.1 .11 Noise $\ldots \ldots \ldots \ldots \ldots \ldots \ldots \ldots \ldots \ldots \ldots \ldots \ldots \ldots \ldots \ldots \ldots \ldots \ldots \ldots$

5.2 Accidents During Drilling and Operation ................... 5-8

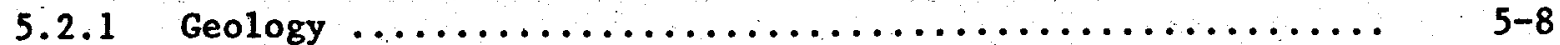

5.2.2 Physiography and Soils ....................... 5-9

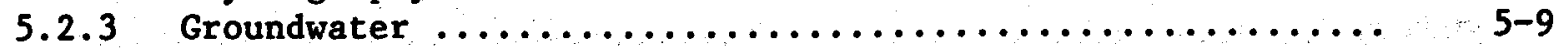

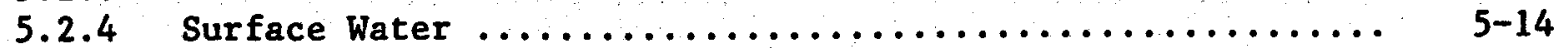

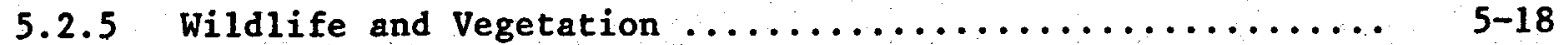

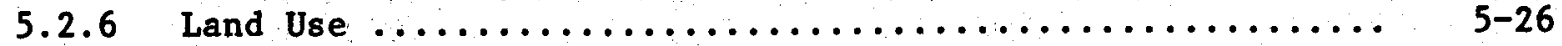

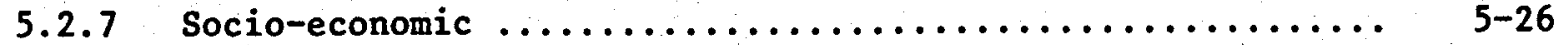

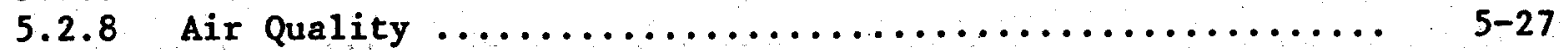

5.2.9 Recreational, Archaeological and Historical 5-29

5.2.10 Federal, State, Regional and Local Land Use

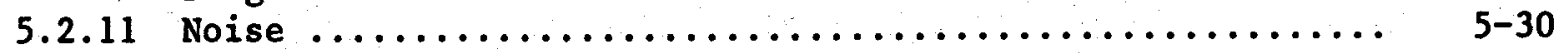

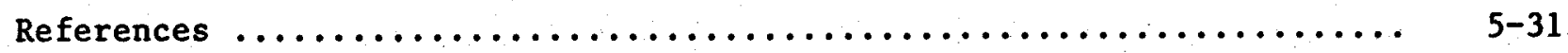

CHAPTER SIX - COORDINATION WITH FEDERAL, STATE, REGIONAL, AND

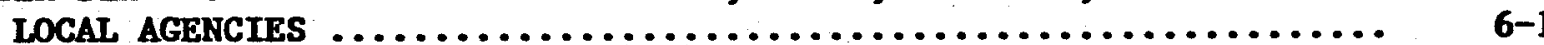

6.1 Programs and Permits $\ldots \ldots \ldots \ldots \ldots \ldots \ldots \ldots \ldots \ldots \ldots \ldots \ldots \ldots \ldots \ldots \ldots$ 6-1

$6.1 .1 \quad$ Federal $\ldots \ldots \ldots \ldots \ldots \ldots \ldots \ldots \ldots \ldots \ldots \ldots \ldots \ldots \ldots \ldots \ldots \ldots \ldots$

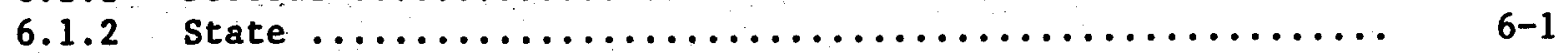

6.1 .3 Regional and Local $\ldots \ldots \ldots \ldots \ldots \ldots \ldots \ldots \ldots \ldots \ldots \ldots \ldots \ldots \ldots$

6.2 Land Use Plans $\ldots \ldots \ldots \ldots \ldots \ldots \ldots \ldots \ldots \ldots \ldots \ldots \ldots \ldots \ldots \ldots \ldots \ldots \ldots \ldots \ldots$

$6.2 .1 \quad$ Federal $\ldots \ldots \ldots \ldots \ldots \ldots \ldots \ldots \ldots \ldots \ldots \ldots \ldots \ldots \ldots \ldots \ldots \ldots \ldots$

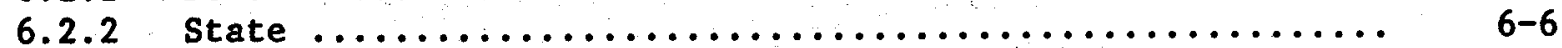

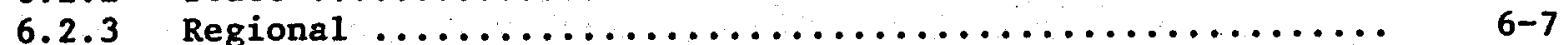

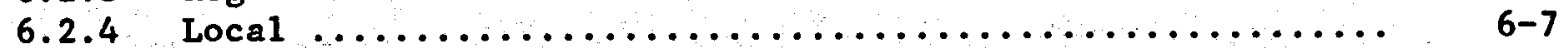

References $. \ldots \ldots \ldots \ldots \ldots \ldots \ldots \ldots \ldots \ldots \ldots \ldots \ldots \ldots \ldots \ldots \ldots \ldots \ldots \ldots \ldots, 6,8$

CHAPTER SEVEN - ALTERMATIVES $\ldots \ldots \ldots \ldots \ldots \ldots \ldots \ldots \ldots \ldots \ldots \ldots \ldots \ldots \ldots$ 7-1

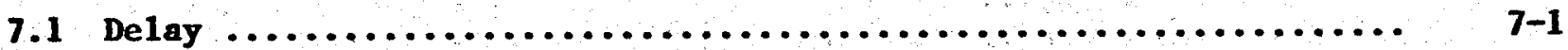

7.2 No Build $\ldots \ldots \ldots \ldots \ldots \ldots \ldots \ldots \ldots \ldots \ldots \ldots \ldots \ldots \ldots \ldots \ldots \ldots \ldots \ldots \ldots \ldots \ldots \ldots$

7.3 Alternative Approaches $\ldots \ldots \ldots \ldots \ldots \ldots \ldots \ldots \ldots \ldots \ldots \ldots \ldots \ldots \ldots \ldots \ldots$ 7-1 
7.4 Alternative sites $\ldots \ldots \ldots \ldots \ldots \ldots \ldots \ldots \ldots \ldots \ldots \ldots \ldots \ldots \ldots \ldots \ldots \ldots \ldots \ldots \quad 7-2$

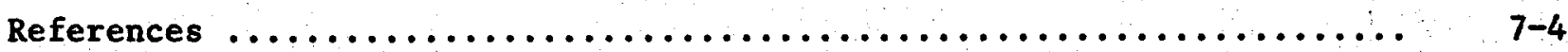

APPENDIX $\mathbf{A} \ldots \ldots \ldots \ldots \ldots \ldots \ldots \ldots \ldots \ldots \ldots \ldots \ldots \ldots \ldots \ldots \ldots \ldots \ldots \ldots \ldots \ldots \ldots, \Delta-1$

APPENDIX B $\ldots \ldots \ldots \ldots \ldots \ldots \ldots \ldots \ldots \ldots \ldots \ldots \ldots \ldots \ldots \ldots \ldots \ldots \ldots \ldots \ldots \ldots \ldots \ldots \ldots$

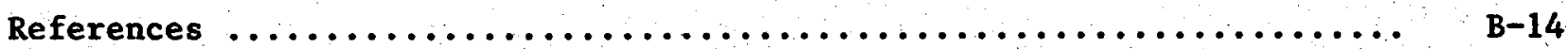

APPENDIX $\mathbf{c} \ldots \ldots \ldots \ldots \ldots \ldots \ldots \ldots \ldots \ldots \ldots \ldots \ldots \ldots \ldots \ldots \ldots \ldots \ldots \ldots \ldots \ldots \ldots \ldots, c \ldots$ 
1-1 Aquifers Identified in Monterey M.0. Miller No. 1, Section 27, T15S, RSW, Cameron Parish, Louisiana, which are available for potential disposal of geopressure brines produced during the testing activities .................. 1-14

1-2 Preliminary List of Parameters for which the Geopressured Water and Gas will be Analyzed ..................... 1-16

2-1 Geologic Column for the study Area $\ldots \ldots \ldots \ldots \ldots \ldots \ldots \ldots \ldots \ldots \ldots$

2-2 Estimated Net Porosity and Depth to Top of Geopressured Sands to be Penetrated and Tested by the Proposed Action ....... 2-8

2-3 Chemical analyses from water wells completed in the Chicot Aquifer, approximately $6.4 \mathrm{~km}(4 \mathrm{mi})$ northeast of the proposed well site ................................ 2-14

2-4 Initial Water Quality Assessment, Segments 05-E, : 05-F,

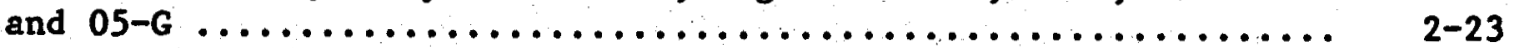

2-5 Water Quality Standards and Water Use Designations ......... 2-24

2-6 Common Sound Levels $\ldots \ldots \ldots \ldots \ldots \ldots \ldots \ldots \ldots \ldots \ldots \ldots \ldots \ldots \ldots \ldots \ldots$ 2-34

2-7 Permissible Noise Exposure Without Hearing Protection ........ 2-33

2-8 Levels of Environmental Noise ...................... 2-35

2-9 Noise Levels not to be Exceeded ...................... 2-36

2-10 Percent Frequency and Wind Speed for Stability Classes as Averaged between Taft, Louisiana and Houston, Texas ....... 2-40

2-11 Summary of Air Quality Data Observed in the Lake Charles Area as Compared to National Ambient Standards ............ 2-41

3-1 Hydrogen Sulfide Concentrations in the Frio Formation ........ 3-17

5-1 Summary of Water Analyses from Edna Delcambre Well ......... 5-2

5-2 Range of Concentrations Reported for Louisiana Geopressured

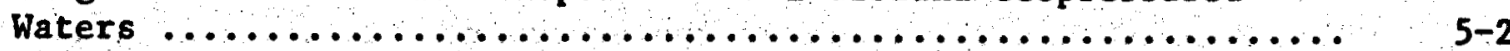

5-3 Typical Gas Analysis from Delcambre Test Well ............ 5-3

5-4 Chemical Composition of Geopressured Waters in South Central Louisiana ................................... $5-3$

5-5 Chemical Composition of Louisiana Geopressured Waters ....... 5-16 
5-6 Range of Relative Hazard of Known Geopressure Fluid

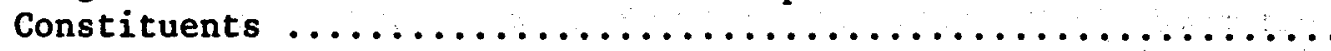

5-7 EPA Suggested Water Quality Criteria ................. 5-17

5-8 Constituents in Geopressured Brines of Environmental

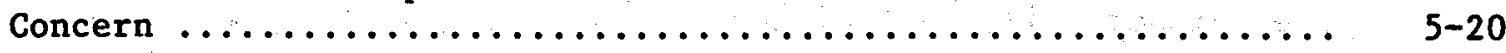

6-1 Matrix of Federal Action of Geopressured We11 Testing Activities and Related $0 i 1$ Activities ................... 6-2

6-2 Major Federal Legislation Pertaining to Valuable Resources .................................. $6-3$

6-3 Matrix of State Actions of Geopressured We11 Testing Activities and Related $0 i 1$ Activities ................... 6-4

6-4 Forms that must be Submitted in the State of Louisiana for the Drilling and Production of Geopressured Resources ...... 6-5

B-1 Plant Species Observed Within the Impounded Marsh in the

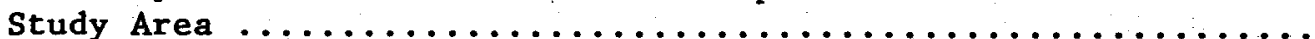

B-2 Plant Species Observed on Plant Road and Spoil Banks Within Gladys McCal1 Proposed Well siťe .................. B-2

B-3 Plant Species Observed Along Highway 82, Within the Gladys McCall Study Area .......................... B-3

B-4 Mammal Species Which May Occur in the Chenier Plain Marshes of the Study Area $\ldots \ldots \ldots \ldots \ldots \ldots \ldots \ldots \ldots \ldots \ldots \ldots \ldots$ B

B-5 Bird Species Known to Nest on Spoil Banks in Rockefeller Wildlife Refuge, Cameron Parish, Louisiana .............. B-6

B-6 Bird Species Known to Nest in Intermediate Marshes in Rockefeller Wildlife Refuge, Cameron Parish, Louisiana ....... B B

B-7 Reptiles and Amphibians Which May Occur Within the Study Area $\ldots \ldots \ldots \ldots \ldots \ldots \ldots \ldots \ldots \ldots \ldots \ldots \ldots \ldots \ldots \ldots \ldots \ldots, \quad$ B-8

B-8 Fish Species That May Occur in the Study Area .............. B-10

B-9 Waterfow1 Species Which May Occur in the study Area ......... B-13 
1-1 Location of the DOE Gladys McCa11 Proposed Well site in relation to the Gulf Coast Region ..................... 1-3

1-2 A topographic map of the DOE Gladys McCall Proposed Wel1 Site and Study Area $\ldots \ldots \ldots \ldots \ldots \ldots \ldots \ldots \ldots \ldots \ldots \ldots \ldots \ldots \ldots$. $1-6$

1-3 An aerial photograph of the DOE Gladys McCall Proposed Well Site and Study Area $\ldots \ldots \ldots \ldots \ldots \ldots \ldots \ldots \ldots \ldots \ldots \ldots \ldots \ldots \ldots . \ldots \ldots$

1-4 Schematic of access road to Gladys McCall well site ......... 1-10

1-5 Schematic plan of access road and Gladys McCall well site ..... 1-12

1-6 Schematic section of protection levee and well pad at Gladys McCall well site .......................... 1-13

2-1 Gulf coast geosyncline: approximate thickness of the Cenozoic of Louisiana $\ldots \ldots \ldots \ldots \ldots \ldots \ldots \ldots \ldots \ldots \ldots \ldots \ldots \ldots \ldots$ 2-3

2-2 Top of the geopressured zone beneath the region ........... 2-6

2-3 Top of the geopressured zone beneath the study area ........ 2-7

2-4 Groundwater quality/depth relationship in the Chicot

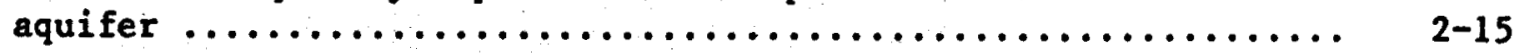

2-5 Surface water features and generalized water movement

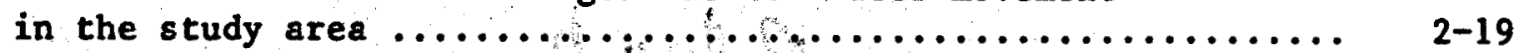

2-6 Isohaline map of the Louisiana coast $\ldots \ldots \ldots \ldots \ldots \ldots \ldots \ldots \ldots \ldots . \ldots 22$

2-7 Vegetation of the study area $\ldots \ldots \ldots \ldots \ldots \ldots \ldots \ldots \ldots \ldots \ldots \ldots \ldots . . \ldots 27$

2-8 Recreational and wildlife management areas and range of
the red wolf in relation to the study area $\ldots \ldots \ldots \ldots \ldots \ldots \ldots \ldots$

2-9 Land use map of the study area $\ldots \ldots \ldots \ldots \ldots \ldots \ldots \ldots \ldots \ldots \ldots \ldots \ldots \ldots$

3-1 Noise contours resulting from normal operation of a

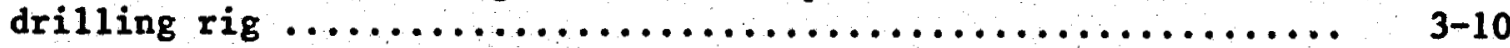


DOE Gladys McCa11 proposed well site

Rockefeller Refuge Prime Prospect Area

A-F/yr

$A-F / \mathrm{mi}^{2}$

ac

BPD

cfs

cu mi.

dBA

ERDA

DOE

DOI

gal/da

$\mathrm{g} / \mathrm{ml}$

ICRPDC

JTU

$\mathrm{kg} / \mathrm{day}$

$\mathrm{kg} / \mathrm{hr}$

LDOTD

Ldn

Leq

1/day

$1 \mathrm{bs} / \mathrm{da}$

MCF

md

$\mathrm{mg} / 1$

$\mathrm{mg} / \mathrm{m}^{3}$
The 5 acre area on which support facilities, including separators, cooling towers, tanks and laboratories will be located; includes point of drilling.

An irregular-shaped area $64 \mathrm{~km}$ (40 mi) southeast of Lake Charles, La. This area is considered by DOE to be the most desirable zone for geopressured-geothermal exploration and development at this time.

acre-feet per year

acre-feet per square mile

acre

barrels per day

cubic feet per second

cubic mile

A-weighted sound levels taken with a sound level meter and expressed as decibels on the scale. The "A" scale approximates the frequency response of the human ear.

Energy Research and Development Administration

Department of Energy

Department of Interior

gallons per day

grams per mililiter

Imperial Calcasieu Regional Planning and Development Commission

Jackson Turbidity Units

kilograms per day

kilograms per hour

Louisiana Department of Transportation and Development

day/night noise level

equivalent sound level

liters per day

pounds per day

thousand cubic feet

millidarcy

milligrams per liter

milligrams per cubic meter 
m1

MPN

$\mathrm{m} / \mathrm{s}$

$\mathrm{m}^{3} / \mathrm{s}$

$\mu \mathrm{g} / \mathrm{m}^{3}$

OSHA

PARC

ppb

$\mathrm{ppm}$

ppt

psi

SCS

Tcf

TDS mililiter

Most Probable Number

meters per second

cubic meters per second

micrograms per cubic meter

Occupational Safety and Health Act

Public Affairs Research Council

parts pex billion

parts per million

parts per thousand

pounds per square inch

Soil Conservation Service

trillions of cubic feet

total dissolved solids 
SUMMARY

This environmental assessment (EA) has been prepared in compliance with the requirements of the National Environmental Policy Act (NEPA) of 1969 and Executive Orders 11988 Floodplain Management and 11990 Protection of Wetlands. The assessment addresses the expected impacts of drilling and testing a geopressure design well as part of the Geopressure Subprogram of the DOE Division of Geothermal Energy (DGE). The Geopressure Subprogram is one of several subprograms developed and implemented by DOE for fulfilling its legislative mandate to pursue a National Geothermal Energy Research, Development, and Demonstration Program.

The proposed action consists of drilling one geopressured-geothermal resource fluid well for testing over a three-year period. Originally, the Gladys McCall well test was to be conducted as a well of opportunity (i.e., re-entry into an abandoned oil and/or gas well), and the potential environmental impacts of the project were analyzed based on the Gulf Coast Well Testing, Frio Formation, Texas and Louisiana, Environmental Assessment (DOE/EA-0023, 1978). However, re-entry of the well was not possible and the Department of Energy (DOE) was forced to plug and abandon the well prior to flow testing the geopressured resource. The Division of Geothermal Energy (DGE-DOE) commissioned a feasibility study for a design well at the site using the existing access road and well site and placing the new well adjacent to the original well of opportunity in Cameron Parish, Louisiana. The proposal was evaluated 
based on technical, financial, managerial, and environmental criteria and a site and contractor were selected for implementation pending completion of a site-specific environmental analysis. This EA was prepared to fulfill that requirement.

The proposed action will consist of drilling one geopressured-geothermal resource fluid well for intermittent production testing over the first year of the test. During the next two years, long-term testing of 40,000 BPD will be flowed. A number of scenarios may be implemented, but it is felt that the total fluid production will approximate 50 million barrels. The test well will be drilled with a $22 \mathrm{~cm}(8.75 \mathrm{in})$ borehole to a total depth of approximately $5185 \mathrm{~m}(17,000 \mathrm{ft})$. Up to four disposal wells will provide disposal of the fluid from the designated 40,000 BPD test rate. The original Gladys McCa11 well and an existing disposal well will be used as two of the disposal wells. Up to two additional wells will be drilled if required.

All surface facilities will be within the existing levee system. Extensive tests will be conducted on the physical and chemical composition of the fluids, their temperature, the nature of the flow, fluid disposal techniques, and the rellability and performance of equipment. The objective of the proposed action is to determine the economic viability of the geopressured resource. 
The study area for the well site is on Recent coastal wetlands of the Louisiana coastal zone in Cameron Parish in southwest Louisiana. Surface hydrology in this wetland system of low elevation and low relief is modified by the levees and canals excavated by the petroleum industry. Groundwater is used for domestic supplies in selected areas. Wildife and natural habitat are the dominant uses of the Recent coastal wetlands.

The well site is at the end of an existing board road, $3.7 \mathrm{~km}(2.3 \mathrm{mi})$ south of Louisiana State Highway 82. Residential and commercial development are restricted to the Grand Cheniere Ridge, a stranded beach ridge which Louisiana 82 follows. The headquarters of the Rockefeller Wildiife Refuge and Game Preserve are $6.4 \mathrm{~km}(4 \mathrm{mi})$ northeast of the well site and the Refuge extends to the east. There are no known archeological sites in the study area. No known historic or National Register of Historic Places sites are in the study area.

Construction of the proposed action will not change the land use around the well site. During operation of the well test, the only expected impacts are from venting of gases or flaring of gases and noise. No environmental impacts are expected on the Rockefeller Wildlife Refuge. After the tests are completed, the wells will be plugged and abandoned in accordance with Louisiana office of Conservation regulations. All surface facilities and equipment will be removed from the site and the site will be restored as much as possible to its original contour. All wastes which cannot be reinjected will be collected and disposed of in a landfill operated in accordance with applicable local, state, 
and Federal regulations. Because of its location on a floodplain, there is a potential that flooding from a storm-surge could inundate the area and wash pollutants into the surrounding wetland system before this can be accomplished.

Accidents may result from this proposed action. However, numerous safeguards will be installed to reduce the probability of such an occurrence. If a blowout should occur, the adjacent wetlands may be polluted. Surface water may be contaminated by the geopressured brines. Vegetation and possibly some wildlife will be destroyed. Depending on the severity of the accident and the extent of impact, homes, business, and public facilities may have to be evacuated. The air quality around the well site may contain harmful gases such as $\mathrm{H}_{2} \mathrm{~S}$ if these are present in the production waters. 


\section{REFERENCES}

U.S. Department of Energy

1978 Environmental assessment, geothermal energy geopressure subprogram, Gulf Coast well testing activity, Frio Formation, Texas and Louisiana. DOE/EA 0023.

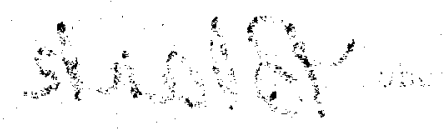

1 
Blank

$$
5-6
$$


CHAPTER ONE - DESCRIPTION OF THE PROPOSED ACTION

\subsection{Introduction}

This EA addresses the expected potential impacts of drilling and testing a geopressure design well as part of the Geopressure Subprogram of the DGE. The goal of the Geopressure Subprogram is to stimulate development of geopressured resources as an economic, reliable, operationally safe, and environmentally acceptable energy source. The subprogram includes activities in the areas of engineering research and development; resource exploration, assessment, and development; resource utilization, including pilot and demonstration facilities; and environmental research and control technology development. It should be recognized that most of the subprogram activities extend over several years and are presently in their early stages of implementation.

The zones of potential geopressure development are in the region located along the Texas and Louisiana Gulf Coasts extending up to $300 \mathrm{~km}(200 \mathrm{mi})$ iniand. Geopressured zones are sedimentary basins where water is trapped at high pressures within or below thick, nearly impermeable shale sequences. The confined water supports most or all of the weight of the overburden, inhibiting sediment compaction and causing formation pore pressure to exceed hydrostatic pressure. In sedimentary basins that are underlain by thin oceanic crust, upward thermal conduction from the mantle heats geopressured fluids and sediments to abnormally high temperatures, often in excess of $260^{\circ} \mathrm{C}\left(500^{\circ} \mathrm{F}\right)$. 
The fluid resource base, the potential recoverable energy within the geopressured zones, consists of three major forms: water at high temperatures, water at high pressures, and dissolved natural gas.

Originally, the Gladys McCall well test project was to be included under the Wells of Opportunity (woo) Program. At that time, an evaluation of the environmental effects of the project was conducted based on Gulf Coast Well Testing Activity, Frio Formation, Texas and Louisiana, Environmental Assessment (DOE/EA-0023, 1978). However, when re-entry was attempted; the operator discovered that the upper string of casing had been removed and DOE was forced to plug and abandon the well prior to flow testing the geopressured resource. Subsequently, the Division of Geothermal Energy (DGE-DOE) commissioned a feasibility study for a design well at the site because the extent and thickness of the sand (and other technical factors) made the prospect appear very good. DGE-DOE received a proposal to drill, test, and evaluate a geopressured test well adjacent to the original well of opportunity in Cameron Parish, Louisiana. The project was evaluated based on technical, financial, and managerial criteria and was selected for implementation as a design well pending completion of a site specific environmental analysis. This EA was prepared to fulfill that requirement.

This Environmental Assessment (EA) has been prepared to assess the environmental implications of the DOE's proposal to drill, complete, and test one geopressure we 11 located in Cameron Parish, Louisiana, on an existing well site $64 \mathrm{~km}(40 \mathrm{mi})$ southeast of Lake Charles, Louisiana (Figure 1-1). The test well is herein referred to as DOE 


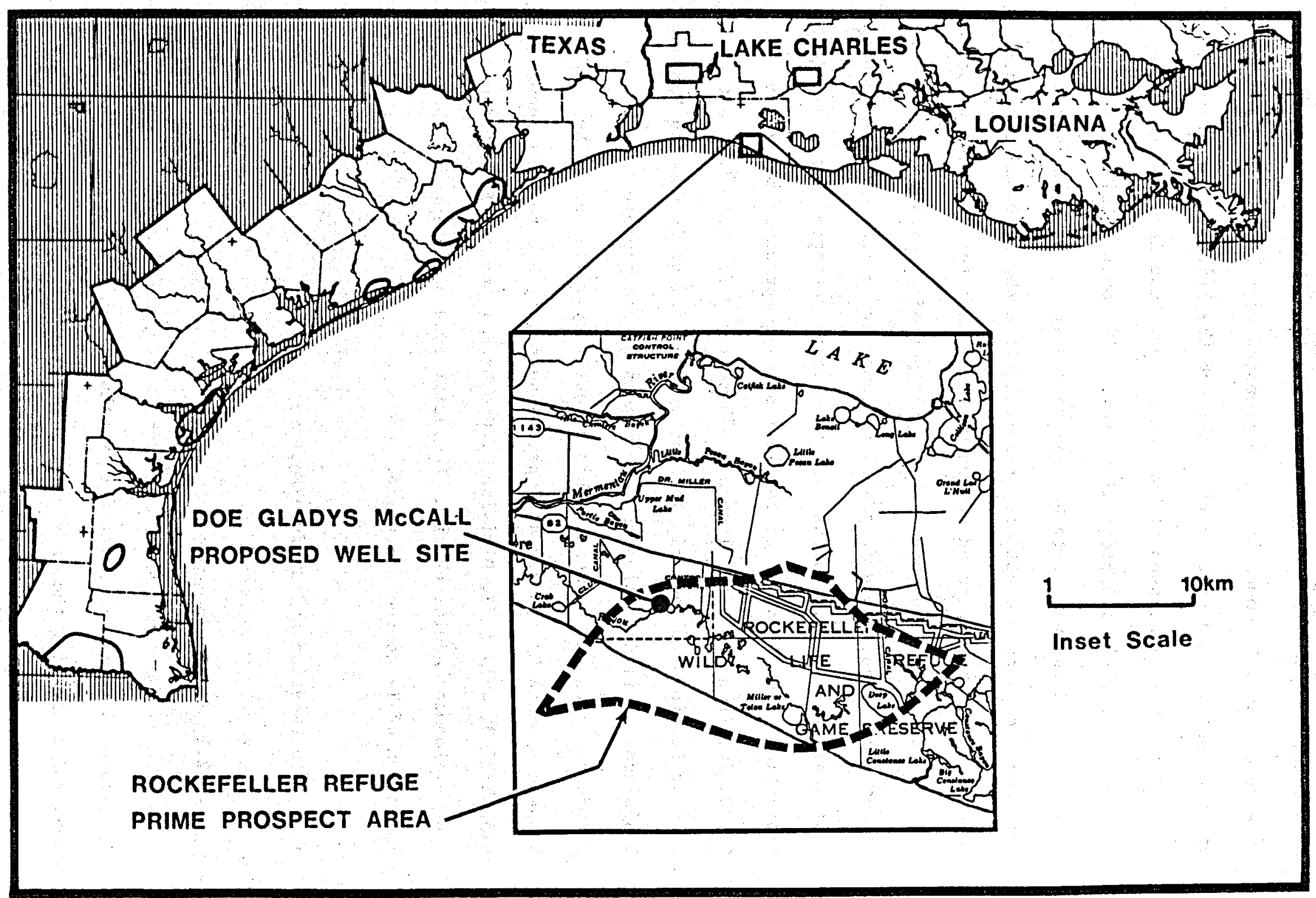

Figure 1-1. Location of the DOE Gladys McCall Proposed Well Site in relation to the Gulf Coast Region (After DOE, 1979 and Newchurch et al, 1978.) 
Gladys McCall. One or more disposal wells (as necessary) will be located on the site compound of the proposed test well. The DOE proposes to operate the test facility through the primary contrator, Technadril-Fenix \& Scisson of Houston, Texas. The State of Louisiana, through the Louisiana Geological Survey, will monitor noise and air quality around the well site and maintain a grid system to detect subsidence or tectonic activity resulting from the proposed action (Appendix A). The proposed action will evaluate the geopressure potential of the subsurface over a three-year period. Tests to be conducted inlude flow rates, fluid composition, temperature, gas content, geological characteristics, and the land subsidence potential for subsequent production. The location of the well site is approximately $702 \mathrm{~m}$ $(2,300 \mathrm{ft})$ from the north line and $458 \mathrm{~m}(1,500 \mathrm{ft})$ from the east line of Section 27, Township 15 South, Range 5 west in Cameron Parish, Louisiana. This EA evaluates the impacts of the proposed action on the surrounding environment. This EA activity falls under the broad subprogrammatic Environmental Impact Assessment, Geopressure Subprogram, EIA/GE/77-3, July 1977, Division of Geothermal Energy, Energy Research and Development Administration, the activity associated with the Frio Formation of Texas and Louisiana.

\subsection{Site Location and Surface Features}

\subsubsection{The Region}

The proposed action is located in southwest Louisiana in a promising zone for evaluating the physical and chemical characteristics of the 
resource, a prime prospect (Figures 1-1, 1-2, and 1-3). Prime prospects in Louisiana were identified by the Louisiana Geological Survey and the Louisiana State University based on geological and technical criteria. The well will be drilled into the Frio formation to a total depth of approximately $5,185 \mathrm{~m}(17,000 \mathrm{ft})$. Total net sand thickness in this area varies on the order of $229 \mathrm{~m}$ to $458 \mathrm{~m}$ (750 ft to $1500 \mathrm{ft})$.

\subsubsection{Site Selection}

The Rockefeller Prime Prospect (see "Chapter 7-Alternatives") and Gladys McCall well site were selected for resource analysis for a number of reasons:

1) the Gladys McCall well site is within the Rockefeller Refuge Prime Prospect Area, as defined by Hawkins (1977);

2) initial indications are that sand thickness, temperature, and permeability are suitable for characterizing the resource;

3) the direct environmental impact of the project will be minimal because of the existing plank road and original well site area; and

4) the nearest residential and commercial developments are $3.7 \mathrm{~km}(2.3 \mathrm{mi})$ away.

A preliminary environmental analysis was conducted prior to initiation of the original well of opportunity activities. This information was considered in the design well site selection process. As previously stated, the preliminary analysis concluded the environmental 

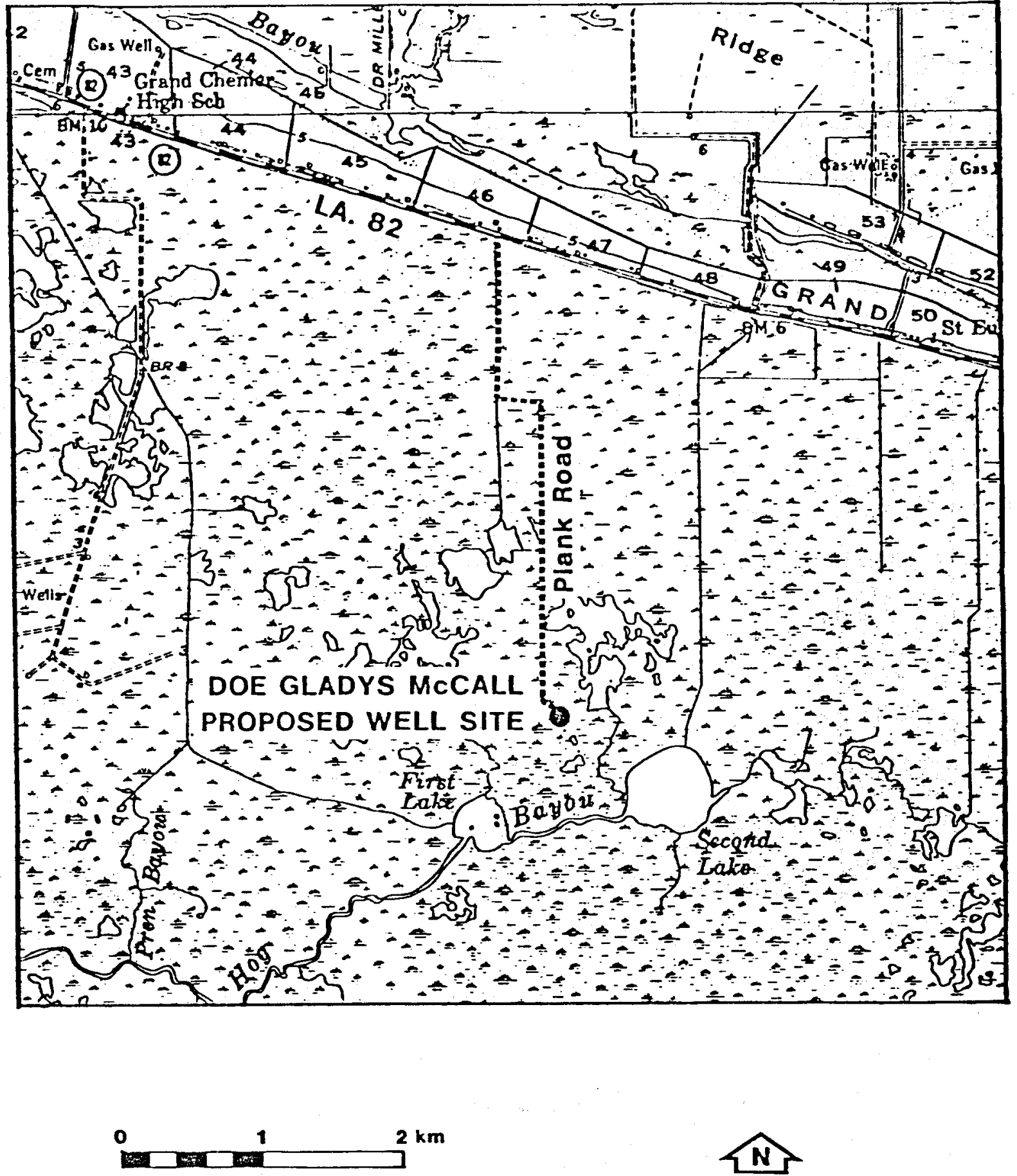

Figure 1-2. A topographic map of the DOE Gladys McCall Proposed Well Site and Study Area (USGS 15' quadrangles, Hog Bayou, Louisiana, 1955, and Grand Lake West, Louisiana, 1955). 

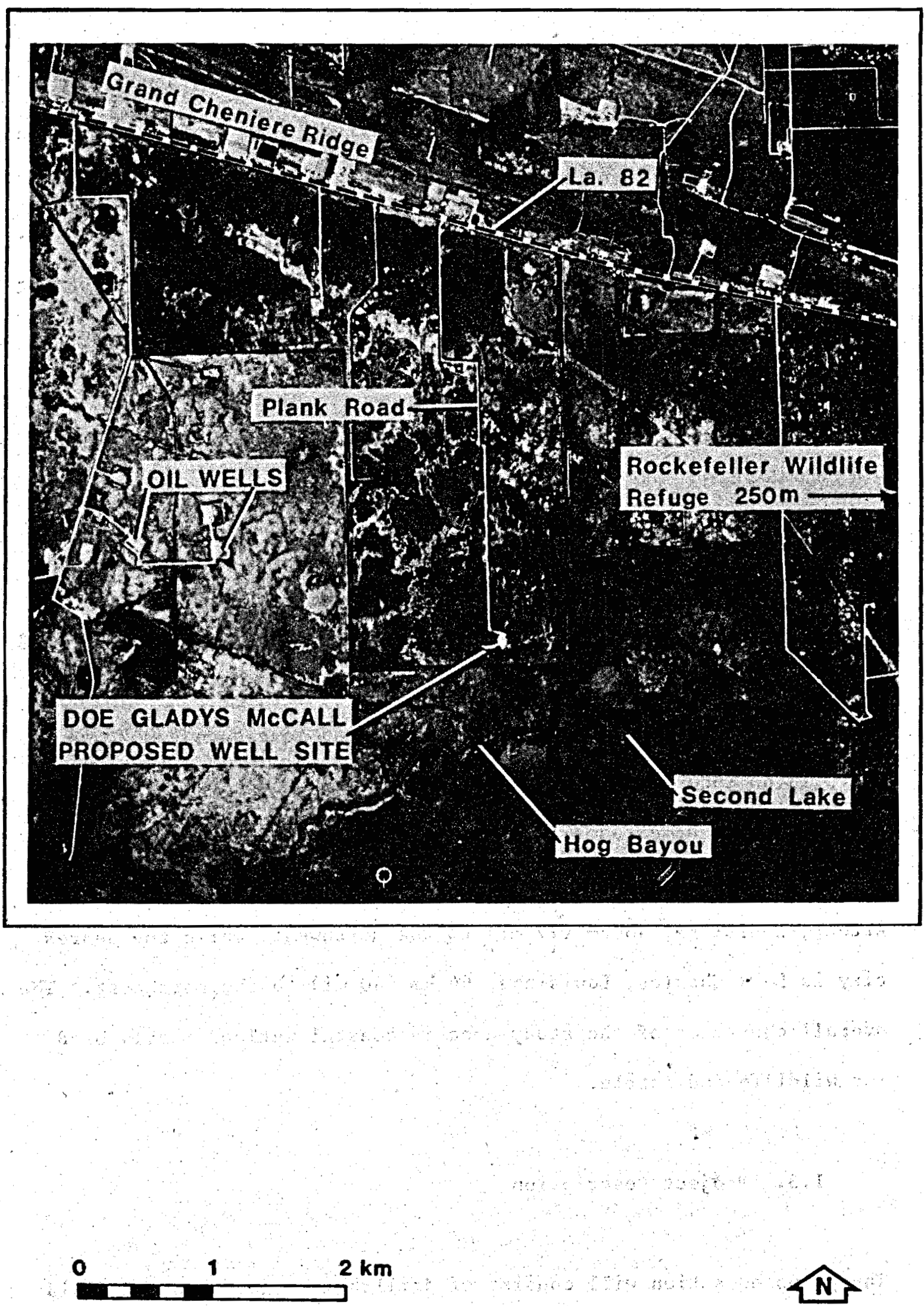

Figure 1-3. An aerial photograph of the DOE Gladys McCall Proposed Well Site and Study Area (Color IR, BIN No. 5232, Unit No. 1, Frame No. 9926, Image 'ID 578002691ROLL). 
effects of the project would be minor because surface disturbance and well drilling activities had already occurred. The proposed location of the design well is on an area which has already been disturbed by previous site activities. Unless another existing well site is used, alternate sites in the prime prospect area would require constructing a new well pad and providing access on undisturbed wetlands areas.

1.2.3. Description of the Proposed Well Site and Study Area

All development of surface facilities and injection wells will take place within the existing levees of the original well site. All of the land to be used for the project is in private ownership. Leasing agreements with the appropriate landowners are now being pursued. The well site is at latitude $29043^{\prime}$ north and longitude $92052^{\circ}$ 'west. There is no incorporated community within the study area; however a linear settlement extends along the Grand Cheniere Ridge $3.7 \mathrm{~km}$ (2.3 mi) north of the well site. The nearest large town is lake Arthur, Louisiana, $43 \mathrm{~km}(27 \mathrm{mi})$ to the northwest, while the nearest city is Lake Charles, Louisiana, $64 \mathrm{~km}$ ( $40 \mathrm{mi}$ ) to the northwest. The overall character of the study area is coastal wetland mostly used for wildife and cattle.

\subsection{Project Description}

The proposed action will consist of drilling one geopressured fluid well for production testing and one or more injection wells as necessary. A test well will be drilled with a $22 \mathrm{~cm}(8.75 \mathrm{in})$, or smaller, 
borehole to a total depth of approximately $5,185 \mathrm{~m}(17,000 \mathrm{ft})$. An existing disposal well will be deepened to provide disposal of lower volume fluids produced during initial testing. Although unsuitable for use as a test well, the existing Gladys McCall well will be reentered and used as a disposal well for the high volume test fluids. If necessary two new wells will be drilled to provide additional disposal capacity. The U.S. Environmental Protection Agency (EPA) Underground Injection Control Program (UIC) proposed rules apply to both geothermal and Injection wells and will be complied with once they become effective. Required surface facilites will be constructed and Installed on the existing well site in order to conduct the extensive resource test. Surface facilites include power supply, pipe racks, a mud pit, a cooling device, fuel tanks, and temporary structures for offices, locker rooms, and storage areas. Over a three year period the tests will assess the economic viability of the geopressure resource.

\subsubsection{Construction and Drilling}

The construction phase of the proposed action includes site and access preparation. Drilling includes both well drilling and testing.

\subsubsection{Site and Access Preparation}

The DOE Gladys McCall well site is accessible via an existing board road: a thoroughfare of alternating layers of rough cut planks on top of a dirt fill (FIgure 1-4). Installation of the road was for the original Gladys McCall well. The original well was used for oll and gas exploration. It was plugged and abandoned in 1970. Re-entry operations were started in early November 1978, and terminated in 


\section{GLADYS MCCALL ROAD BED DETAIL}

\section{Section $A A^{\circ}$ Stralght Away Run \\ Section BB' By-Pas8, Wings, and Turn-Ins}

All material dug by dragline from alongside roaduay as lajd out.

Katerial is marsh soil, sand, and blue clay.

Roadway Section $A A^{\prime}$

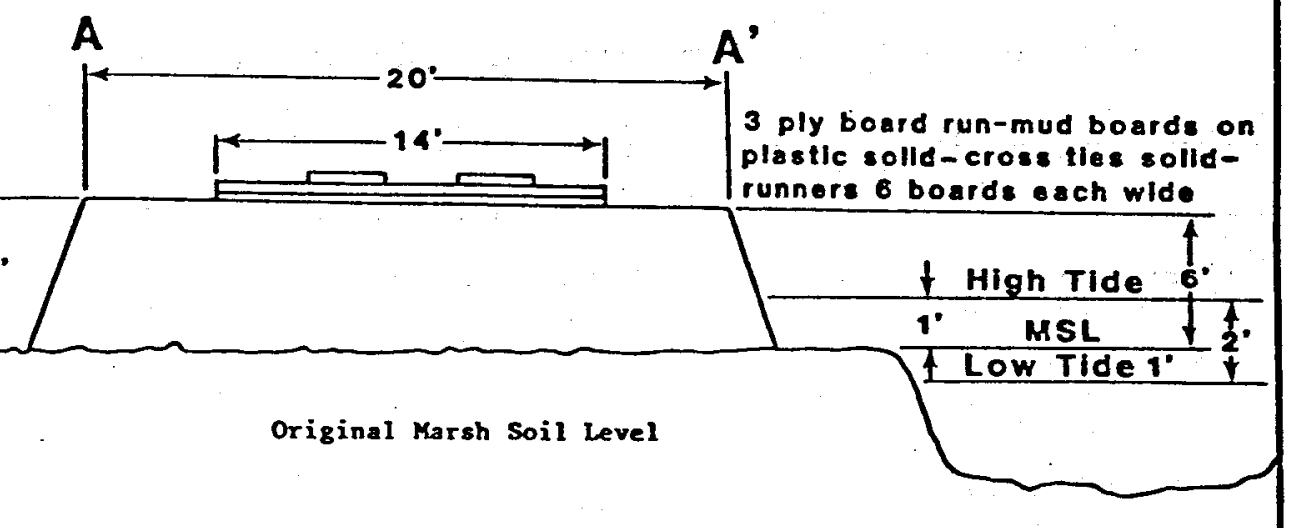

Roadway Section BB'

All dimensions of elevations and tides same as $M$ '

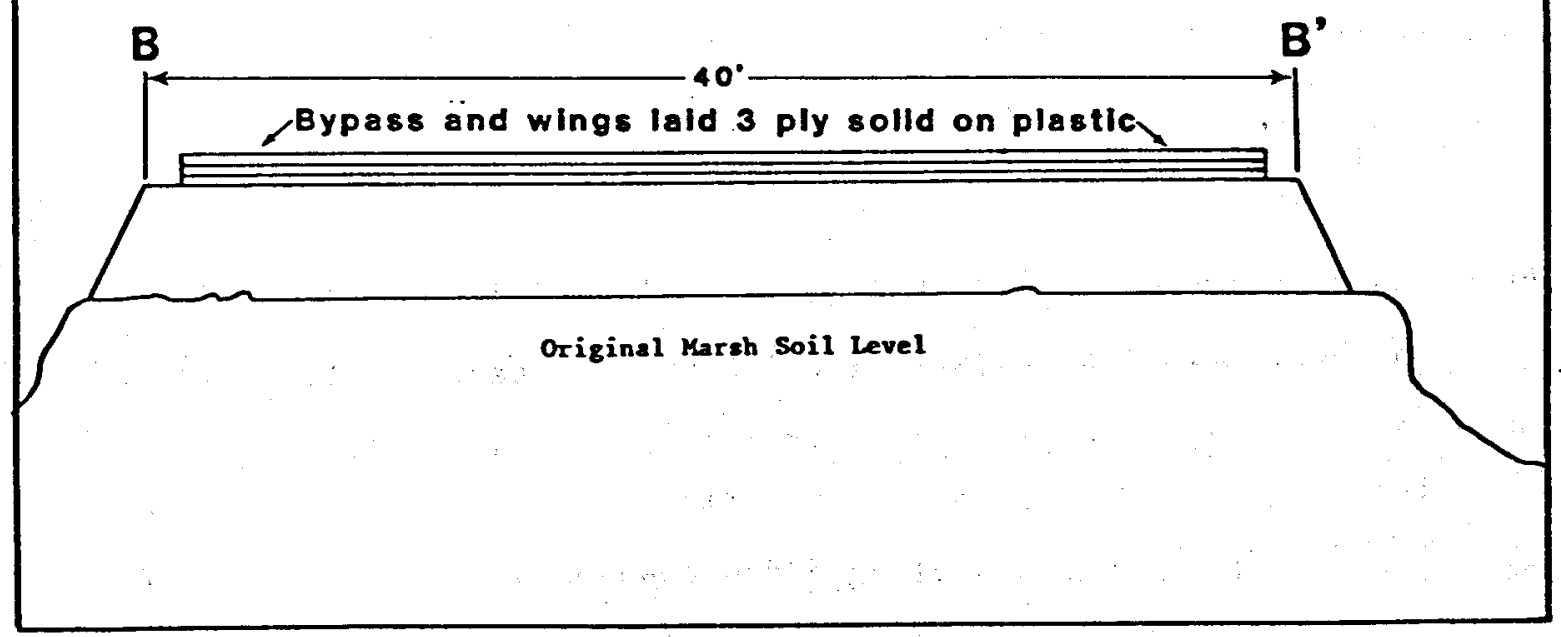

Figure 1-4. Schematic of access road to Gladys McCall well site. 
mid-December 1978, as a result of the inability to engage and replace the $18 \mathrm{~cm}$ ( $7 \mathrm{in}$ ) protection casing which had been severed with explosives. The road will be upgraded with boards and plastic to provide allweather access. The ariginal Gladys McCall well site will not be enlarged (Figures $1-5$ and 1-6) to accommodate the test well and facilities. An existing $r$ ing levee will be upgraded using materials available from within the well site. The land on the inside of the levee will be sloped toward the levee, establishing a drainage system for the well site. Fluids contained within the diked area (e.g., spills, runoff, and seepage) will be pumped to a lined pit for storage.

\subsubsection{Well Drilling and Testing}

Figure 1-5 shows the well site for the proposed test wel1. The test program will be drilled, cored, logged, and tested by TechnadrilFenix \& Scisson of Houston, Texas.

The casinghead and tubinghead are of conventional design except for the use of high-temperature sealing elements. The surface safety valve is designed to shut the well in automatically should any downstream line break or cut out with sand. It will also shut in if pressures increase above a predetermined value which will cause operational failure and result in an uncontrolled discharge of fluids into the environment.

Disposal wells will be drilled within the same ring levee as the test wel1. Table 1-1 1ists the aquifers which are available for potential 


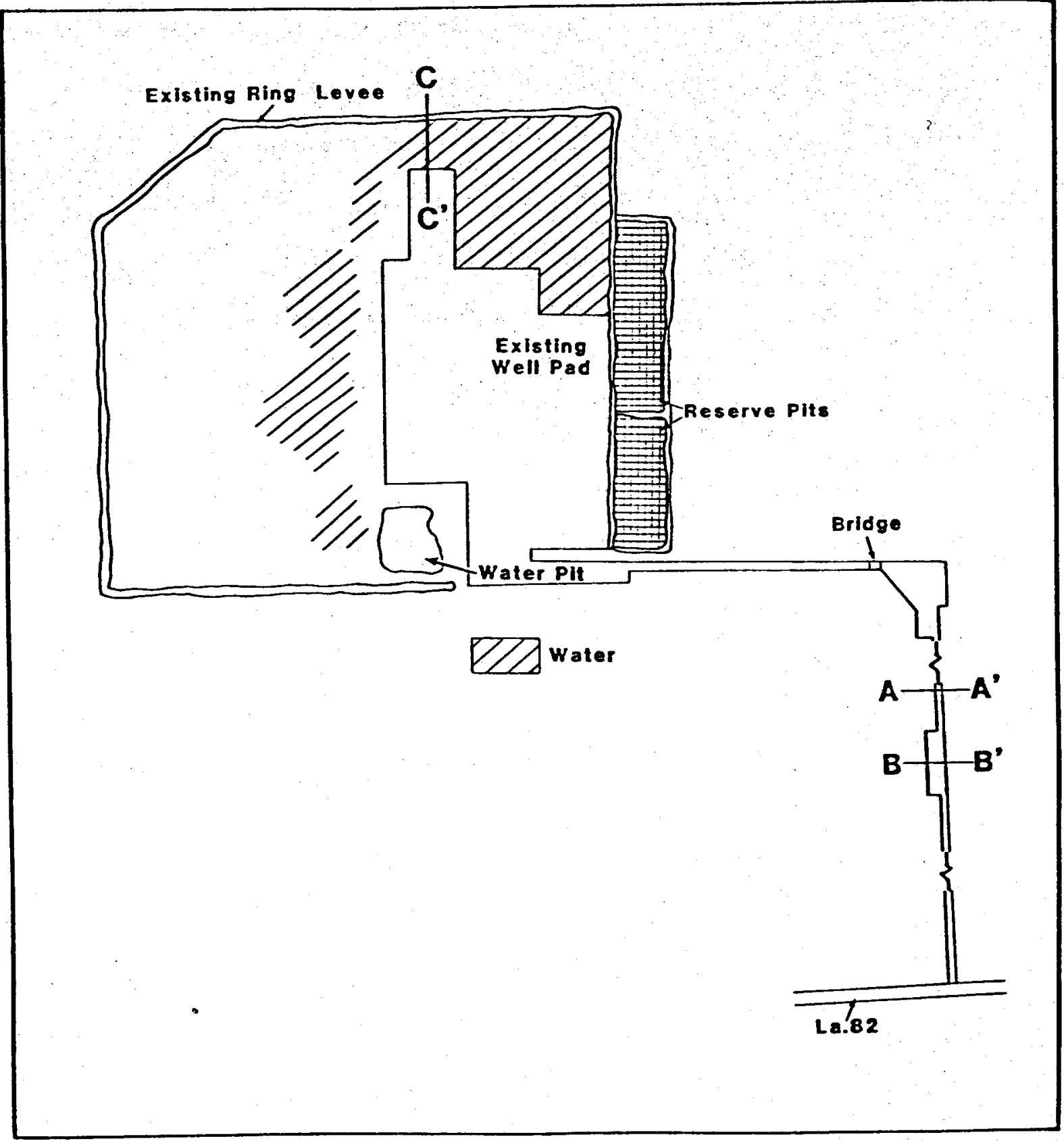

Figure 1-5. Schematic plan of access road and Gladys McCall well site. 


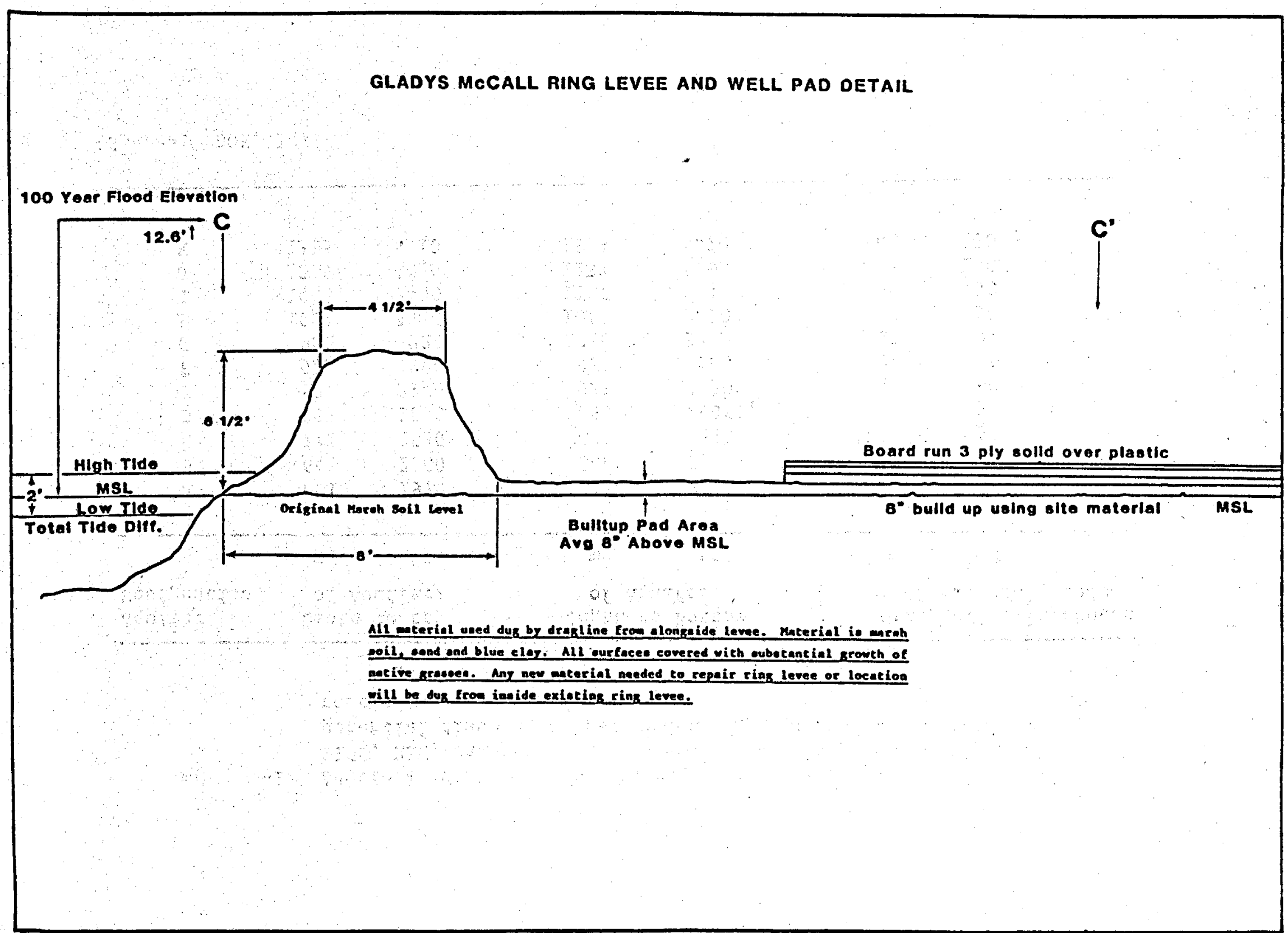

Figure 1-6. Schematic section of protection levee and well pad at Gladys McCall well site. 
Table 1-1. Aquifers Identifled In Monterey M.0. Miller No. 1, Section 27, T15S, RSW, Cameron Parish, Loulsiana, which are avallable for potentlal disposal of geopressure brines produced during the testing activities.

\begin{tabular}{|c|c|c|c|c|c|c|}
\hline \multirow[t]{2}{*}{$\begin{array}{l}\text { Aquifer } \\
\text { Designation }\end{array}$} & \multicolumn{2}{|c|}{$\begin{array}{l}\text { Depth to top } \\
\text { of Aquifer }\end{array}$} & \multicolumn{2}{|c|}{$\begin{array}{l}\text { Depth to Bottom } \\
\text { of Aquifer }\end{array}$} & \multicolumn{2}{|c|}{$\begin{array}{c}\text { Net Aquifer Thickness } \\
\text { of Disposal Sands }\end{array}$} \\
\hline & $\mathrm{m}$ & $\mathrm{ft}$ & $\mathrm{m}$ & ft & $\mathrm{m}$ & ft \\
\hline $\begin{array}{l}A \\
B \\
C \\
D \\
E \\
F \\
G \\
H \\
I \\
J \\
K\end{array}$ & $\begin{array}{r}601 \\
641 \\
772 \\
857 \\
897 \\
933 \\
932 \\
1022 \\
1064 \\
1229 \\
1315\end{array}$ & $\begin{array}{l}1970 \\
2100 \\
2530 \\
2810 \\
2940 \\
3060 \\
3220 \\
3350 \\
3490 \\
4030 \\
4310\end{array}$ & $\begin{array}{r}616 \\
666 \\
802 \\
880 \\
921 \\
964 \\
1016 \\
1040 \\
1107 \\
1283 \\
1363\end{array}$ & $\begin{array}{l}2020 \\
2185 \\
2630 \\
2885 \\
3020 \\
3160 \\
3330 \\
3410 \\
3630 \\
4205 \\
4470\end{array}$ & $\begin{array}{l}14 \\
21 \\
29 \\
11 \\
18 \\
26 \\
27 \\
15 \\
40 \\
43 \\
40\end{array}$ & $\begin{array}{r}45 \\
70 \\
95 \\
35 \\
60 \\
85 \\
90 \\
50 \\
130 \\
140 \\
130\end{array}$ \\
\hline
\end{tabular}

Source: DOE, 1979 
disposal of geopressure brines produced during the testing activities. Disposal well No. 1, the existing disposal we11, will be deepened to $857 \mathrm{~m}(2,810 \mathrm{ft})$. Although unsuitable for use as the test well, the original Gladys McCall well w111 be cleaned and then cemented at 1,052 m $(3,448 \mathrm{ft})$ for use as a disposal well. The casing w111 be perforated at selected intervals for geopressure fluid disposal. If required two additional wells will be drilled to the required depths (approximately $1,373 \mathrm{~m}[4,500 \mathrm{ft}])$.

Power for the test site will be supplied by the drilling rig and aux1liary generators. After removing the $\mathrm{rig}$, power will be from either generators or an extension from the powerline serving Grand Cheniere, approximately $4.8 \mathrm{~km}(3 \mathrm{mI})$ long. Potable water w111 be hauled to the site by truck. Water supplies for drilling fluids, cement, and general cleanup will be pumped from canals and bayous near the site. The mud pits will be emptied into the disposal wells after drilling is completed, if practical. Otherwise the residue will be hauled to an approved waste disposal site. Table 1-2 shows the chemical parameters to be analyzed during the test program.

Flow testing consists of two distinct phases: the Initial short-term tests and the high volume long-term tests. Typically, the inftial short-term tests consist of a stepped pumping test beginning at a pumping rate of about 20,000 BPD for a period of 15 days. The rate is then Increased by an Increment of 10,000 BPD and pumped at that. rate for 15 days. The initial short-term tests last 60 days with a final pumping rate of $40,000 \mathrm{BPD}$. Typlcally, the high volume long-term 
Table 1-2. Preliminary List of Parameters for which the Geopressured Water and Gas will be Analyzed.

A. Metals
1. Copper
2. Zinc
3. Boron
4. Arsenic
5. Chromium
6. Mercury
7. Lead
8. Cadmium

B. Solids

1. Dissolved

2. Total

C. Hardness

1. Calcium carbonate

2. Magnesium carbonate

D. Others

1. Carbonate

2. Bicarbonate

3. Chloride

4. Iron

5. Sulfate

6. Dissolved silicate
A. Hydrocarbons (percent)
1. Methane
2. Ethane
3. Propane
4. Isobutane
5. Normal butane
6. Osopentane
7. Pentane
8. $\mathrm{C}_{6}+$

B. Other

1. Hydrogen sulfide

2. Carbon dioxide

3. Radon

4. He

5. $\mathrm{N}_{2}$

6. $\mathrm{O}_{2}$

Chemical Properties of Water

1. Density

2. Compressibility

3. Conductivity

4. Viscosity

5. $\mathrm{pH}$

Recombination Pressure, Volume, Temperature Analysis

1. Solution gas-water ratio

2. Formation volume factor for water

3. Supercompressibility factor of gas

Source: DOE, 1979 
test lasts for a period of two years. The detailed design of this test will be based on the results of the initial tests.

The decision of whether or not to proceed- to a two-year flow test w111 be based on several engineering and environmental factors. The engineering factors are related to the productivity of the well and are interrelated (i.e., it is usually poor ratings in several of these factors rather than in just one that would cause the test to be cancelled). The environmental factors are unexpected significant impacts which could arise that cannot be mitigated. The general engineering and environmental factors are presented below:

\section{Engineering Factors}

rate of flow of the well (pressure fluctuations)

reservoir parameters (e.g., drawdown)

temperature of the fluid total dissolved solids concentration (TDS)

gas/water ratio

\section{Environmental Factors*}

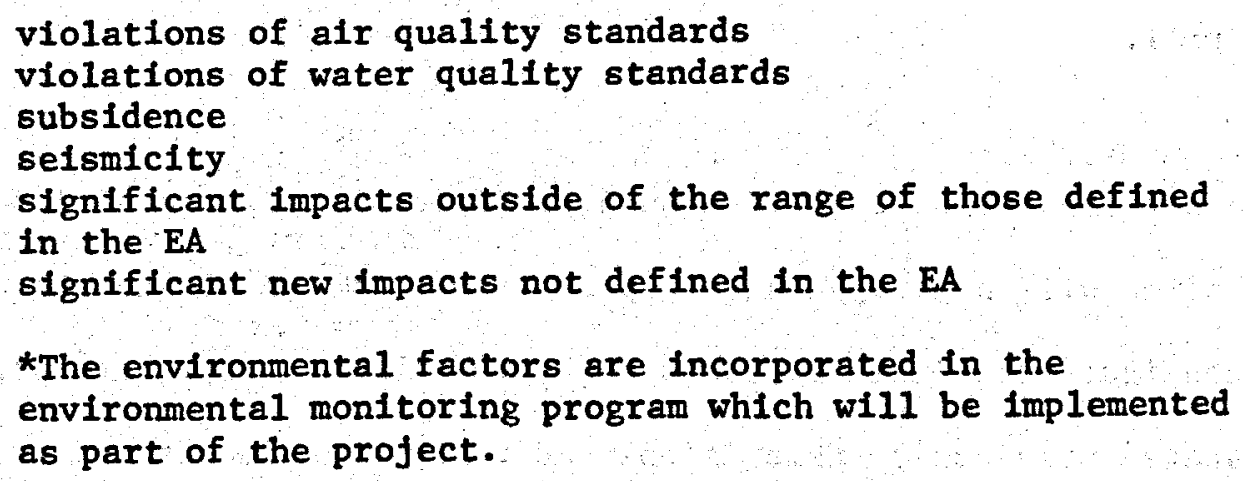

\subsubsection{Environmental Monitoring Program}

An environmental monitoring program (Appendix A) w111 be implemented

as part of the project. The purpose of the program is to monitor any 
environmental impacts that may result from the project and the levels of significance of these impacts. The information obtained by monitoring will be used to identify mitigation measures and corrective actions to be implemented to minimize the impact of the project. If any unexpected significant impacts arise which cannot be mitigated, DOE w1Il evaluate continuation of the project.

\subsubsection{Long-Term Activities}

If the decision is made not to continue activities at the site for two years, the well site will be abandoned. The wells will be plugged according to the regulations and permits of the Louisiana Office of Conservation. All production and disposal equipment and facilities w111 be removed. Wastes which cannot be reinfected will be trucked to a landfill operated in compliance with applicable local, State, and Federal regulations. After pits have been emptied, the liner will be removed. The board and plastic matting of the pad area will be removed. Materials which cannot be reused will be disposed of in an approved landfill.

If a developable resource is found, additional environmental documentation will be prepared to support the decision of whether or not to continue activities at the site beyond the two-year test period. As stated previously, this EA only addresses the impacts of drilling, developing, and testing the Gladys McCall well for a period of up to three years. 


\subsubsection{Accidents}

Although all reasonable precautions will be taken to prevent accidents, the possiblity of their occurrence and their consequent environmental impacts must be considered. Ensuring that project site personnel are alert at all times is the best means of preventing all accidents. Possible accidents are small incidental spills, large spills, fire, casing failure, and blowout.

Small incidental spills are likely to result from the transport of materials (e.g., gasoline, diesel fuel, drilling mud, and lubricants) or from minor leaks from equipment or vehicles. Such spills have few environmental consequences and can be mitigated easily. Small spills or leaks can be collected by a vacuum truck, although residual quantities of the spilled material may remain in the environment. Larger spills, which might result from surface equipment malfunction or failure, could be more damaging to the environment but, because of their size, can be identified readily by onsite personnel and mitigated quickly. Spills resulting from equipment malfunction or failure can be stopped by shutting off the appropriate equipment; the spilled material can then be collected by a vacuum truck and hauled to an approved landfill for disposal. Some residual materials may remain in the environment; however, all spills will be contained within the ring levee.

An accidental fire could result from careless handing of flammable materials or equipment malfunction. Fire extinguishers will be placed at several conspicuous locations on the project site and "no smoking" 
signs will be located no more than $30 \mathrm{~m}$ (100 ft) from the drilling rig and production facilities. The lack of buildings and dense vegetation around the project site greatly reduces the possibility of fire spreading beyond the site boundaries.

Although casing failure is unlikely to occur, it would be a more serious accident than a spill or fire because it would be more difficult to detect and mitigate. A casing failure could result from corrosion or from improperly setting the casing. The monitoring wells described in Appendix A will be sampled periodically and should help detect leakage through failed casing if failure occurs at shallow depths. Indicators at the wellhead may or may not identify this problem. Once casing failure is detected, drilling or production must stop, and costly workover procedures must be undertaken. If the workover is not successful, the borehole may have to be plugged and the well abandoned. Casing failures may also result in the most serious accident--8 blowout.

A blowout is the uncontrolled flow of subsurface fluids through the well into the environment. A variety of circumstances may cause well blowout; two of the most common causes in the Gulf coast are casing failures and gas kicks. Gas kicks occur during drilling when gas becomes trapped in the drilling fluids, expands, and, thus, reduces its weight. When the weight of the fluid is reduced to such an extent that it is unable to contain the pressure of the formation fluids, a blowout results. Although Blowout Prevention Equipment (BOPE) is 
installed to prevent such situations, it sometimes does not work or is not used early enough.

The risk of a blowout occurring in a geopressured zone is greater than that for a normal oil and gas well because of the greater depths and greater formation pressures involved. In the last two years there have been at least three major blowouts of commercial wells that were drilling in the geopressured zone in Louisiana. The first attempt by DOE to investigate geopressure resulted in a blowout. Estimates of the probability of a blowout based on incidence rates range between 2.4\% (Rehms and Goins, 1978) and 0.3\% (Dow Chemical Company, 1980) for all wells. Assuming that geopressured wells are twice as hazardous as the average (Rehms and Goins, 1978), the probability of a blowout for a geopressured well is estimated to be between $4.8 \%$ and $0.6 \%$. The higher estimate is an aggregation of minor blowout incidences in which minimal harm to equipment, personnel, or the environment resulted and of major blowout incidences in which significant harm resulted. The probability of minor blowouts in the geopressured zone is $4 \%$; for major blowouts it is roughly $0.8 \%$ (Rehms and Goins, 1978).

Several factors reduce the risk of a major blowout for the Gladys McCall project. The well is not a wildcat or stepout, both of which tend to have a greater incidence of blowouts, but a test well located in an area where the geology is well known. The reservoir's lateral dimensions and thickness are small and the formation would probably quickly bridge itself over, shutting off the uncontrolled flow. Finally, it is not anticipated that free gas will be encountered; therefore, 
gas kicks should not be a problem. However, the contractor will take all reasonable precautions and will comply with State of Louisiana regulations concerning blowout prevention and BOPE.

A recent study for DOE has identified several measures, in addition to those required for the project, that will minimize the risk of a blowout. These measures include compliance with U.S. Geological Survey rules, OCS Order No. 2, and GSS-OCST1, when applicable (Rehms and Goins 1978). These rules set highest standards for the operation, equipment, and training of personnel for geopressured drilling.

\subsection{Environmental Issues and Mitigation Measures}

\subsubsection{Environmental Issues}

The DOE plans and requires that the well test program have a minimal adverse impact on the physical, cultural, and economic environment of the study area. A summary of these adverse impacts is presented in the following sections.

1.4.1.1. Physical and Biological Issues - A Summary of Adverse Impacts

1) Contaminants, such as lubricants from vehicles and equipment and chemicals from spills and accidents, will be introduced into the environment if they occur outside the diked area. The degree of impact will depend on the location, 
type, amount, and duration of the spill or accident. Some species of flora will not be able to tolerate these occurrences and may be destroyed. Toxins may be picked up in the food chain and passed to herbivores and carnivores.

2) Wildlife may be displaced by the human activity, noise, or accidents. However, the disturbances of wildlife will be held to a minimum by the installation and maintenance of safety equipment and plans. (No adverse impact is expected on Rockefeller Wildlife Refuge.)

3) Blowouts or other accidents may introduce chemical and thermal pollutants into surface and groundwaters. However, blowout preventers, high pressure pipes and valves, and a spill prevention control and counter-measure plan will be installed and maintained to reduce the possibility of blowouts and accidents. Casings will be cemented as required by good operation procedures and Federal and state law.

4) Leakage from around casings may contaminate aquifers with chemical and thermal pollutants; but the DOE will use high pressure pipes and valves and will seal aquifers in manners accepted by the Federal and state governments to prevent their contamination.

5) Well testing may result in 1 and subsidence This, if it occurs, is expected to be a long-term impact.

6) Air quality will be adversely affected by the introduction of dust, vehicular emissions, and motor emissions associated with the well test program. Newer vehicles will be used which employ advanced pollution control devices for 
emissions. Thus, emissions will be short-term (i.e., the life of the project) and should not be significant.

7) There is the possibility of air pollution in the vicinity of the well test site should a blowout occur. The intensity of pollution depends on the nature and volume of the emitted fluids and gases. The DOE will attempt to minimize the possiblity of a blowout by installing and maintaining blowout preventers, high pressure pipes and valves and using weighted mud and high pressure mud pumps capable of injecting mud into the well to control pressures. The impacts of a blowout will probably be short-term but they may be significant.

8) Noise from machines and vehicles operating at the test site will raise the ambient noise level. This will be kept to a minimum by muffling as many machines and engines as feasible.

9) $\mathrm{H}_{2} \mathrm{~S}$ will be released during the initial testing phase of the project. However, it is impossible to assess the signifiance of this impact because the concentration of $\mathrm{H}_{2} \mathrm{~S}$ in the geopressured fluid is presently unknown.

\subsubsection{Cultural Issues - A Summary of Adverse Impacts}

1) Noise from the drilling and testing operation will affect the use of surrounding areas. Mufflers will be installed and maintained on all engines and vehicles to minimize impacts.

2) The aesthetic value of an area will be reduced by the presence of a drilling operation. The rig will be on site for 
about four months and the testing equipment should not be visible from any roadway except during times of flaring.

\subsubsection{3, Economic Issues - A Summary of Adverse Impacts}

Adverse economic impacts will occur if there should be an accident or a massive spill of some pollutants. Should either of these events occur, there may be a resulting land use change or contamination of a shallow water supply. However, the DOE is implementing precautions to prevent such accidents from occurring. Blowout preventers will be installed and high pressure pipes and valves will be used. Weighted mud and high pressure mud pumps capable of injecting mud into the well will be employed to control pressures. A drilling rig with spill prevention control and a counter-measure plan will be used at the test site. The reserve pond will be lined with impervious material to control infiltration and groundwater contamination or will have mud tanks. Portable sanitary facilities will be provided for construction crews and construction wastes will be transported to suitable disposal facilities.

\subsubsection{Summary of Mitigation Measures}

The Department of Energy is prepared to take all necessary measures to mitigate any adverse impacts on the physical, biological, and cultural resources of the study area. The following is sumary of these mitigation measures which will be implemented by the contractor. 
An existing board road will be used to avoid destruction of wetlands.

An existing well site will be used and an existing well will be used for brine disposal. All support facilities will be confined to the area within the existing levee system.

In preparing the site, the material from the low areas within the ring levee will be used to repair and upgrade the existing levee and well pad and no areas outside the levee will be disturbed.

A safety plan and accident prevention plan will be devised by the contractor and approved by the DOE. The plans shall specify safety equipment and practices to be implemented and procedures to be followed if an accident should occur.

Blowout preventers, high pressure pipes and valves, weighted muds, and high pressure pumps will be installed and maintained to reduce the possibility of blowouts and accidents.

Casings will be cemented as required by good drilling practices and Federal and state laws.

Well installation and completion will meet or exceed all Federal and state guidelines for such an operation.

Newer vehicles will be used which employ advanced pollution control devices for emissions. 
As many machines and engines as possible will be muffled to minimize noise impacts.

Contaminated fluids contained in the diked area will be collected into an impermeably lined storage pit. All fluids which cannot be reinjected will be disposed of in an approved landfill upon completion of the project.

Portable sanitary facilities will be provided for construction crews and construction wastes will be transported to suitable disposal facilities.

Upon completion of the proposed action, the contractor will remove all foreign substances and materials from the project area and restore the site as closely as possible to its pre-project condition.

The contractor shall develop a spill control and countermeasure plan.

The well site and access road will not adversely affect the function of the floodplain of the area because the facility is using the existing road and we11 site.

Finally, an environmental monitoring program will be conducted for the drilling and testing operations. The Louisiana Geological Survey and the DOE will evaluate the results of the monitoring program. Should unacceptable adverse impacts result from the proposed action, the DOE will stop the test until the problem(s) is resolved. 


\section{REFERENCES}

Bernard, W.J.

1977 Preliminamy results of research: Site specific investigations of the geopressure energy resource of southern Louisiana. Petroleum Engineering Department, Louisiana State University, Baton Rouge, Louisiana.

Department of Energy

1979 A geopressured-geothermal resource test well. A proposal by the Grumy Companies to manage and supervise the drilling, testing, and evaluation on the Grumy Federal, Inc. -- DOE No. 2 Gladys McCall, Comeron Parish, Louisiana. 3 vols. Submitted to R.T. Stearns, DOE/Nevada Operations Office, Las Vegas, Nevada. April 20. Unpublished data.

DOW Chemical Company, U.S.A.

1980 Letter to Robert Oliver, Department of Energy, January.

Hawkins, M.F., Jr.

1977 Investigations on the geopressure energy resource of southern Louisiana: Final Report. ERDA Contract EY-76-S-05-4889. Petroleum Engineering Department, Louisiana State University, Baton Rouge, Louisiana.

Newchurch, E.J., A.L. Bachmann, C.F. Bryan, D.P. Harrison, R.A. Muller, J.P. Newman, Jr., C.F. Smith, Jr., J.I. Bailey, G.G. Kelly, K.C. Reibert

1978 Assessment of selected geopressured-geothermal prospect areas: La. Gulf Coast, Region. Vol II. Environmental Baseline Data. Institute for Environmental Studies, Louisiana State University, Baton Rouge, Louisiana.

Rehms, W.A., and W.C. Goins, Jr.

1978 Geopressure blowout control. Department of Energy. pp. 85, 90-91. 


\subsection{Introduction}

All development of surface facilities and injection wells will take place within the existing levee system. Land to be used is in private ownership; mineral rights are being acquired at this time by the contractor. The well site is located in Section 27, T15S, R5W in Cameron Parish, Louisiana. The nearest residential and commercial developments are $3.7 \mathrm{~km}(2.3 \mathrm{mi})$ to the north on the Grand Cheniere Ridge. Overall character of the study area is rural wetland used for pasture and as wildlife habitat. The marshes are brackish and are of low elevation and low relief. The following sections describe the existing environment of the study area around the proposed well site in sufficient detail to permit a discussion of impacts of the proposed action on the environmental system.

\subsubsection{Physiography}

The study area is within the Chenier Plain of southwest Louisiana, a physiographic region characterized by relict beach ridges crossing a low marsh coastal plain. The region lies unconformably on the Pleistocene Prairie terrace, an oxidized and deeply dissected surface (Fisk, 1948). The Chenier Plain of Recent deposits extends from the Pleistocene outcrops on the north to the Gulf of Mexico on the south, and from the Mississippi River deltaic plain on the east into Texas on the west. One of these relict beach ridges, Grand Cheniere, forms the northern quarter of the study area. Grand Cheniere, the Gulf shoreline 
between 1100-1250 years ago, is more than $34 \mathrm{~km} \mathrm{(2l} \mathrm{mi)} \mathrm{long} \mathrm{and} \mathrm{has} \mathrm{a}$ maximum elevation of $3.7 \mathrm{~m}$ (12 ft) (Gould and Morgan, 1962). Widths average $183 \mathrm{~m}(600 \mathrm{ft})$ and range from 31 to $458 \mathrm{~m}$ (100 ft to $1500 \mathrm{ft}$ ). In cross-section the chenier is asymmetrical, steep on the Gulf or south side and gently sloping inland toward the north (Byrne et al., 1959). Sand and shell compose the lenticular beach ridges which average $2.1 \mathrm{~m}$ (7 ft) in thickness, but may range from .6 to $4.6 \mathrm{~m}$ (2 $\mathrm{ft}$ to $15 \mathrm{ft}$ ) in thickness. Cheniers overlay old Gulf bottoms of sands and silty clays. Depths to the Pleistocene are on the order of $6.1 \mathrm{~m}(20 \mathrm{ft})$. Between the cheniers are natural or man-made water bodies and marshes. The marsh of organic clays and silts overlay mudflats and old Gulf bottoms. The marshes, less than $1 \mathrm{~m}$ ( $3 \mathrm{ft}$ ) above sea level, are poorly drained by tidal channels and larger regional rivers. Cheniers and beach ridges control the natural flow through the area. Numerous small lakes are scattered throughout the Chenier Plain. Man has modified flow by canals, levees, weirs, and petroleumrelated access routes. An existing levee surrounds the proposed well site and is continuous except for several sma11 breaches. This levee, which surrounds much more than the well site, was related to some form of marsh drainage and land reclamation scheme which apparently failed. This levee is not related to the proposed action.

\subsubsection{Geology}

The well site is in the north central section of the Gulf coast of the United States. The regional geology is dominated by the Gulf coast geosyncline whose axis is just seaward of the shoreline (Figure 2-1). Regional strike of the geologic beds is east-west and they dip as a monocline toward the axis of the geosyncline (Bernard and Leblanc, 1965). The geosyncline 


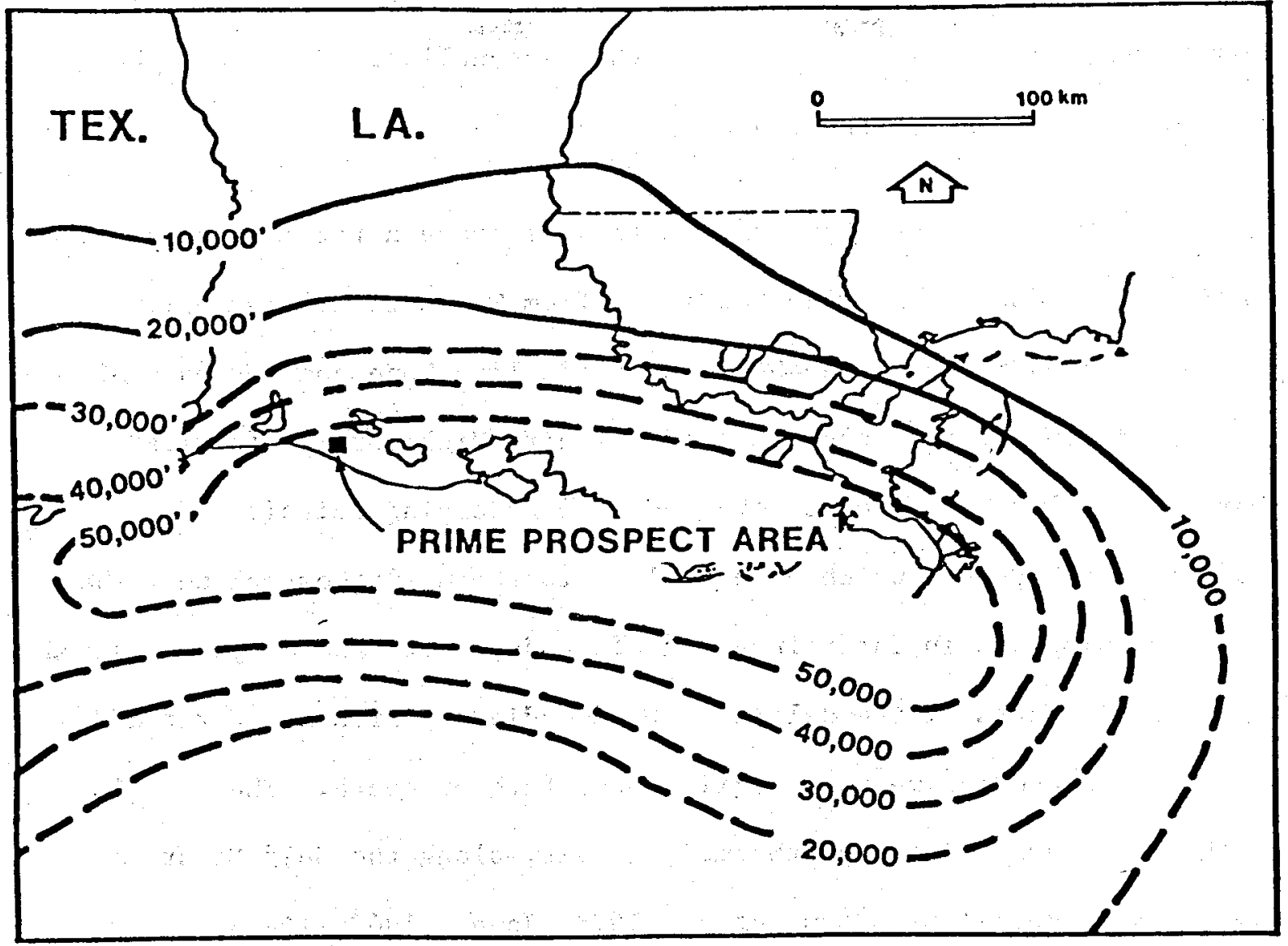

Figure 2-1. Gulf coast geosyncline: approximate thickness of the Cenozoic of Loulsiana (Modified from Hardin, 1962). 
is a huge prism of clastic sediments derived from the north and northwest. The beds dip and thicken into the geosyncline. Table 2-1 shows the geologic column for the region.

The Frio formation is the geologic entity of concern for this project. The Frio extends across south Louisiana from Texas to Mississippi. The upper boundary is the Anahuacian Marginulina Zone and the base of the Frio is the "first occurrence of definite Vicksburgian fossils" (Warren, 1957). The Frio is composed of overlapping deltaic and inter-deltaic systems which have built into the Gulf geosyncline. The formation displays an interfingering of sands, silts and clays deposited in the updip parts of the deltas. The downdip deposits are neritic environments and become more argillaceous farther south. The relation of the Frio Formation to geothermal activity along the Gulf Coast is described in detail by Bebout et al, 1976; Jones, 1968, 1969a, 1969b, 1970a, 1975; Jones and Wallace, 1973; and Wallace, 1969.

The proposed well site is within the Rockefeller Refuge Prime Prospect Area. Four geopressured aquifers underlie the proposed well site and exist between $4,441 \mathrm{~m}(14,560 \mathrm{ft})$ and $5,033 \mathrm{~m}(16,500 \mathrm{ft})$. Figures 2-2 and 2-3 show the top of the first geopressured horizon (DOE, 1979) of interest to this proposed action. Table 2-2 shows the estimated top of the four geopressured sands and the estimated net porosity.

The geology under the well site may be characterized as follows(DOE, 1979):

1) a drainage area of approximately $41.4 \mathrm{sq} \mathrm{km}$ (16 sq mi), uncomplicated by major faulting; 
Table 2-1. Geologic Column for the Study Area.

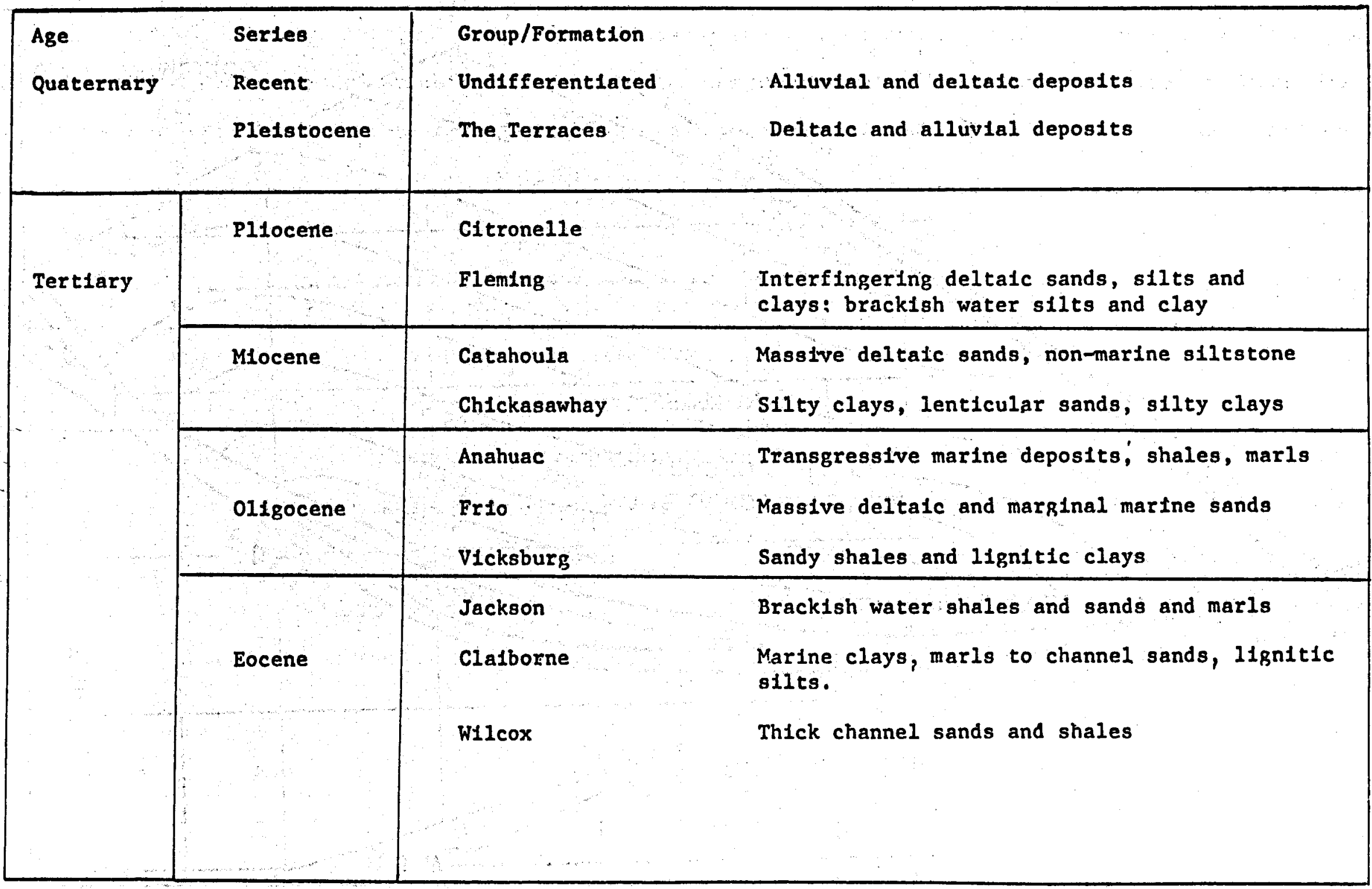




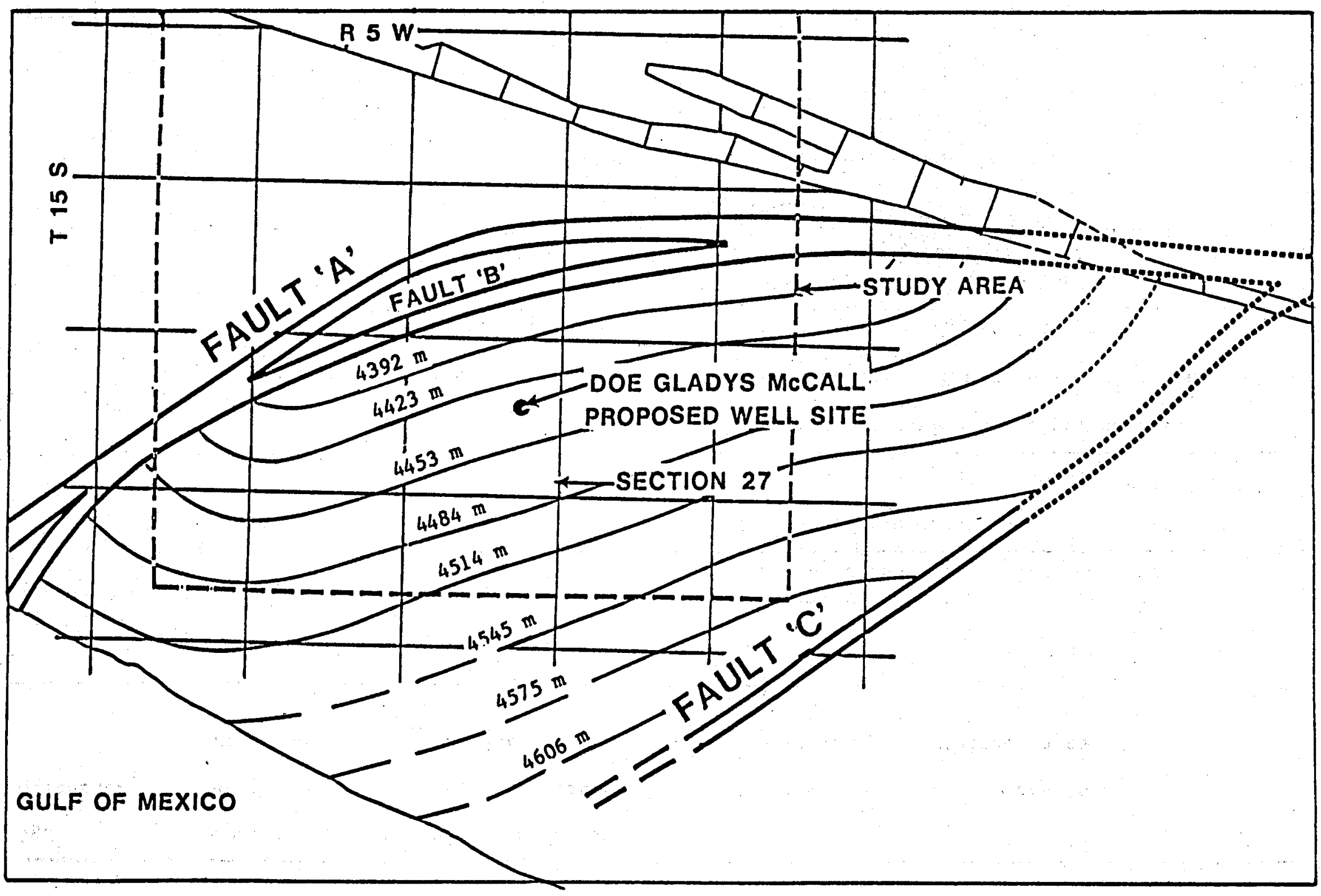

Figure 2-2. Top of the geopressured zone beneath the region (DOE, 1979).

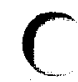



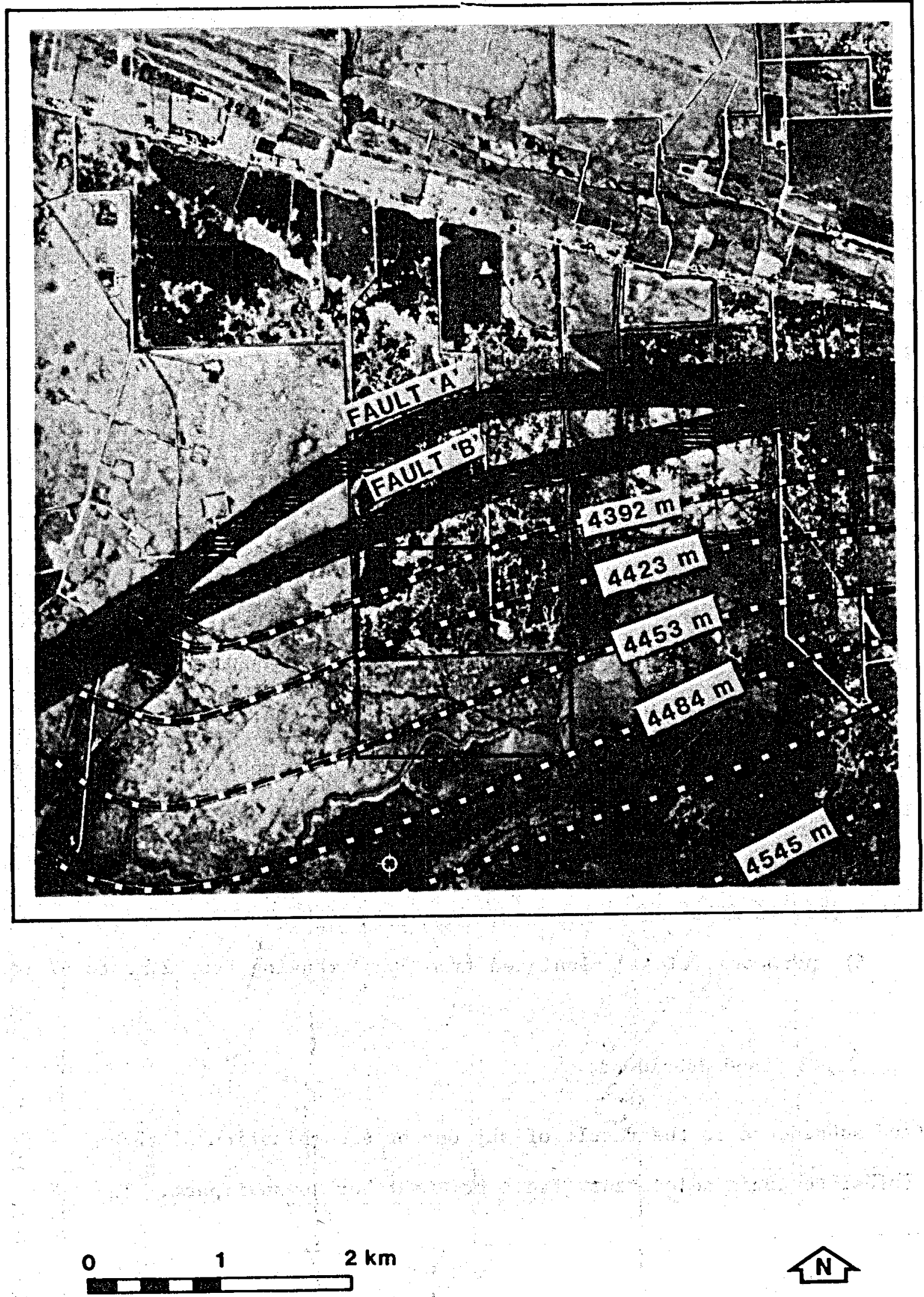

Figure 3-3. Top of the geopressured zone beneath the study area (DOE, 1979). 
Table 2-2. Estimated Net Porosity and Depth to Top of Geopressured Sands to be Penetrated and Tested by the Proposed Action.

\begin{tabular}{|c|}
\hline $\begin{array}{l}\text { Geopressured } \\
\text { Sand }\end{array}$ \\
\hline
\end{tabular}

No. 1

$4441(14,560)$

18

No. 2

$4602(15,090)$

18

No. 3

$4728(15,501)$

17

No. 4

$4926(16,150)$

17

Source: DOE, 1979

2) 10.4 to $13.3 \mathrm{cu} \mathrm{km}(2.5$ to $3.2 \mathrm{cu} \mathrm{mi})$ of sand volume;

3) $227 \mathrm{~m}$ (745 ft) net geopressured sand penetrated;

4) maximum recorded mud temperatures of $147^{\circ} \mathrm{C}\left(294^{\circ} \mathrm{F}\right)$ at

$5185 \mathrm{~m}(17,000 \mathrm{ft})$ which converts to a bottomhole temperature of $162{ }^{\circ} \mathrm{C}$ $\left(324^{\circ}{ }^{\circ}\right)$;

5) bottomhole pressures of 1021 atmospheres $(15,000 \mathrm{ps} 1)$ at 5124 m $(16,800 \mathrm{ft})$;

6) permeabilities (calculated from logs) ranging from 2 ind to $47 \mathrm{md}$.

\subsubsection{Land Subsidence}

Land subsidence is the result of any one or a combination of three causes: tectonic adjustment, fault movement or human impact. The 
study area is undergoing land subsidence at present due to the two natural causes. First, the entire coast of southwestern Louisiana is undergoing regional tectonic subsidence, due to general compaction of sediments, at a rate of approximately $5 \mathrm{~mm}(.2 \mathrm{in})$ per year (Holdahl and Morrison, 1974). Secondly, subsidence is probably occurring due to fault movement resulting from differential compaction and slippage. Man-caused subsidence, due to the removal of ofl and gas or ground water, has not been reported or observed, but minor subsidence may be occurring above active oil and gas fields in the area.

Local areas of differential subsidence in excess of regional tectonic adjustment, such as active oll fields, may be detectable if an adequate network of bench marks exists, and if the network has been surveyed over a sufficient time span to allow movement of bench marks to be detected. In the Rockefeller Refuge Prime Prospect area the only useful bench marks surveyed by the National Geodetic Survey are located along a single line following Grand Cheniere Ridge, which, at its closest point, is $3.2 \mathrm{~km}(2 \mathrm{ml})$ north of the proposed well site. of the seven bench marks surveyed both in 1948 and 1965 , the greatest differential movement has been about $.3 \mathrm{~m}(.9888 \mathrm{ft})$, and occurred only at one bench mark. The existing bench mark network is not adequate by itself for mapping differential subsidence in the study area because

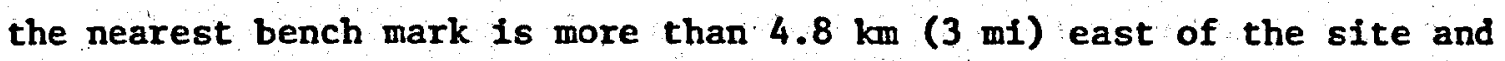
survey lines do not extend south from the chenier.

\subsubsection{Tectonic Activity}

The Rockefeller Refuge Prime Prospect Area in which the study area is located is defined by a series of arcuate, east-west trending faults 
(Newchurch et al,,1978). Faults occur in the vicinity of the study area and delineate the reservoir for the proposed well test (DOE, 1979). Fault displacement indicates that the area has been active in the past, but there is no known literature which indicates that it is active at present. There are no surface expressions to indicate fault movement in the study area.

Seismic hazard in the study area is very low to non-existent (Algermissen, 1969; Algermissen and Perkins, 1976). Potential for seismic risk is described on a scale of 0 to 3 where Zone 0 means no damage, Zone 1 means minor damage, Zone 2 means moderate damage, and Zone 3 means major damage. Such a scale is based on historical data which considers only the intensity of the earthquake, not the frequency. The study area has a seismic potential of zero (Algermissen and Perkins, 1976) even though there have been two recent earthquakes in Louisiana. On October 19, 1930, an intensity VI (Modified MERCALLI [MM] Scale) earthquake was centered south of Donaldsonville at approximately $30^{\circ} \mathrm{N}$ latitude and $91^{\circ}$ W longitude or $193 \mathrm{~km}$ (120 mi) east of the proposed well site. Some brick chimneys were cracked or the tops knocked down in Gonzales, Louisiana, $24 \mathrm{~km}$ (15 mi) north of the epicenter. A second earthquake occurred on November 19, 1958, in Baton Rouge, Louisiana, $183 \mathrm{~km}$ (114 mi) east of the study area. An intensity of $V$ (MM scale) is estimated for this earthquake which shook houses and rattled windows. A major east-west fault, which runs through Baton Rouge, is active and has moved as much as $6 \mathrm{~cm}(.20 \mathrm{ft}$ ) per year from 1959 to 1969 (Wintz et al., 1970). 


\subsubsection{Soils}

Two soil associations are found in the study area. The Harris, Cheniere Varient-Palm Beach Association are the clayey and sandy soils of the Grand Cheniere Ridge. The Harris-Salt hater Marsh Association are the mineral and organic soils of the wetlands. On the chenier, the Harris, Cheniere Variant-Palm Beach Association has a severe limitation because of flooding resulting from hurricane storm-surge. Water impoundments are generally not attempted because of the high seepage rates. The dominant use of this area is pasture. In the wetlands, the HarrisSalt Water Marsh Association has a very severe flooding problem as the area is inundated most of the time. Ponds may be maintained through the use of the fair levee building material available in the Harris Moderately Saline Phase. The dominant use of this area is for wildlife habitat and drained areas for pasture. The soils are neutral (Ezernack, 1979).

\subsubsection{Prime and Unique Farmland}

There are no prime or unique farmlands in the study area (SCS, 1978)

\subsection{Hydrology and Water Use}

\subsubsection{Groundwater}

\subsubsection{Occurrence}

Fresh groundwater is available from two sources in the study area and the surrounding area: 1) the Chicot aquifer, which extends to 
a depth of about $396 \mathrm{~m}(1,300 \mathrm{ft})$, and 2) the near-surface sands of the cheniers. The Chicot aquifer, a massive system of Pleistocene sands and gravels, is the principal source of groundwater for several parishes of southwest Louisiana (Jones, Turcan and Skibitzke, 1954). The aquifer is a continuous hydraulic unit from the Mississippi River valley westward into Texas, and from surface recharge areas approximately $80 \mathrm{~km}(50 \mathrm{mi})$ north of the study area to an undetermined distance off shore. About $24 \mathrm{~km}$ (15 mi) inland from the coast, the Chicot aquifer is confined beneath fine-grained, low permeability sediments of Recent age, coastal marsh deposits, which are 10 to $20 \mathrm{~m}$ (30 to $60 \mathrm{ft}$ ) thick. The second, and much more limited potential groundwater source, is the chenlers, which occur within the marsh deposits overlying the Chicot aquifer. Cheniers are ancient, topographically high beach ridges which extend from the surface to depths of about $4.6 \mathrm{~m}$ (15 ft) into the surrounding coastal marsh silts and clays. These narrow strips of high land are permeable areas which receive fresh water recharge from precipitation and salt water recharge from occasional storm tides.

\subsubsection{Quality}

Groundwater quality information is available in the region from two sources: 1) chemical analyses of water samples from wells and 2) estimates of groundwater salinity from electrical logs of wells. Chemical analyses are available for only two wells completed in the Chicot aquifer locally, and both are located on Grand Cheniere Ridge approximately $6.4 \mathrm{~km}$ ( $4 \mathrm{mi})$ northeast of the well site. These analyses are listed in 
Table 2-3 and show that the water from these wells is above the recomnended limit of $250 \mathrm{ppm}$ chlorides set by the Environmental Protection Agency (EPA, 1976).

The depth to the base of various categories of groundwater, based on salinity determined mostly from evaluations of electrical logs, is shown in Figure 2-4. In the study area, fresh water (1ess than $250 \mathrm{mg} / 1$ chlorides, or less than about $700 \mathrm{mg} / 1$ dissolved solids) extends to between 60 to $90 \mathrm{~m}$ (200 to $300 \mathrm{ft}$ ) below the surface, and therefore into the upper sands of the Chicot aquifer. South and west of the study area, the base of fresh water increases to more than $183 \mathrm{~m}$ (600 ft) below the surface. Slightly saline water $(1,000$ to 3,000 mg/l dissolved solids) occurs between approximately 90 to $183 \mathrm{~m}$ (300 to $600 \mathrm{ft}$ ) in the area, and moderately saline water (greater than $3,000 \mathrm{mg} / 1$ dissolved solids) occurs between approximately 183 to $213 \mathrm{~m}$ (600 to $700 \mathrm{ft}$ ). Sands below this depth contain water in excess of $3,000 \mathrm{mg} / 1$ dissolved solids.

The cheniers are potential sources of limited amounts of fresh groundwater. However, storm tides occasionally flood the cheniers, resultIng in recharge of saline water to these shallow water-table aquifers. No analyses are available for groundwater in the cheniers.

\subsubsection{Quantity}

The quantity of water available from the Chicot aquifer is vast because the aquifer system is several hundred meters thick, has a high 
Table 2-3. Chemical analyses from water wells completed in the Chicot Aquifer, approximately $6.4 \mathrm{~km}(4 \mathrm{mi})$ northeast of the proposed well site.

\begin{tabular}{lcc} 
Well No. & Cn 41 & Cn 42 \\
\hline Date & $2-2-55$ & $2-2-55$ \\
\hline $\begin{array}{l}\text { Screen Depth } \\
\text { (feet) }\end{array}$ & $\begin{array}{c}140 \mathrm{~m} \\
(460)\end{array}$ & $\begin{array}{c}140 \mathrm{~m} \\
(460)\end{array}$ \\
\hline $\begin{array}{l}\text { Concentrations (mg/1) } \\
\text { Total Iron }\end{array}$ & 1.2 & 1.2 \\
Calcium & 48 & 44 \\
Magnesium & 19 & 17 \\
Sodium & 408 & 317 \\
Potassium & -- & -18 \\
Bicarbonate & 416 & 360 \\
Sulfate & 2.1 & 0.5 \\
Chloride & 547 & 416 \\
Dissolved Solids & 1230 & 1000 \\
Hardness as CaCo 3 & 198 & 181 \\
\hline
\end{tabular}

Source: USGS files, Baton Rouge, Louisiana 


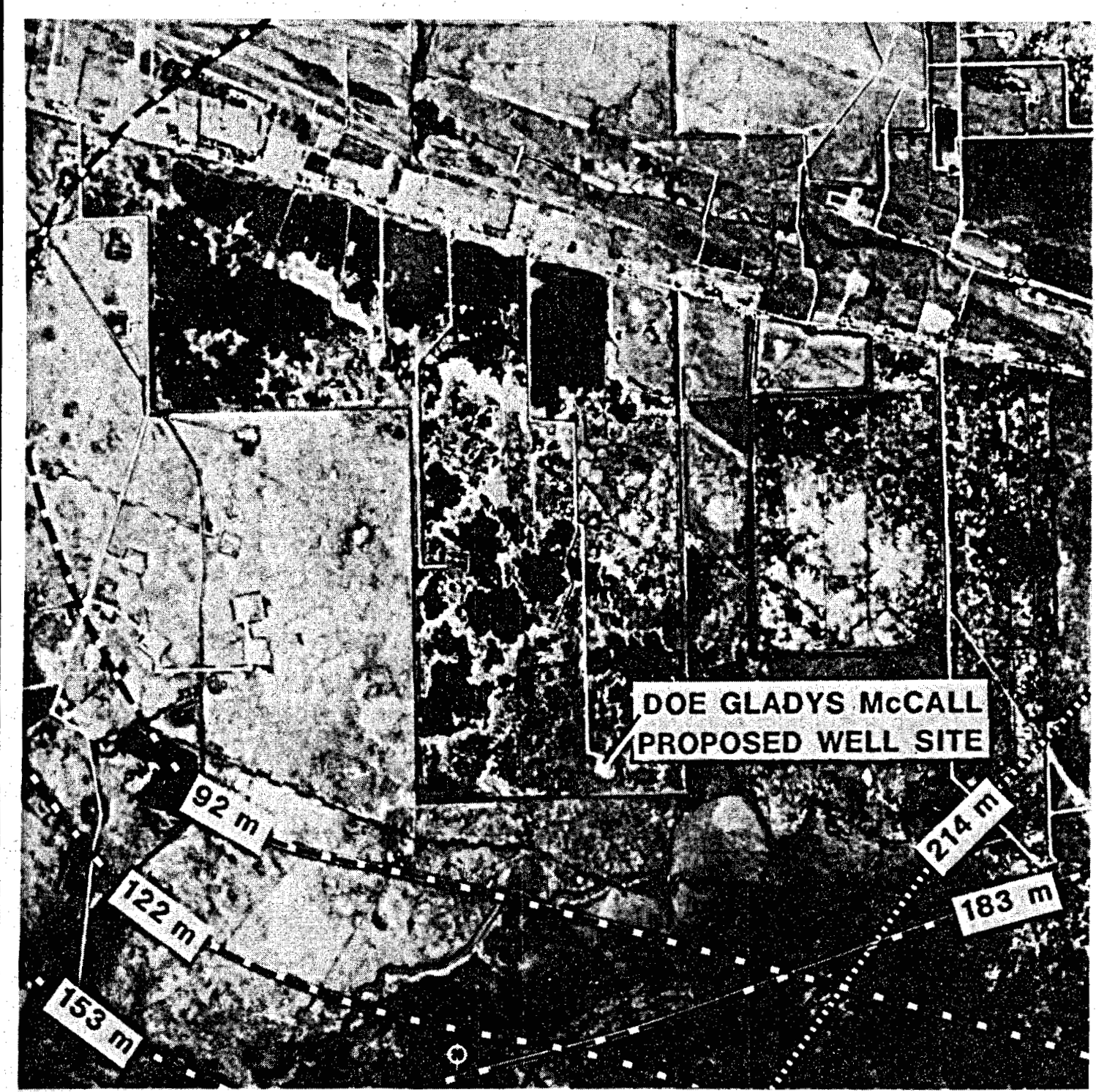

- - ELEVATION OF BASE OF FRESH GROUND WATER

$-\infty$ ELEVATION OF BASE OF SLIGHTLY SALINE GROUND WATER

ELEVATION OF BASE OF MODERATELY SALINE GROUND WATER
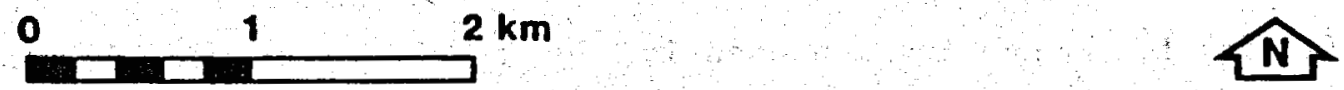

Figure 3-4. Groundwater quality/depth relationship in the Chicot aquifer (Rollo, 1960; Winslow et al 1968). 
average permeability of about $5,678 \mathrm{l} / \mathrm{da}(1,500 \mathrm{gal} / \mathrm{da}$ per sq ft) (Harder et al., 1967) and extends over thousands of square kilometers of Louisiana and Texas. In the study area the quantity of water available is limited only by the quality of the water required, 1.e., fresh water is limited to the upper few hundred meters of sediments. Local groundwater production appears to be limited to residential wells which produce less than about 1,900 1/da (500 gal/day).

\subsubsection{Use}

Groundwater use in the region is limited to domestic supply wells used by residents along Grand Cheniere Ridge, $3.7 \mathrm{~km}(2.3 \mathrm{mi})$ north of the Gladys McCall well. Generally, each residence has a well completed in the Chicot aquifer between 60 and $150 \mathrm{~m}$ (200 and $500 \mathrm{ft}$ ) deep. Additional shallow, domestic supply wells exist which are completed in the shallow chenier sands as deep as about $6 \mathrm{~m}(20 \mathrm{ft})$. Locally, groundwater is not developed for industrial, municipal or agricultural use.

In addition to local residential use, development of the Chicot aquifer system for rice irrigation in large areas of southwestern Louisiana, and for industrial uses in Lake Charles $64 \mathrm{~km}$ (40 mi) to the northwest, has resulted in the decline of water levels throughout southwestern Louisiana. In the region, water levels in the Chicot aquifer have declined from a few meters above sea level in the early 1900 s to about 3 m (10 ft) below sea level presently, due to the effects of developments of groundwater supplies inland (Zack, 1971; USGS, 1978). 
Between $610-915 \mathrm{~m}(2,000-3,000 \mathrm{ft})$ below the surface the geologic section is dominated by saline water-bearing sands. Some of these saline aquifers are used as disposal zones for brine in nearby gas fields. Permits for salt water disposal wells filed with the Louisiana office of Conservation indicate that the closest disposal wells are in Little Pecan Lake field, 8 to $9.6 \mathrm{~km}$ (5 to 6 mi) east of the study area, and are completed between 610 and $915 \mathrm{~m}$ $(2,000$ and $3,000 \mathrm{ft})$ below the surface. The four disposal wells in the field inject between 3,200 to $556,4001 /$ da (20 to 3,500 barrels/ day.

\subsubsection{Surface Water}

The occurrence and movement of surface water in the area of the proposed well are typical of the coastal Louisiana marsh setting. Surface water parameters are closely related to both physical and cultural landscape features. In the coastal setting, climatic and geomorphic factors determine the range and character of surface water activity, establishing predictable hydrologic responses in a natural setting. However, in addition to a complex set of physical variables, there exists in the coastal region an equally complex set of cultural features.

Canals, levees, access roads, spoil deposits, weirs and other manmade structures interact with natural drainage patterns in the wetlands area to produce a distinctive combination of hydrologic processes and responses. This section describes the resulting surface water 
characteristics of stream regime, water quality and water resources development as they pertain to the proposed action in the study area.

\subsubsection{General Basin Hydrology}

The study area is located in the Mermentau-Vermilion-Teche River Basin, comprising an area of about $17,431 \mathrm{~km}^{2}\left(6730 \mathrm{mi}^{2}\right.$ ) (Louisiana Stream Control Commission, 1978). Basin drainage is primarily north to south in response to a regional elevation gradient ranging from over $91 \mathrm{~m}(300 \mathrm{ft})$ above sea level in the upper basin, to sea level in the marshes of the lower basin near the well site. Flatness of terrain and the ubiquitous canals of the lower part of the basin in the vicinity of the proposed well site allow much cross-basin transfer of surface water, thus creating a fairly indeterminate drainage pattern for much of the marsh area around the well site.

Most of the maxsh surface around the well site is at or near mean sea level; therefore surface drainage is sluggish, both as confined (channel) and unconfined (sheet) flow. The only natural break in topography is Grand Cheniere Ridge, with a maximum elevation of less than $2 \mathrm{~m}(7 \mathrm{ft})$. Because of its location north of the well site, the ridge significantly interrupts gradient flow through the study area. Additional flow impediments are levees, access roads and spoil banks along the sides of canals in and around the study area.

Details of surface drainage patterns around the study area are shown in Figure 2-5. Drainage divides, such as Highway 82 and the Grand Cheniere Ridge to the north, as well as existing access roads into and near the well site, tend to confine and direct surface drainage 


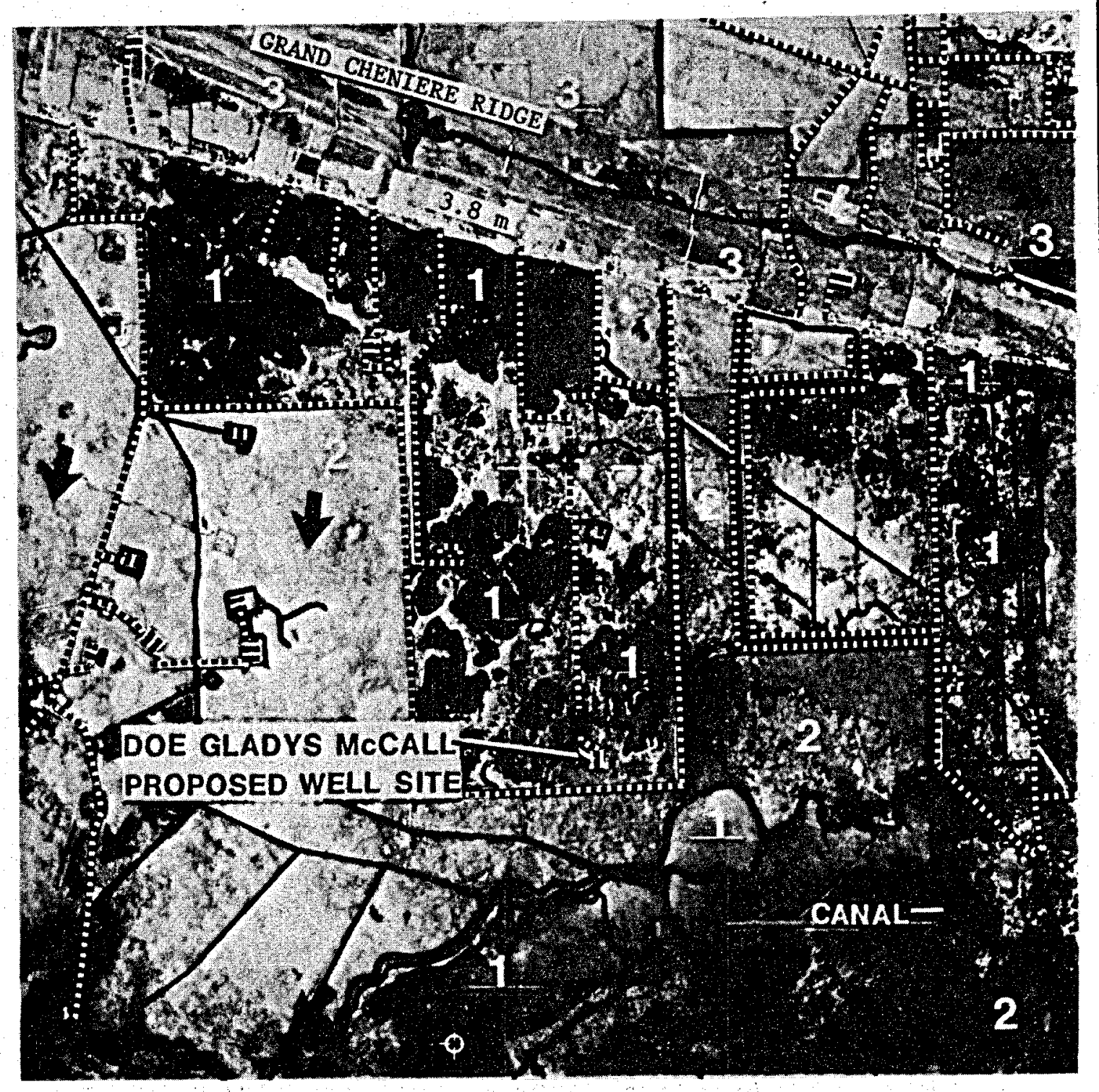

............ LEVEE, ROAD, BUILT-UP AREA, IMPOUNDMENT

1 CANAL, STREAM, OPEN WATER

2 MARSH

3 RIDGE, WELL-DRAINED

I WOODEN BRIDGE

$\Rightarrow$ DIRECTION OF NORMAL FLOW

$3.8 \mathrm{~m} 100$ YR MAX FLOOD ELEVATIONS (meters above MSL)
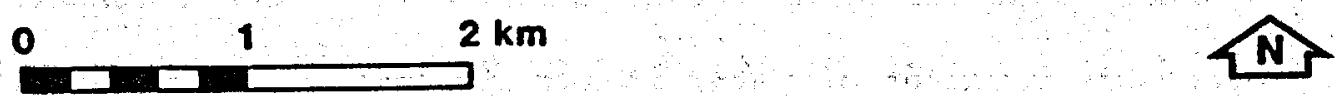

Figure 3-5. Surface water features and generalized water movement in the study area. Flood elevations from Newchurch et $a 1 ., 1978$. 
to some extent; but all restricting features are breached by streams, canals or culverts. Notwithstanding these alterations, the general direction of the gradient flow pattern is indicated by arrows in Figure 2-5.

Surface water flows south to southwest through the study area, following the small natural gradient in elevation toward Hog Bayou (Figure 2-5). Inside the impoundment around the well site, water flows in this same direction under the plank access road in two places - about $91 \mathrm{~m}$ (300 ft) north of the well.site and about $1.6 \mathrm{~km}(1 \mathrm{mi})$ north of the well site where two wooden bridges are located in the road. The levees impounding the well site are presently in generally good condition with two exceptions: a possible weak spot about $0.8 \mathrm{~km}(0.5 \mathrm{mi})$ south of Highway 82 on the east levee; and an old water control structure near the southeast corner of the impoundment (Baccigalopi, 1979). Some leakage might occur in these two places, but otherwise the levees provide good containment of surface water within the area of the we11.

Surface drainage in the marshes around the well site is regulated by the combined effects of runoff from the upper parts of the basin, tidal oscillations and weather events. Southerly winds drive Gulf waters up against the coastline, causing northerly movement of water and flooding of the marshes. Northerly winds have the opposite effect, at times almost emptying the marshes. Under certain conditions there is no detectable movement of water in any direction. Drainage patterns, water levels and salinities in the marshes and hydrologically connected streams and canals are thus caused to fluctuate on a daily, or even hourly, basis. 
Excessive local rainfall, river flooding and tropical cyclones with their attendant storm surges inundate the portion of Louisiana's lowlying coastal region in which the proposed well site is located. Although relatively rare, the tropical cyclone is a dangerous part of the natural environment of the study area, particularly in its effects upon local hydrologic regimes. Precipitation in excess of $760-890 \mathrm{~mm}$ (30-35 in) is not unusual during the course of these storms, and the probability of hurricane-force storms in the study area during any year is about $7-8 \%$ (USCE, 1976).

\subsubsection{Water Quality Characteristics}

The area around the proposed well site is presently designated as "effluent limited" (meeting established water quality criteria or reasonably expected to meet the standards after application of technology to control industrial and municipal discharges) (Domingue, Szabo and Associates, Inc., 1975).

Salinity conditions in the study area affect vegetation, wildife and so11 resources. Figure 2-6 shows the average distribution of surface salinities in the Louisiana coastal zone. On the average, surface salinities around the well site range between 5.0 and 15.0 ppt (parts per thousand) in the open marshes; with lakes and canals being mostly fresh. Water exchange by tidal action is somewhat restricted by cultural controls and by the relatively few openings between the Gulf and the marsh (Barrett, 1971). 


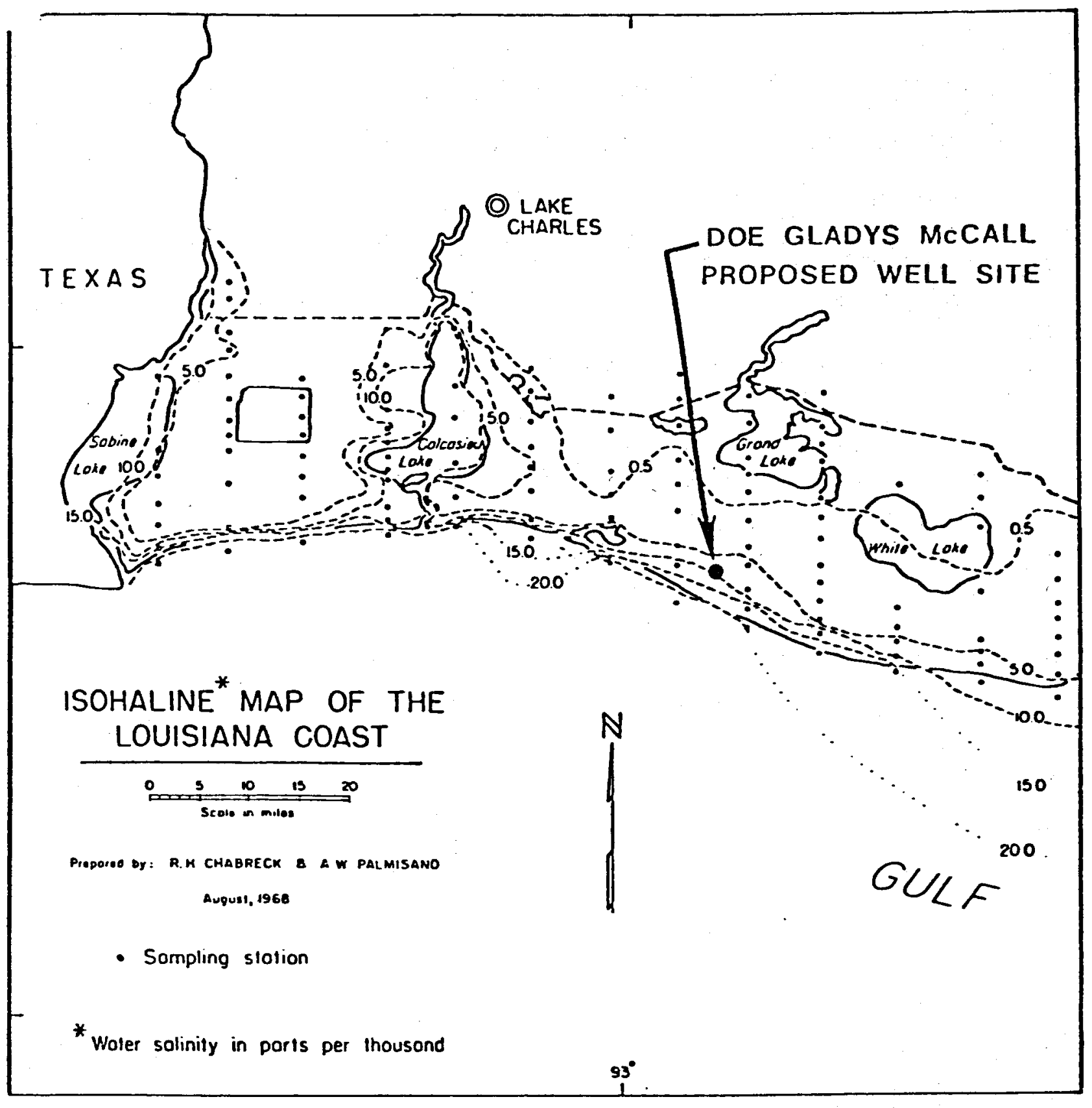

Figure 2-6. Isohaline map of the Louisiana coast (Modified from Chabreck and Palmisano, 1968). 
A preliminary assessment of water quality conditions has been conducted for the area of the well site pursuant to the Louisiana 208 water quality program, funded under the Federal Water Pollution Control Act of 1972 (Newchurch et al, 1978). Owing to tidal influences, low river flows and unsewered communities, severe oxygen depletion and high fecal coliform counts plague much of the coastal waters.

Table 2-4 summarizes available information on water quality in the wetlands around the proposed well site. Table 2-5 summarizes water quality criteria and water use designations in the vicinity of the well site.

Table 2-4. Initial Water Quality Assessment, Segments 05-E, 05-F, and 05-G.

Statewide Priority

Problem Ranking

Municipal and Industrial

Discharges

Specific and Localized

Problems

Sediment and Nutrients

Low Concentrations of Pollutants (herbicides, pesticides)
1

Pecan Island unsewered Assessment

No significant pollution

3

Agricultural production: rice, sugar cane

4

No significant problem until sufficient monitoring data prove otherwise

Source: Newchurch, et al, 1978

\subsubsection{Water Resource Development}

No municipal or domestic water supply is taken from surface water sources in the study area, but most stream segments are classified as suitable for "primary and secondary contact recreation" and for "propagagion of fish and 
Table 2-5. Water Quality Standards*k* (Belected parameters) and Water Use Designationg** (selected stream segments).

\begin{tabular}{|c|c|c|c|c|c|c|c|c|c|c|}
\hline Segment & $\begin{array}{l}\text { Wa } \\
\text { A }\end{array}$ & $\begin{array}{c}\text { ter } \\
B\end{array}$ & $\begin{array}{l}\text { Uses } \\
\text { C D }\end{array}$ & $\begin{array}{c}\mathrm{Cl} \\
(\mathrm{mg} / \mathrm{I})\end{array}$ & $\mathrm{so}_{(\mathrm{mg}}^{\left.\mathrm{SO}_{1}\right)}$ & $\begin{array}{c}\mathrm{DO} \\
\text { (mg/1) }\end{array}$ & $\underset{\text { (range) }}{\mathrm{pH}}$ & $\begin{array}{c}\text { TDS } \\
(\mathrm{mg} / 1)\end{array}$ & $\begin{array}{l}\text { Temp. } \\
\left({ }^{\circ} \mathrm{C}\right)\end{array}$ & $\begin{array}{l}\text { BAC* } \\
\text { STD }\end{array}$ \\
\hline $\begin{array}{l}\text { LACASSINE BAYOU } \\
\text { (headwaters to } \\
\text { Mermentau R.) }\end{array}$ & A & B & C & 90 & 30 & 5.0 & $6.0-8.5$ & 260 & 32 & 1 \\
\hline $\begin{array}{l}\text { MERMENTAU RIVER } \\
\text { (Grand Lake to } \\
\text { Gulf - TIDAL) }\end{array}$ & A & B & C & N/A & N/A & 4.0 & $6.5-9.0$ & $\mathrm{~N} / \mathrm{A}$ & 35 & 4 \\
\hline $\begin{array}{l}\text { LITTLE PECAN } \\
\text { BAYOU - TIDAL }\end{array}$ & & B & C & N/A & $\mathrm{N} / \mathrm{A}$ & 4.0 & $6.5-9.0$ & $\mathrm{~N} / \mathrm{A}$ & 35 & 2 \\
\hline HOG BAYOU & & B & C & 250 & 75 & 5.0 & $6.5-9.0$ & 500 & 32 & 4 \\
\hline
\end{tabular}

***chemical parameters and temperature = maximum values dissolved oxygen - minimum values

\section{*Bacterial Standards:}
**A = primary contact recreation
$B$ - secondary contact recreation
$C=$ propagation of fish and wildilfe
$D=$ domestic raw water supply

1 - fecal coliform content $\leq \log$ mean $200 / 100 \mathrm{ml}$; no more than $10 \%$ of samples exceed $400 / 100 \mathrm{ml}$

2 - fecal colfform content $\leq \log$ mean $1000 / 100 \mathrm{ml}$; no more than $10 \%$ of samples exceed $2000 / 100 \mathrm{ml}$

3 - monthly average of total coliform MPN $\leq 10,000 / 100 \mathrm{ml}$; monthly average of fecal collforms $\leq 2000 / 100 \mathrm{ml}$

4 - monthly total coliform median MPN $\leq 70 / 100 \mathrm{ml}$; no more than $10 \%$ of samples exceed MPN of $2 \overline{3} 0 / 100 \mathrm{ml}$

Source: Loulsiana Stream Control Commission, 1977 
wildlife" (Table 2-5). In the water quality segment which includes the proposed well site, there are six industrial users and no municipal users listed (Domingue, Szabo and Assoclates, Inc., 1975). No wild, natural and scenic, or recreational waterways have been designated in or near the study area (Louisiana Wildlife and Fisheries Commission, 1976).

\subsubsection{Floodplains/Wetlands}

As stated previously, the proposed project will be located on the existing Gladys McCall well site which is totally contained within an existing ring dike. Access will be via an existing board road. Although the existing Gladys McCall well site and access road lie within a floodplain and wetland area, no wetland areas will be disturbed by the project because all activities will be confined to the existing well site and board road. The USCE has reviewed this project and determined that no Department of Army permits related to activities in wetlands areas are required for this project (USCE, 1980). The wetlands areas are further described in sections 2.2.2.1, "General Basin Hydrology" and 2.3 "Flora and Fauna."

Expected flood hazard in the area of the well site is shown in Figure 2-5. Elevations in the wetlands (Decker, 1980) around the well site are at or near sea level. As shown in Figure 2-5, the storm surge generated by the 100-year flood event (a flood which has an average frequency of occurrence of once in 100 years, but can occur during any year or in consecutive years) in this area of the Louisiana coast is expected to reach a maximum elevation of approximately $3.8 \mathrm{~m}(12.6 \mathrm{ft}$ ) (F1gure 1-6) (USCE, 1970). Consequentiy the entire well site and surrounding area as far north as Grand Cheniere Ridge are subject to serious flood hazard. 


\subsection{Flora and Fauna}

The proposed well site lies about $3.7 \mathrm{~km}(2.3 \mathrm{mi})$ south of the Grand Cheniere Ridge and immediately west of Rockefeller Wildlife Refuge (Figure 1-3). Chabreck (1972) characterized this area as intermediate to brackish marshes with average salinities ranging from 5 to 15 ppt.

The study area is composed of marsh vegetation and open water interspersed with spoil banks in some areas. Marsh habitat existed in three different conditions depending on the local water regime. The proposed well site is located in the southeastern corner of a $7.7 \mathrm{sq} \mathrm{km}$ (3 sq mi) impounded marsh area. This impounded marsh contains a great deal of open water near the northern end, grading into broken brackish marsh at the southern end (Figure 2-7). The marsh outside this impoundment is also brackish, but unbroken and continuous. South of the impounded area there are two lakes, First Lake and Second Lake, connected by Hog Bayou. Water flows from the northeast toward the southwest through this area, excluding the impoundment and eventually flows into the Gulf of Mexico. Chabreck (1972) found the predominant brackish marsh vegetation to be wire grass (Spartina patens) and salt grass (Distichlis spicata;. A more complete list of plant species present may be found in Appendix B, Tables B-1- B-3. Cattle-grazing is an important land use practice in the Chenier Plain marshes. A dewatered marsh exists west of the continuous unimpounded marsh (Figure 2-7). Water level is also controlled in marshes to the east of the impounded area. This land is also used for pasture during part of the year. 


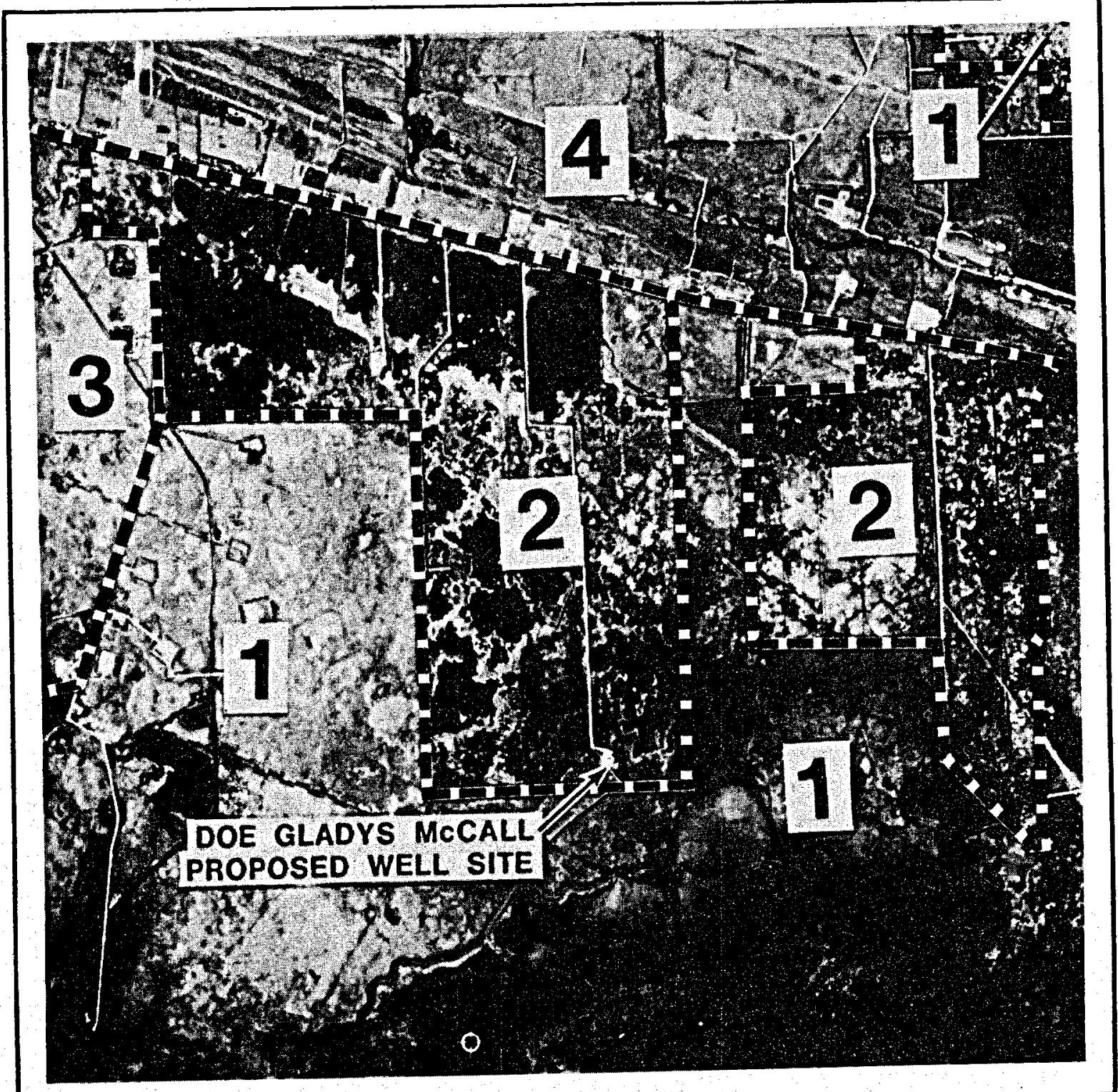

1 BRACKISH MARSH

2 IMPOUNDED BRACKISH MARSH

3 DEWATERED MARSH-PASTURE

4 CHENIERE RIDGE, PASTURE, FOREST VEGETATION

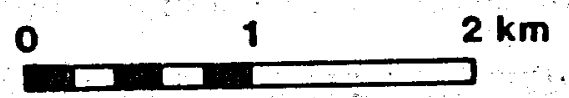

Figure $3-7$. Vegetation of the study area. 
The Chenier Plain marshes support a varlety of faunal species (Appendix B, Tables B-4-B-9), many of which are important to the recreation and economy of Cameron Parish. Louisiana is the leading fur-producing state in the United States, with nutria (Myocastor coypus) the most important furbearer (0'Neil and Linscombe, 1977). Research conducted at Rockefeller Wildlife Refuge has led to a managed comerical harvest of alligator hides (Alligator mississippiensis) in Cameron, Vermillion and Calcasieu Parishes. The offshore menhaden (Brevoortia patronus) and shrimp fisheries of Cameron Parish are important components of Louisiana's fish industry.

The study area lies within a system of wetlands which are used by a large number of bird species. Spring and fall mass migrations of northern nesting species pass through Cameron Parish annually (Lowery, 1974a); and as a result, Audubon Christmas Bird Counts from Cameron Parish record some of the highest number of species in the nation.

All marshes in Cameron Parish, including those in the study area, are important wintering grounds for waterfowl. The waterfowl resource in Cameron Parish was harvested at an average annual rate of 172,702 ducks and 36,978 geese between 1961 and 1970. Only one other county or parish in the United States annually harvests more ducks or geese (Carney et al, 1975).

\subsubsection{Terrestrial Flora and Fauna}

Terrestrial habitats in the study area are confined to spoil banks, the plank road leading to the proposed well site, and along Highway 82 on the Grand Cheniere Ridge. A list of plant species found in 
these habitats is shown in Appendix B, Tables B-2, B-3. Characteristic flora found on Superior Canal spoil banks in Rockefeller Refuge was reported to be predominantly wire grass and groundse1bush (Baccharis halimifolia) (Spindler and Noble, 1974). Likewise, spoil banks within the study area contain predominantly these species as well as marsh elder (Iva frutescens) and roseau cane (Phragmites communis). Groundse1-bush tended to occupy the higher sites and marsh elder the lower sites on the spoil banks. The roadsides contained a large variety of plant taxa (Appendix B., Table B-3). The dewatered marsh used as pasture was predominantly vegetated by saltgrass with some wire grass and, in the driest areas, marsh elder.

The spoil banks within the study area serve as habitat for both aquatic and terrestrial fauna. 01sen (1975) reported 14 bird species nesting on spoil banks in the intermediate marshes of Rockefeller Wildlife Refuge (Appendix B, Table B-5), six bird species nesting in the intermediate marshes in Rockefeller Wildlife Refuge (Appendix B, Table B-6), and 82 bird spectes utilizing the area at various times during the year. Most of the mammals Iisted in Appendix B, Table B-4, would probably utllize the terrestrial habitats in the study area. The speckled kingsnake (Lampropeltis getulus holbrooki) and the western cottonmouth (Agkistrodon piscivorus leucostoma) were two reptile species observed utilizing terrestrial habitat in the study area. Appendix B, Table B-7, 1ists other reptiles and amphibians whose range includes the study area. 


\subsubsection{Aquatic Flora and Fauna}

The majority of the study area is comprised of aquatic vegetation. Within the impounded area, wire grass, saltgrass and bulrush (Scirpus robustus) were the most common emergent species. A solid stand of softstem bulrush (Scirpus validus) occurred near the northern study area boundary. Widgeon grass (Ruppia maritima) was a noted submergent.

The natural marsh outside the impounded area also was comprised mostly of wire grass, saltgrass and bulrush. At the proposed well site, a bluegreen algae mat was noted, comprised mostly of Anabaena sp., Spirulina sp., Oscillatoria sp. and diatoms.

The aquatic fauna of the area would include a large number of $\mathrm{fish}$ species as noted by Perry (1976) and shown in Appendix B, Table B-8. Highly aquatic mammals possibly utilizing the area are nutria, muskrat (Ondatra zibethicus), river otter (Lutra canadensis) and the marsh rice rat (Oryzomys palustris). 01sen (1975) found six marsh nesting bird species in his study at Rockefeller Wildlife Refuge. These included the mottled duck (Anas fulvigula) and the black-necked stilt (Himantopus mexicanus). The Chenier Plain marshes are a very important wintering habitat for a large number of migratory waterfowl. A 1ist of those waterfowl species using the Rockefeller Wildlife Refuge and vicinity was comprised by Chamberlain (1957) and is shown in Appendix B, Table B-9. 


\subsection{Endangered Species}

The study area is included within the present or historical range of a few threatened or endangered species (Federal Régister, 1978). The only endangered animal species whose present range includes the study area is the red wolf (Canis rufus) (U. S. Department of Interior, 1978) (Figure 2-8). The historical ranges of the southern bald eagle (Haliaeetus leucocephalus) and peregrine falcon (Falco peregrinus) included the study area, and these birds could possibly occur in the area. The whooping crane (Grus americana) and the brown pelican (Pelecanus occidentalis) historically occurred in the area but neither exist there now. The American alligator (Alligator mississippiensis), a threatened species, does occur in the area.

One proposed endangered plant species, a skullcap (Scutellaria thieritti), could possibly occur in the area, although it was not noted during field observations. Definite ranges for endangered plant species have not been established in Louisiana.

\subsection{Noise}

\subsubsection{Ambient Noise}

The ambient or background noise level for the study area is typical of most of Louisiana's marsh areas far from noise sources of human origin. This level fluctuates between 40-45 dBA depending upon insects and atmospheric conditions (LDOTD, 1979). Near the road where the residences are, the noise level will be higher. A noise level of 50-55 dBA is not uncomon at the residences nearest to the well site. The source of this 


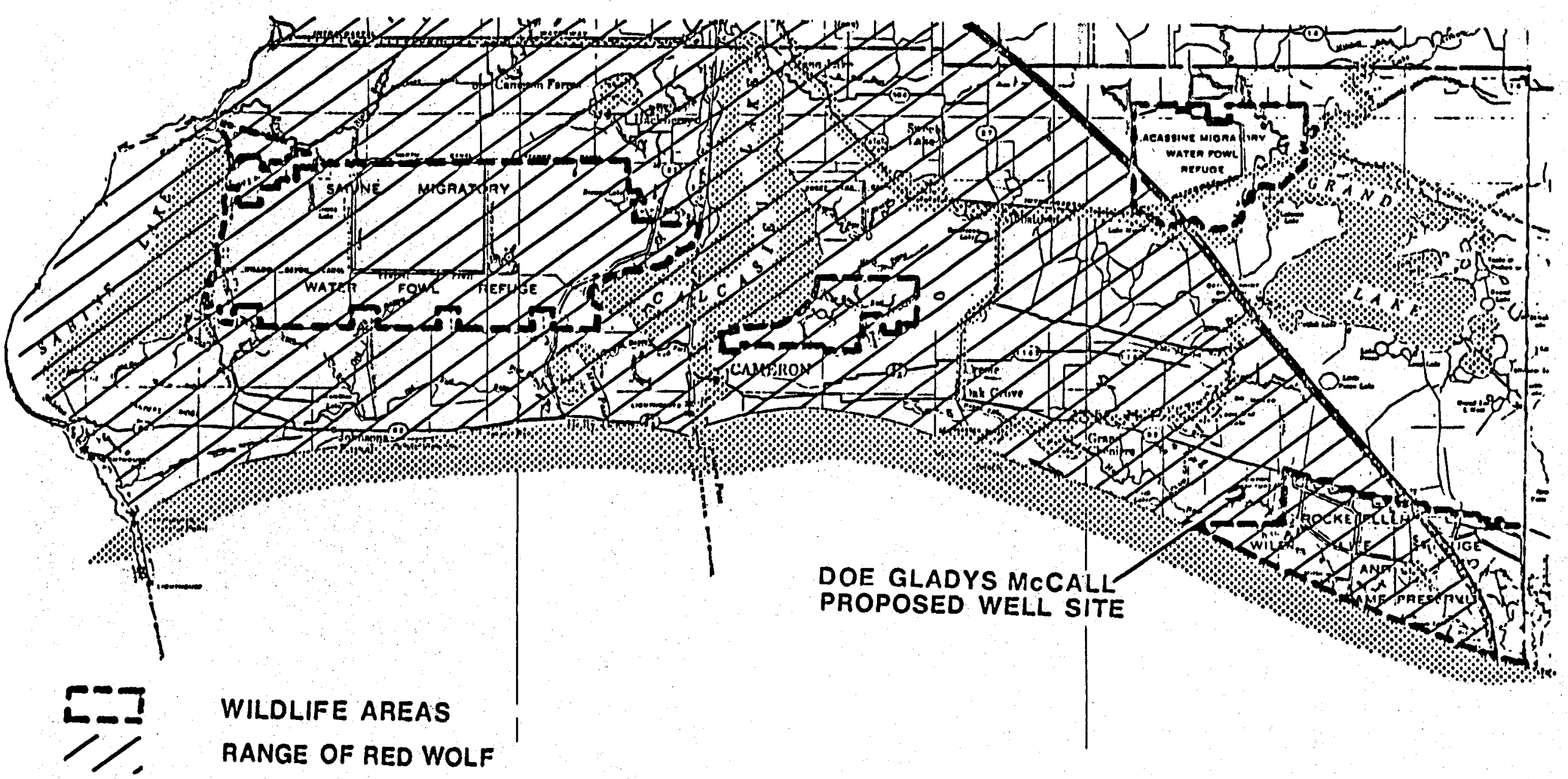

Figure 2-8. Recreational and wild11fe management areas and range of the red wolf in relation to the study area $\underset{\sim}{\tilde{\omega}}$
(USDI, 1978) 
noise is normal human activity associated with developed areas. As would be expected, the noise level during the night is lower than durring the daytime. Levels as low as 40-45 dBA are not uncommon in simflar lightly developed areas. Table 2-6 lists common sounds and their associated noise levels for comparison. Night-time noise levels in the marsh can be lower, sometimes as quiet as $35 \mathrm{dBA}$.

\subsubsection{Regulations}

The State of Louisiana has no specific guidelines concerning noise levels from geothermal activity. The Occupational Safety and Health Act (OSHA) set guidelines restricting the amount of noise workers are exposed to during any given perlod. The following levels were recommended as maximums for exposure without hearing protection (Table 2-7).

Table 2-7. Permissible Noise Exposure Without Hearing Protection. Duration per day (hours)

\section{Sound level (dBA)}

$\begin{array}{lr}8 & 90 \\ 6 & 92 \\ 4 & 95 \\ 3 & 97 \\ 2 & \\ 1 \frac{1}{2} & 100 \\ 1 & 102 \\ \frac{3}{2} & 105 \\ \frac{1}{4} \text { or less } & 110 \\ & 115\end{array}$

Source: Occupational Safety and Health Act, 1971

Since noise from machinery often fluctuates during a given time period, methods have been devised to quantify these fluctuating noise levels as a single number during a given time period. The most commonly used method is called the Equivalent Sound Level or Leq. This is a single 
Table 2-6. Common Sound Levels.

\begin{tabular}{|c|c|c|c|}
\hline Sound source & $\mathrm{dBA} A^{\star}$ & Response criteria & $\begin{array}{l}\text { Intensity } \\
\left(\mathrm{W} / \mathrm{m}^{2}\right)\end{array}$ \\
\hline \multirow[t]{3}{*}{ Carrier deck jet operation } & 150 & & $10^{\circ}$ \\
\hline & 140 & $\begin{array}{l}\text { Painfully loud: limited } \\
\text { amplified speech }\end{array}$ & $10^{8}$ \\
\hline & 130 & & $10^{7}$ \\
\hline Jet takeoff $(200 \mathrm{ft})$ & & Maximum vocal effort & \\
\hline \multicolumn{4}{|l|}{ Unmuffled geothermal well } \\
\hline & 120 & & $10^{5}$ \\
\hline \multirow[t]{2}{*}{ Discotheque } & & & \\
\hline & 110 & & $10^{5}$ \\
\hline \multirow{2}{*}{\multicolumn{4}{|c|}{$\begin{array}{l}\text { Jet rakeoff }(2000 \mathrm{ft}) \\
\text { Shout } 10.5 \mathrm{fd}\end{array}$}} \\
\hline & & & \\
\hline \multirow{3}{*}{ Heavy truck $(50 \mathrm{ft})$} & 100 & & 10 \\
\hline & & $\begin{array}{l}\text { Very annoying, hearing } \\
\text { camage }(8 \mathrm{hr})\end{array}$ & \\
\hline & 90 & & $10^{3}$ \\
\hline \multirow[t]{2}{*}{ Pneumatic drill $(50 \mathrm{tt})$} & & Annoying & \\
\hline & 80 & & $10^{2}$ \\
\hline \multicolumn{4}{|l|}{ Freight train $(50 \mathrm{ft})$} \\
\hline \multirow[t]{2}{*}{ Freeway traffic $(50 \mathrm{ft})$} & & $\begin{array}{l}\text { Telephone use difficult: } \\
\text { intrusive }\end{array}$ & \\
\hline & 70 & & $10^{1}$ \\
\hline \multicolumn{4}{|l|}{ Air concitioning unit $(20 \mathrm{ft})$} \\
\hline & 60 & & $\boldsymbol{1}$ \\
\hline Light anto traffic $(50 \mathrm{ft})$ & 50 & Quiet & $10^{-1}$ \\
\hline \multicolumn{4}{|l|}{$\begin{array}{l}\text { Living room } \\
\text { Bedroom }\end{array}$} \\
\hline & 40 & & $10^{-2}$ \\
\hline \multicolumn{4}{|l|}{ Library } \\
\hline Soh whisper (15 ft) & $\begin{array}{l}30 \\
20\end{array}$ & Very quiez & $\begin{array}{l}10^{-3} \\
10^{-4}\end{array}$ \\
\hline \multirow[t]{2}{*}{ Broadcasting studio } & 10 & $\begin{array}{l}\text { Just audible } \\
\text { Threshold of hearing }\end{array}$ & $10^{-6}$ \\
\hline & 0 & . & $10^{-6}$ \\
\hline
\end{tabular}

¿Typical A-veighted sound levels taken with a sound level meter and expressed as decibels on the scale. The " $A$ " scale approximates the frequency response of the human ear.

Source: Council on Environmental Quality, 1970. 
sound level which represents the mean of all the fluctuating sound levels over a given period.

Another descriptor is the day/night level of Ldn. This is a 24 hour equivalent sound level with a $10 \mathrm{dBA}$ penalty added to the nighttime noise levels in an effort to account for sleep disturbance. Both of these descriptors are used by the Environmental Protection Agency in their guidelines which are based on land use and activity as well as noise leve1. These guidelines are summarized in Table 2-8.

Table 2-8. Levels of Environmental Noise.

To Prevent Level Area

1. Hearing Loss Leq (24) $\leq 70 \mathrm{dBA} \quad$ All areas

2. Outdoor Activity Interference and Annoyance a. $\operatorname{Ldn} \leq 55 \mathrm{dBA}$

Outdoor residential and other areas where people spend varying amounts of time.

Outdoor areas where people spend limited amount of time.
Indoor residential areas. Other outdoor areas.

Source: Environmental Protection Agency, 1974 
The Department of the Interior has also published guidelines based on land use, as follows (Table 2-9):

Table 2-9. Noise Levels Not to be Exceeded:

Land Use Noise Level (dBA)

Daytime Evening Night

Industrial \& Geothermal

70

65

60

Business \& Commercial

65

60

50

Residential-Urban

60

55

45

Residential-Suburban

50

45

35

Residential-Rural

45

40

30

Agricultural

70

65

55

Recreational

45

40

30

Uninhabited or

70

65

60

Rangeland

*These noise level restrictions do not apply to this project. They are presented for informational purposes only.

Source: Department of the Interior, 1975

\subsection{Atmospheric Conditions}

\subsubsection{Regional Climatology}

The climatological station at Rockefeller Wildlife Refuge provides a first approximation for the study area. However, since this station does not have a 30 year normal, data from the long-term National Weather Service Station at Lake Charles are used. The most recent data for 1978 are 
used for this comparison. The study area is only $.17^{\circ} \mathrm{C}\left(.03^{\circ} \mathrm{F}\right)$ warmer, but the rainfall is about $28 \mathrm{~cm}$ (11 in) more at the site than at Lake Charles. In other words, temperature field between the site and Lake Charles is about homogeneous because the terrain in the southwestern section of Louisiana is located on the same flat level coastal plain as Lake Charles. Because the site is closer to the coast, it may be subject to more convective conditions. This is important in that more rainfall can increase the frequency of rainout or washout; $1 . e$. air pollutants at the site are more frequently cleaned out by the rain than at Lake Charles.

The region is humid subtropical with a strong maritime character. The climate is influenced to a large degree by the amount of surface water in the form of lakes, bayous, and flooded rice fields, and by the proximity of the Gulf of Mexico. Throughout the year these water bodies modify the relative humidity and temperature, decreasing the range between extremes. When southerly winds prevall, these effects are increased, imparting the characteristles of a marine climate. The summer months are consistently quite warm, but maximum temperatures rarely exceed $38^{\circ} \mathrm{C}\left(100^{\circ} \mathrm{F}\right)$ because of the uniformly high humidity of the dominant maritime tropical air mass and the moderating effects of cloudiness and the scattered convective showers and thunderstorms which are a primary feature of the weather during these months. The study area is also subject to infrequent but important polar influences during the winter as masses of cold alr periodically move southward across the plains states and out over the Gulf of Mexico. The winter months are narmally mild with cold spells usually of short duration. 


\subsubsection{Meteorology Near the Study Area}

Since the Rockefeller Wildlife Refuge Station measures only temperature and precipitation, other pertinent meteorological parameters are based upon the long-term measurements made at Lake Charles.

In the study area, prevaliing wind flow is from a southerly direction during most of the year. The flow of air from the Gulf of Mexico helps to temper extremes of summer heat, to shorten the duration of winter cold spells, and to provide a source of abundant rain. Winds are usually rather light. Almost $80 \%$ of hourly wind speed observations during the year are $6 \mathrm{~m} / \mathrm{s}$ or less.

Rainfall is heavy with the normal annual total near 1409 mo (55 in). Amounts are substantial in all seasons, although there is an early autum minimum in October. All other months except March produce an average of more than $100 \mathrm{~mm}$ ( $3.9 \mathrm{in})$, with the July total often more than 166 m (6.5 in). Almost all rainfall is of the convective and air mass types, showery and brief, except occasionally during winter when nearly continuous frontal rains may sometimes persist for a few davs.

Sumber relative humidity exceeds $80 \%$ for about 12 hours per day. High humidity may be experienced at any hour, but occurs mainly at night; 907 or more of the hours from late evening through early morning have relative humidity of $80 \%$ or higher. Readings of $50 \%$ or less occur about two hours per day, usually during afternoons; from 25 to $40 \%$ of midafternoon hours have had relative humidity of less than 502 . 
Thunderstorms occur each month. They are most frequent in July and

August with almost one-half of the days in each month reporting thunder; the fewest days with rain are in October. Severe local storms, including hailstorms, tornadoes and local windstorms, have occurred over small areas in all seasons, but occur most frequently during the spring months. Since 1900 the centers of four hurricanes have passed very near Lake Charles. The area has been affected by several other hurricanes, and also by a number of tropical storms which did not attain hurricane intensity. The strongest wind reported from 1940 through 1971 was $36 \mathrm{~m} / \mathrm{s}$ from the southeast in 1957. However, Lake Charles is in the region where a mean recurrence interval of 50 years gives a standardized extreme wind speed of $46 \mathrm{~m} / \mathrm{s}$ (90 mph). During such storms, precipitation may exceed 760-890 mn (30-35 in) over an area. The probability of hurricane-force winds in the study area during any year is about 7-8\% (USCE, 1976).

The atmospheric stability class is very important in the diffusion calculation; therefore Table 2-10 gives the pertinent information as a first approximation to be used in the impact computation insofar as the air quality due to the proposed action is concerned. Note that stability Class A represents extremely unstable conditions, B unstable, C slightly unstable, D neutral, E slightly stable, F moderately stable and G extremely stable (Slade, 1968). It is evident from the table that the combination of neutral and slightly stable conditions (D \& E) occupy about $62 \%$ of the year. For detailed diurnal variations of percentage of frequency of Inversion at Lake Charles, see Hsu (1977).

Since the concentration of pollutants is inversely proportional to the ventilation factor, $i$.e. the product of wind speed and mixing height (Hsu, 1977), during the warmer part of the year the pollutants are nearly twice as easily dispersed as in the winter season. 


\begin{tabular}{ccc} 
Table 2-10. $\begin{array}{c}\text { Percent Frequency and Wind Speed for Stability Classes as } \\
\text { Averaged between Taft, Louisiana and Houston, Texas }\end{array}$ \\
Stability Class & Percent Frequency & Average Wind Speed, m/s \\
\hline A & 6.4 & 4.0 \\
B & 2.4 & 4.3 \\
C & 4.8 & 4.2 \\
D & 32.2 & 4.1 \\
E & 29.4 & 3.0 \\
F & 14.3 & 1.7 \\
G & 10.5 & 1.3 \\
\end{tabular}

Source: DOE, 1980

\subsubsection{Air Quality}

Since the proposed well site has no air quality measurements and is located on the same flat coastal plain as the nearby Lake Charles, the air quality for the study area may be approximated from observations made at the Lake Charles area. Table 2-11 summarizes the existing air quality in the general area compared to the National Ambient Standards. For comparison purposes, measurements of carbon monoxide at Nederland and West Orange, Texas were also included in the table since these two areas are located in the same Air Quality Control Region, i.e., 106, as Lake Charles and the proposed well site (EPA, 19782). From Table 2-11 it can be seen that, except for ozone and nonmethane hydrocarbons, other pollutants as 1 isted and regulated by Federal and state agencies were within the primary standards. Since the site is a rural area it is expected that the pollution level is much less than that at Lake Charles. 
Table 2-11. Summary of Air Quality Data Observed in the Lake Charles Area as Compared to National Ambient Standards.

\begin{tabular}{|c|c|c|c|}
\hline Pollutant & Average Time & Primary Standards ${ }^{a}$ & Lake Charles Area \\
\hline Particulate matter & $\begin{array}{l}\text { Annual } \\
\text { (Geometic mean) } \\
24 \text {-hour }\end{array}$ & $\begin{array}{r}75 \\
260\end{array}$ & $\begin{array}{r}55^{\mathrm{C}} \\
154^{\mathrm{c}}\end{array}$ \\
\hline Sulfur oxides & $\begin{array}{l}\text { Annual } \\
\text { (Arithmẹtic mean) } \\
24 \text {-hour }\end{array}$ & $\begin{array}{r}80 \\
365\end{array}$ & $\begin{array}{r}26^{c} \\
108^{c}\end{array}$ \\
\hline Carbon Monoxide & 1-hour ${ }^{b}$ & 40 & $5.7^{\mathrm{d}}, 8.4^{e}, 7.5^{\mathrm{f}}$ \\
\hline Nitrogen dioxide & $\begin{array}{l}\text { Annual } \\
\text { (Arithmetic Mean) }\end{array}$ & 100 & $42^{c}$ \\
\hline $\begin{array}{l}\text { Photochemical } \\
\text { Oxidants, } \mathrm{O}_{3}\end{array}$ & 1 hour $^{b}$ & 160 & $282^{c}$ \\
\hline $\begin{array}{l}\text { Hydrocarbons } \\
\text { (Nonmethane) }\end{array}$ & $\begin{array}{l}3 \text { hour } \\
\text { (6 to } 9 \text { a.m.) }\end{array}$ & 160 & $185^{8}$ \\
\hline
\end{tabular}

a. Units are in $1 \mathrm{gg} / \mathrm{m}^{3}$ except for $\mathrm{co}$ which is in $\mathrm{mg} / \mathrm{m}^{3}$

b. Not to be exceeded more than once per year.

c. For the year of 1976 (data source: EPA, 1978a)

d. Measured by Louisiana Dept. of Highways at Westlake opposite industries about 200m from I-10 on Feb. 10, 1976 during Jan,-Feb. 1976.

e. Nederland, Texas, same as c, for comparison only

f. West Orange, Texas, same as e.

8. Measured by Louisiana Dept. of Highways at Cameron Evacuation Route in Cameron Parish at 11 a.m. on January 20, 1976. 
Due to the absence of sampling stations within the study area, the annual average air quality was predicted using the climatological Dispersion Model - CDM (EPA, 1973). Sulfur oxides were selected as the pollutants for the modelling effort because emissions from a geopressured test well are more likely to contribute to $\mathrm{SO}_{\mathrm{x}}$ levels than other pollutants for which standards exist (DOE, 1978). However, there are no. SOx emitters ( $\leq 1$ ton per year). As a result, the model predicts an $\mathrm{SO}_{\mathbf{x}}$ concentration of zero everywhere within the Rockefeller Refuge area (DOE, 1978).

\subsection{Unique Resources}

\subsubsection{Recreational Areas, Existing and Proposed}

The study area is located within the interior marsh areas of Cameron Parish and is surrounded by numerous natural and man-made bodies of water which are frequently used for recreational purposes such as hunting and fishing.

There are two National Refuges and one State Wildlife Refuge near the study area (Figure 2-8). The Lacassine National Wildlife Refuge, approximately $32 \mathrm{~km}(20 \mathrm{mi})$ north of the study area, offers 12,869 ha $(31,776 \mathrm{ac})$ for outdoor recreation, especially sport fishing and hunting on a seasonal basis. The Sabine National Wildlife Refuge, located approximately $37 \mathrm{~km}(23 \mathrm{mi})$ northwest of the study area, also offers ample opportunities for outdoor recreation. Its 57,853 ha $(142,846 \mathrm{ac})$, approximately 13,487 ha $(33,300 \mathrm{ac})$ of which is water, are used mainly for sport fishing, crabbing, seasonal hunting 
and bird watching. The Rockefeller State Wildlife Refuge, $3.2 \mathrm{~km}$ (2 mi) to the east, of the proposed well site, with its 23,670 ha $(58,445 \mathrm{ac})$ of marsh, shallow water impoundments, canals and bayous, is also a haven for sport fishermen and outdoor lovers.

There are no National or state parks, nor any scenic views within the study area. Although a State Preservation area has been proposed for Cameron Parish, its location has not been determined as yet. Grand Cheniere Park, comprising 1.6 ha $(4 \mathrm{ac})$ of large oak trees with a boat launching site and wharf with access to fishing, crabbing and swiming in the Mermentau River, is open to the public and is maintained by the Parish. The park is west of the study area. Recreational community centers along Highway 82 within the surroundings of the study area Include a baseball field and St. Eugene Church (Figure 2-9).

\subsubsection{Archaeological Sites}

Records on file at the Louisiana Division of Archaeology and Historic Preservation show no recorded prehistoric sites within the study area. The State Historic Preservation Office recently confirmed this fact (Carrier, 1979).

In addition, a cultural resources reconnaissance was conducted on May 8, 1979 in order to check for sites at the proposed well location and to interview local residents concerning posstble previous collections of artifacts or locally known sites within the study area. (The proposed well site lacks elevated locations suitable for prehistoric 


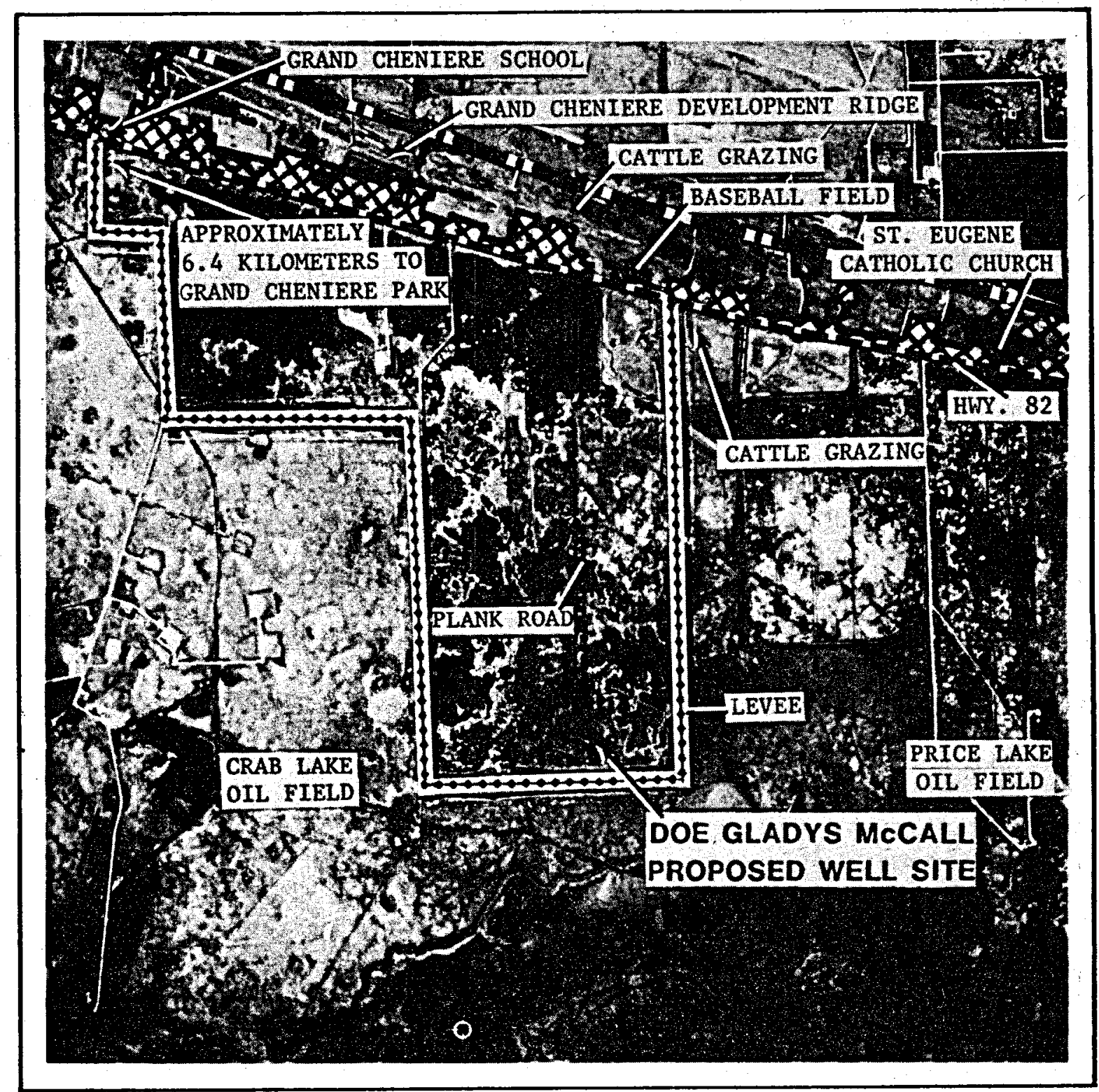

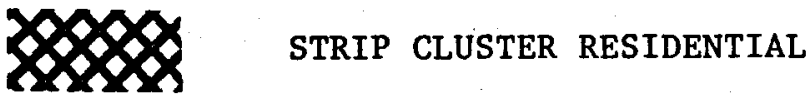
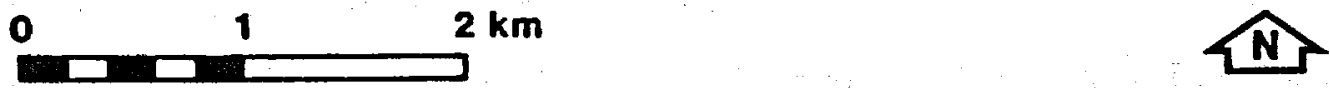

Figure 3-9. Land use map of the study area. 
habitation.) No prehistoric artifacts were evident on base soil surrounding the existing well site. Local residents on Grand Cheniere Ridge reported no finds of Indian mounds, pottery or stone tools within the study area.

The Chenier Plain region has been the subject of archaeological investigation since the late 1800s (Beyer, 1899; Collins, 1927; Ford and Quimby, 1945; McIntire, 1958). The Grand Cheniere Ridge belongs to the third oldest complex of ridges and has been available for occupation since about A.D. 850 (Gould and McFarlan, 1959). Two sites are located on the ridge outside of the study area, one of which (16 CM 10) was utilized between A.D. 850 and A.D. 1000. Because of the known occurrence of sites on Grand Cheniere Ridge, this location should be considered a high site probability area.

Burfed archaeological sites within the study area are unlikely, though not impossible. The west Louisiana continental shelf south of Cameron Parish displays evidence of a delta lake probably dating to the period around 12,000 years ago (Coastal Environments, Inc., 1977). Thus the several meter deep Chenier Plain organics, clays and silts may be underlain by deposits of an age suitable for contalning artifacts of the Paleo-Indian tradition or an earlier cultural tradition. (However, no artifacts have yet been found from these circumstances.) Since subsequent sea level rise inundated the study area until the formation of the present land surface during the past 1,000 years, buried sites of later periods are not expected. 


\subsubsection{Historical Sites}

No structures or locations listed on the National Register of Historic Places exist within the study area (Federal Register, 1979). Conversations with residents along Grand Cheniere Ridge confirmed that many structures were destroyed by Hurricane Audrey in 1957. Two houses apparently dating from the turn of the century to the early 1900s were observed. One is an apparently unoccupied two story structure she1tered by several large trees and bearing the name "Canik" on the mailbox. The Canik house is located on the north side of Highway 82, $0.64 \mathrm{~km}(0.4 \mathrm{mi})$ east of the existing plank road leading to the proposed well site. The second house was built in 1918 and was added on to subsequently, according to the current resident, Mrs. James Fawvor. Only the porch was destroyed during Hurricane Audrey. The house, located just to the west of the study area on the north side of Highway 82, is of cypress construction and is elevated on brick foundations. Although no structures dating to the mid to late 1800 s appear to remain standing in the study area, artifactual evidence of these historic farm sites undoubtedly exists. The present population of Grand Cheniere, as suggested by the family names of the early settlers, is of northern and southern European ancestory.

\subsection{Demographic and Socio-Economic Setting}

\subsubsection{Demography}

The population of Cameron Parish is $100 \%$ rural. In 1976, preliminary estimates of the parish population were 8,980 , representing a $-0.3 \%$ population change from the previous year (1975), when the population 
was 9,009 persons (Louisiana State Planning Office, 1977). The study area is within Ward 2 of Cameron Parish, which in 1970 had a population of 1,116 (PARC, 1973), representing an increase of $31.5 \%$ over the 1960 population (PARC, 1973.

There are no non-white communities within the study area. Population statistics for white and non-white persons show a small percentage of non-white population for the Parish (RARC, 1973).

The nearest populated comunity to the study area is the unincorporated town of Grand Cheniere, approximately $8 \mathrm{~km}(5 \mathrm{mi})$ west of the well site. Population for Grand Cheniere In 1960 was 1,166 persons. Population projections for the Parish and Grand Cheniere, the nearest comunity, show slow to moderate population growth (PARC, 1973). The nearest large population center is Lake Charles Standard Metropolitan Statistical area, which in 1975 had a population of 150,728 people.

\subsubsection{Ethnic Groups}

Anglo-Saxons were the first white group of people to settle Cameron Parish around the mid 1800s. They were followed by a group of French Canadians who arrived in the Parish in the late 1800s (PARC, 1973). Today this latter group constitutes the most dominant and culturally influential group. The Parish forms part of what is known as Acadian Louisiana (Bertrand, 1976).

\subsubsection{Socio-Economic Characteristics}

The major industrial employer in Cameron Parish during the 1960s 
and in 1970 has been the petroleum extraction industry. The second largest industrial employer in 1970 was agriculture. Although closely followed by the manufacturing industry, the combined service industries, including government, represent the biggest employer (PARC, 1973).

In 1969, median family income in Cameron Parish was $\$ 4,466.00$, ranking 17th among the state's Parishes. Median family income is expected to increase by the year 1980 to $\$ 11,500.00$; by 1985 it is expected to rise to $\$ 13,000.00$; and for 1990 it is forecasted to reach $\$ 14,600.00$ (ICRPDC, 1974). Per capita, personal income rose $24.5 \%$ in $1972(\$ 2,691.00)$ over the 1970 personal income $(\$ 2,161.00)$.

\subsubsection{Agricultural Economy}

Cameron Parish's main crops (valued at $\$ 7,250,000$ in 1974) are rice and soybeans--although cotton, sugarcane, hay, and other agricultural specialities, including livestock and commercial fishing, are important elements. Total cropland amounted to 26,606 ha $(65,693$ ac) in 1975 , of which 9403 ha $(23,217$ ac) $(23,216 \mathrm{ac})$ were accounted cropland, 16,127 ha $(39,820 \mathrm{ac})$ were in pasture, and 1076 ha $(2656 \mathrm{ac})$ were in other cropland (USCE, 1976).

According to a soil and water conservation committee 1979 draft study, the study area is part of the Mermentau-Vermillion-Teche Basin. Agriculture within the study area is pastureland (1620 ha [4000 ac]).

\subsubsection{Petroleum Extraction}

Minerals produced in Cameron Parish in order of value are: petroleum, natural gas liquids and sand and gravel. Also salt and shell are 
minerals produced in the Parish in lesser quantities. Natural gas and 011 production for 1970 in Cameron Parish was as follows:

Crude 011

Barrels

$16,275,000$
Condensate

Barrels

$9,807,400$
Casing Head \&

Natural Gas-MCF

$905,452,000$

Source: ICRPDC, 1974

Oil and gas fields are near the study area (Figure 2-9): Crab Lake Field ( 316 ha $(790 \mathrm{ac})$ ), which in 1975 produced 28,811 barrels of crude oil, 1,284 barrels of condensate and 46,392 MCF of dry gas; Price Lake Field ( 800 ha $[1200 \mathrm{ac}])$, which in 1975 produced 17,783 barrels of condensate and 594,479 MCF of dry gas; and little Pecan Lake (1872 ha [4680 ac]) (northeast of the study area), which in 1975 produced 18,949 barrels of crude oil, 188,171 barrels of condensate, and 10,356,159 MCF of casinghead gas. 


\section{REFERENCES}

Algermissen, S.T.

$1969^{\circ}$ Seismic risk studies in the United States. Paper presented at the January 13-18, 1969 meeting of the Fourth World Conference on Earthquake Engineering, Santiago, Chile.

Algermissen, S.T. and D.M. Perkins

1976 A probabilistic estimate of maximum acceleration in rock in the contiguous U.S. USGS open file report 76-416.

Baccigalopi, $W$.

1979 Personal communication, Rockefeller Wildlife Refuge.

Barrett, B.

1971 Cooperative Gulf of Mexico estuarine inventory and study, Louisiana, Phase II, Hydrology. Louisiana Wildlife and Fisheries Commission, New Orleans, Louisiana.

Bebout, D.G., R.G. Loucks, S.C. Bosche, and M.H. Dorfman

1976 Geothermal resources Frio Formation, Opper Texas Gulf coast. Geological circular 76-3, Bureau of Economic Geology, The University of Texas.

Bernard, H.A. and R.J. LeBlanc

1965 Resume of the quaterrary geology of the northwest Gulf of Mexico Province. In Quaternary of the United States, edited by H.E. Wright and D.G. Frey, pp. 137-185. Princeton University Press, Princeton, New York.

Bertrand, Alvin L.

1976 The demography of Louisiana: some implications for future planning. ISU A Zumi News 52:13-17.

Beyer, George E.

1899 Investigation of some shell mounds in Calcasieu Parish. The Louisiana Bistorical Society, Vol. II, Part 2.

Byrne, J.V., D.O. Leroy, and C.M. Riley

1959 The Chenier Plain and its stratigraphy, southwestern Louisiana. Gulf Coast Association of Geological Societies, Transactions Vol. 9, pp. 237-260.

Carney, S.M., M.F. Sorensen, and E.M. Martin

1975 Distribution in states and counties of waterfowl species harvested during 1962-70 hunting seasons. U.S. Department of Interior, Fish and Wildlife Service, Washington, D.C.

Carrier, E. Bernard

1979 Personal communication, Assistant Secretary - Department of Culture, Recreation and Tour1sm, Office of Program Development. 


\section{REFERENCES (continued)}

Chabreck, R.H. and A.W. Palmisano

1972 Vegetation, water and soil characteristics of the Louisiana coastal region. Louisiana State University Agriculture Experiment Station, Bulletin \#664.

Chamberlain, J.L.

1957 Ecological study of a Gulf Coast march, Rockefeller Refuge, Grand Chenier, Louisiana. Unpublished Ph.D. thesis, University of Tennessee, Knoxville.

Coastal Enviroments, Inc.

1977 Culture resources evaluation of the northern Gulf of Mexico continental shelf, prehistoric cultural resource potential. Vol 1. Coastal Enviroments, Inc., Baton Rouge,

Collins, Henry B., Jr.

1927 Archaeological work in Loulsiana and Mississippi. Smithsonian Miscellaneous Collections, explorations and fieldwork of the Smithsonian Institute in 1926, Vol. 78, No. 7.

Council on Environmental Quality

1970 Envirormental quality - the first annual report of the council on envirormental quality, transmitted to Congress, August, 1970.

Decker, C.W.

1980 Letter of April 29. Chief, Regulatory Functions Branch, Operations Division, New Orleans District, U.S. Army Corps of Engineers.

Department of Energy

1978 A preliminary environmental assessment of selected geopressuredgeothermal prospect areas: Louisiona Gulf Coast Region. Vol. II. Institute for Environmental Studies, Louisiana State University for U.S. Department of Energy.

1979 Department of Energy Gladys McCall proposed well site and geopressure testing program. Unpublished data on file, Department of Energy/Nevada Operations Office, Las Vegas, Nevada.

1980 Geothermal energy geopressure subprogram sweet Lake No. 1, Cameron Parish. U.S. Department of Energy, Washington, D.C.

Domingue, Szabo, and Associates, Inc.

1975 Water quality management plan; Mermentau-Vermilion-Teche basin. Prepared for Loulsiana Health and Human Resources Administration.

Engineer Agency for Resources Inventories

1973 Inventory of basic envirormental data, south Louisiana, Mermentau River basin to Chandeleur Sound, with special emphasis on the Atchafalaya basin. U.S. Army Engineer Topographic Laboratories, Washington, D.C. 
REFERENCES (continued)

Envirormental Protection Agency

1973 User's guide for the climatological dispersion model. National Enviroment Research Center, Research Triangle Park, North Carolina.

1974 Information on levels of environmental noise requisite to protect public health and welfare with an adequate margin of safety. Office of Noise Abatement and Control, Report No. 550/9-74-004.

1976 Quality criteria for water. EPA-440/9-76-023, Washington, D.C.

1978a Air quality data - 1976 statistics. Office of Air and Waste Management, Office of Air Quality Planning and Standards, Research Triangle Park, North Carolina.

1978b Pollution control guidance for geothermal energy development. EPA-600/7-78-101, Industrial Environmental Research Laboratory, Cincinnati, Ohio.

Ezernack, F.

1979 Personal communication, District Conservationist, Soil Conservation Service, Lake Charles, Louisiana.

Federal Register

1978 Endangered and threatened wildlife and plants. Department of the Interior, Fish and Wildlife Service, Vo1. 43, Part 17, p. 5803058039

1979 Annual listing of historic properties, National Register of Bistoric Places. Department of the Interior, February 6, 1979.

Fisk, H.N.

1948 Geological investigation of the Lower Mermantau River basin and adjacent areas of coastal Louisiana. Ms. on file, Mississippi River Conmission, Vicksburg, Mississippi.

Ford, James A. and George I. Quimby, Jr.

1945 The Tchefuncte culture, an early occupation of the lower Mississippi Valley. Memoirs of the Society for American Archaeology Vol. 10, No. 3, Part 2.

Gould, H.R. and E. McFarlan, Jr.

1959 Geologic history of the Chenier Plain, southwestern Louisiana. Transactions of the Gulf Coast Association Geological Society $9: 1-10$.

Gould, B.R. and J.P. Morgan

1962 Coastal Loulsiana swamps and marshlands - Field trip no. 9. In Geology of the Gulf coast and central Texas and guidebook of excursions, edited by E.H. Rainwater and R.P. Zingula, PP. 287341. Houston Geological Society, Houston, Texas. 


\section{REFERENCES (continued)}

Harder, A.H., Chabot KIlburn, H.M. Whitman, and S.M. Rogers

1967 Effects of ground-water withdrowals on water levels and salt-water encroachment in southwestern Louisiana. Department of Conservation and Louisiana Department of Public Works, Water Resources Bulletin No. 10 .

Hardin, G.C.

1962 Notes of Cenozolc sedimentation in the Gulf coast geosyncline, U.S.A. In Geology of the Gulf coast and central Texas and guidebook of excursions, edited by E.H. Rainwater and R.P. Zingula, PP. 1-15. Houston Geological Society, Houston, Texas.

Holdahl, S.R. and N.L. Morrison

1974 Regional investigations of vertical crustal movements in the U.S., using precise relevelings and mareograph data. Tectonophysics, $23: 373-390$.

$\mathrm{Hsu}, \mathrm{S}, \mathrm{A}$.

1977 Atmospheric dispersion characteristics in the Louisiana coastal zone. Coastal Studies Institute, Louisiana State University, Technical Report 229.

Imperial Calcasieu Regional Planning and Development Commission (ICRPDC)

1974 Population and economic base study. Imperial Calcasieu Regional Planning and Development Commission.

Jones, P.H.

1968 - Geochemical hydrodynamics - a possible key to the hydrology of certain aquifer systems in the northern part of the Gulf of Mexico basin. Proceedings: XXIII International Geological Congress, Symposizon $I I, 17: 113-125$.

1969a Hydrodynamics of geopressure in the northern Gulf of Mexico basin. Society of Petroleum Engineers, American Institute of Mechanical Engineers, and Journal of Petrolewn Technology, 21(7):803-810.

1969b Hydrology of Neogene deposits in the northern Gulf of Mexico basin. Louisiana Water Resources Research Institute, Louisiana state University Bulletin GT-2.

1970a Geothermal resources of the northern Gulf of Mexico. Geothermias (Special Issue 2) 2(1):14-26.

1975 Geothermal and hydrodynamic regimes in the northern Gulf of Mexico basin. Proceedings: Second U.N. Symposium on the Development and Use of Geothermal Resources Vol. 1:429-440. 


\section{REFERENCES (continued)}

Jones, P.H., A.N. Turcan, Jr., and Herbert E. Skibitzke

1954 Geology and ground-water resources of southwestern Louisiana. Department of Conservation, Louisiana Geological survey, Geological Bulletin No. 30.

Jones, P.H. and R.H. Wallace

1973 Hydrogeologic aspects of structural deformation in the northern Gulf of Mexico basin. In Structure of the Gulf Basin, Part I, pp. 89-115. New Orleans Geological Society.

Linsley, R.K. and J.B. Franzini

1972 Water resources engineering. McGraw-Hill Book Co., New York.

Louisiana Department of Transportation and Development

1979 Unpublished data, Baton Rouge, Louisiana.

Louisiana State Planning Office

1977 The State of the State. Louisiana State Planning Office, Baton Rouge, Louisiana.

Louisiana Stream Control Commission

1977 State of Louisiana water quality criteria. Louisiana Stream Control Commission, Baton Rouge, Louisiana.

1978 Louisiana water quality inventory. Louisiana Stream Control Commission, Baton Rouge, Louisiana.

Louisiana Wildlife and Fisheries Commission

1976 Louisiana'a natural and scenic streans system. Louisiana Wildlife and Fisheries Commission, New Orleans, Louisiana.

Lowery, G.H., Jr.

1974 Louisiana Birds. Louisiana State University Press, Baton Rouge, Louisiana.

McIntire, William G.

1958 Prehistoric Indian settlements of the changing Mississippi River delta. Louisiana State University Coastal Studies Series 1.

Muller, R.A.

1975 Freshwater potential in the Iouisiana coastal marshes and estuaries. Geoscience and Man, Vol. XII.

National Climatic Center

1977 Climatological data, anrual swmary with comparative data, Lake Charles, Louisiana. NOAA, Asheville, North Carolina.

National Climatic Center

1978 Climatological data, anmual sumary with comparative data, Lake Charles, Louisiana. NOAA, Asheville, North Carolina. 


\section{REFERENCES (continued)}

Newchurch, E.J., A.L. Bachmann, C.F. Bryan, D.P. Harrison, R.A. Muller, J.P. Newman, Jr., C.G. Smith, Jr., J.I. Balley, G.G. Kelly, K.C. Reibert 1978 A preliminary environmental assessment of selected geopressuredgeothermal prospect areas: Louisiana Gulf coast region. Institute for Environmental Studies, Louisiana State University, Envirormental Baseline Data, Vol. II.

Occupational Safety and Health Act

1971

Olsen, R.B.

1975 Bird usage of spoil banks in the intermediate marshes of southwestern Louisiana. Unpublished M.S. thesis, Louisiana State University.

0 'Neil T. and G. Linscombe

1977 The fur animals, the alizgator, and the fur industry in Louisiana. Louisiana Department of Wildife and Fisheries, New Orleans.

Perrin, William H.

1891 Southwestern Louisiana, biographical and historical. Gulf Publishing Company, New Orleans.

Perry, W.G.

1976 Standing crops of fishes of an estuarine area in southwest Louisiana, Proceedings: 30th Anrual Conference S.E. Association Fish and Wildiife Agencies 71-81.

Public Affairs Research Council

1973 Statistical Profile of Cameron Parish. Public Affairs Research Counciz of Louisiana, Inc.

Rollo, J.R.

1960 Ground water in Louisiana. Louisiana Department of Conservation and Department of Public Works, Water Resources Bulletin 1, Baton Rouge, Louisiana.

Slade, D.H., editor

1968 Meteorology and Atamic Energy. U.S. Atomic Energy Comission, Washington, D.C.

Soil Conservation Service

1978 List of soll mapping units that meet the criteria for Prime Farmland. Letter from Alton Mangum, State Conservationist, Alexandria, Louisiana.

Spindler, M.A. and R.E. Noble

1974 Fall vegetation on the spoil banks of Superior Canal, Cameron Parish, Louisiana. Louisiana Academy of Sciences 37:74-87.

U.S. Army Corps of Engineers

1970 Type 5 flood insurance study, Louisiana Gulf coast. Prepared for Federal Insurance Administration, USACOE, New Orleans District, New Orleans, Louisiana. 


\section{REFERENCES (continued)}

\section{U.S. Army Corps of Engineers}

1976. Final enviromental statement - Gulf intracoastal watemay: Petit Anse, Tigre and Carlin Bayous, and Bayou Grosse Tete, Louisiana. U.S. Army Corps of Engineers, New Orleans.

1980 Letter from R. J. Ventola, Acting Chief, Regulatory Function Branch, New Orleans District, USCE, to R. E. Oliver, USDOE, regarding permit requirements for the Gladys McCall project.

U.S. Department of the Interior

1975 Final erwiromental statement for geothermal leasing program. 4 vol.

v.S. Department of the Interior

1978 Bottom sediments, vegetation and endangered wildlife. Map on file at the Bureau of Land Management, New Orleans, Outer Continental Shelf office.

U.S. Geological Survey

1978 Water resources data for Louisiana, Coastal Louisiana, USGS Water-Data Report LA-78-3, Vol. 3.

Wallace, R.H.

1969 Abnormal pressures and potential geothermal resources in the Rio Grande embayment, Texas. LSU Proceedings: Second Symposium on Abnormal Subsurface Pressure 87-116

Warren, A.D.

1957 The Anahuac and Frio sediments in Louisiana. Transactions, Gulf Coast Association of Geological Societies VII:221-237.

Winslow, A.G., D.E. Hillier and A. N. Turcan

1968 Saline ground water in Louisiana. USGS Hydrologic Investigations Atlas HA-310.

Wintz, W.A., Jr., R.G. Kazmann, and C.G. Smith, Jr.

1970 Subsidence and ground-water offtake in the Baton Rouge area. Louisiana Water Resources Research Institute Bulletin 6, Louisiana State University, Baton Rouge, Louisiana.

Zack, A.L.

1971 Ground-water prompage and related effects, southwestern Louisiana, 1970 with a section on surface-water withdrawals. Louisiana Department of Conservation and Louisiana Department of Public Works Water Resources Pamphlet No. 27. 
CHAPTER THREE - PROBABLE IMPACTS - DIRECT AND INDIRECT

3.1 Impacts Due to Site Preparation and Construction

\subsubsection{Geology}

There are no geologically unique outcrops in the study area. No adverse impacts are expected to affect the geology of the region as a result of site preparation and construction.

\subsubsection{Physiography}

Surface elevations will be raised at the well site. The existing levee around the well site will be upgraded to facilitate drainage, to contain runoff, and to keep tidal waters out of the project area. Fill material for upgrading the levee and well pad will be obtained from low areas within the levee. Approximately 2 ha ( 5 ac) will be disturbed as a result of site preparation activities. The access road will be upgraded using boards and plastic. None of the wetland areas outside the ring levee will be disturbed.

\section{1 .3 So11s}

Disturbed sections of the levee will be small and are expected to revegetate quickly. Sedimentation outside the levee resulting from these modifications is not expected to be significant.

\subsubsection{Groundwater}

No adverse impacts are expected to the groundwater around the well site. .

\subsubsection{Surface Water}

Some pollutants, such as grease and oil, will spill onto the well site as a result of site preparation and construction operations. However, these w111 
be collected and pumped into the disposal well or transported to an approved disposal site. No adverse impacts are expected. The facility will not affect the natural function or character of the floodplain.

\subsubsection{Wildlife and Vegetation}

Wildlife will stay away from the well site during site preparation and construction. Adjacent wetlands will not be affected by the spills of oil, grease, and other substances which occur during site preparation and construction because all activities will occur within the upgraded levee system. The facility will have a minimum effect on wetlands because of the use of existing access routes and an existing well site.

\subsubsection{Land Use}

Land use along the upgraded access road and at the well site will not change from the existing energy-related activities.

\subsubsection{Socio-economic}

No adverse impacts are expected as a result of site preparation or construction.

\subsubsection{Air Quality}

No adverse impacts are expected on the air quality of the area. 3.1.10 Recreational, Archaeological and Historical Sites

No adverse impacts are expected.

3.1.11 Federal, State, Regional and Local Land Use Programs

Site preparation and construction will not affect any land use programs in the study area. 


\subsubsection{Noise}

When the well site, the levees, and the road are upgraded, there will be short-term noise increases attributable to the machinery active at the site.

\subsection{Impacts Due to Drilling and Maintenance}

\subsubsection{Geology}

There will be no effects of well construction on the physical geology of the study area.

\subsubsection{Physiography}

Drilling and maintenance at the proposed well site will not have a significant impact on the physiography of the study area.

\section{2 .3 Sol1s}

Drilling and maintenance at the proposed well site will not have a significant adverse impact on the wetlands soils of the study area. Erosion will not be a problem because no ground will be cleared and exposed to precipitation.

\subsubsection{Groundwater}

Groundwater use is not proposed during the Gladys McCall well test. It is likely that some brine, drilling muds and possibly hydrocarbons (fuel and lubricants) will be lost to the surface at the drill site, either by inadvertent spills or leakage from storage pits. Surface spills will permeate the soil during dry periods, but only to a shallow 
depth, due to the limited volumes likely to be spilled and the nearsurface water table conditions along the coast. Minor amounts of leakage are likely from the pits, even though they will be lined with an impermeable material. Whether the spill or leak is brine or fluid hydrocarbon, the effect will be long-lasting and difficult or impossible to remove. However, the impact will be small because:

1) the depth of contamination will be limited to near the surface;

2) the area of the spill should be limited to the drill site; and

3) in the case of a brine spill, the results are not significantly different from the natural introduction of brine in the area during storm tides.

Fresh groundwater resources of the Chicot aquifer, separated from the surface by more than $61 \mathrm{~m}$ (200 ft) of fine-grained deposits, should not be affected. The drill site is too remote from the chenier to cause impacts to these limited groundwater resources.

\subsubsection{Surface Water}

Potential impacts to surface water from drilling and maintenance are those associated with construction and development in any area. The fact that the proposed development will occur in an area of wetlands hydrology increases the environmental impact potential. However, the fact that the proposed action uses an existing well site in an area already extensively developed for similar activity minimizes the extent of further impacts to the existing environment.

There will be very limited alteration of existing surface water conditions. Road and drill pad upgrading, increased vehicular traffic and personnel population, ring levee upgrading, and other activities associated 
with development and maintenance of the well and well site will occur. Consequently, there will be increased runoff and increased turbidity and degradation of water quality and plant and animal habitat. Runoff from the construction site will contain oil and grease from vehicles and equipment and chenicals from drilling muds. However, this will be contained within the upgraded existing levee system.

Flooding of the well site is a significant threat, Site flooding could wash toxic materials into the surrounding marshes and waterways outside the ring levee where containment or recovery would be difficult or impossible.

\subsubsection{Wildlife and Vegetation}

The Gladys McCall well site is in a marsh area and most of the ecological impacts will involve aquatic flors and fauna. The extent of the impacts will in part depend upon the care and mitigation measures taken by the responsible personinel.

A plank road already running up to the well site will have some board resurfacing done. This is anticipated to cause only a temporary disturbance to wildlife and no disturbance to vegetation since the plank surface generates fittle dust; no water flow patterns will be changed and no new canals for spoil will be dug.

At the well site, an existing levee will be upgraded with the result that turbidity may be high in surrounding waters, temporarily lowering aquatic productivity. An impact will be loss of habitat inside this levee. The levee itself will support Iva spp., Baceharis halimifolia, etc. The habitat loss inside the levee will probably be direct and 
permanent, judging by the present system. Dust generated during levee or well construction may temporarily reduce photosynthetic activity in nearby vegetation (Treshow, 1970). Since the area affected is part of an impoundment, estuarine nursery fishery habitat will not be affected. Material for upgrading the ring levee will be taken from inside rather than outside the levee.

Nontoxic drilling muds will be used during this project. Drilling muds and chemicals are to be reinjected. After the test is completed, all waste material will be transported to and disposed of in a landfill in accordance with local, state, and Federal regulations.

Noise and activity during site drilling and maintenance may scare away mobile fauna. Thus, hunter success and the quality of the recreational outing near the proposed action may be lessened for the duration. of the well's use.

Construction of a powerline to the well site, if necessary, may cause some habitat displacement and generate dust, noise and oil and grease from vehicles. The powerline would cause the least harm if placed along the plank road where only quickly growing roadside vegetation would be displaced. Pumping water into the site for drilling fluid, cement and cleanup could cause some turbidity and noise; however, this would cause only a local, temporary lowering of productivity.

No adverse impacts are expected on endangered or threatened species whose range includes the study area.

\subsubsection{Land Use}

The area is presently occupied by a well site (the original Gladys McCall well site) and an access plank road. As a result of the existing and 
previous use of this area, dirẹct impacts will be minimal. Residential and commercial land uses are located about $3.7 \mathrm{~km}(2.3 \mathrm{mi})$ away, and thus are not near the proposed action.

\subsubsection{Socio-economic}

The proposed action is not expected to impact the socio-economic characteristics of the area either adversely or beneficially, since drilling operations exist throughout the region. The expected work force will consist of about 30 to 50 people who will probably commute into the area for the time of construction and testing operations.

\subsubsection{Alr Quality}

During the exploration phase, air pollutants will be emitted by vehicles, drill rigs, and construction equipment (e.g., tractors, generators, compressors) (DOI, 1978). Exhaust emissions from drilling and construction machinery will include $\mathrm{SO}_{2}, \mathrm{SO}_{\mathrm{X}}, \mathrm{CO}$, hydrocarbons, and particulates. Diesel drives for the drilling rigs typically consume $2,0001 / \mathrm{da}(550 \mathrm{gal} / \mathrm{da})$ of fuel, resulting in emissions of approximately $23 \mathrm{~kg} / \mathrm{da}(51 \mathrm{lbs} / \mathrm{da})$ of $\mathrm{co}, 9 \mathrm{~kg} / \mathrm{da}(20 \mathrm{lbs} / \mathrm{da})$ of exhaust hydrocarbons, $107 \mathrm{Kg} / \mathrm{da}(236 \mathrm{lbs} / \mathrm{da})$ of $\mathrm{NO}_{\mathrm{X}}, 7 \mathrm{Kg} / \mathrm{da}$ (15 $\left.1 \mathrm{bs} / \mathrm{da}\right)$ of $\mathrm{SO}_{\mathrm{X}}$, and $7.5 \mathrm{~kg} / \mathrm{da}(171 \mathrm{bs} / \mathrm{da})$ of particulates (ERDA, 1976). The emissions associated with the operations of diesel-powered equipment for five days to prepare a well pad would be equivalent to those associated with a single day of drilling. A small amount of polluting emissions will also result from the operation of delivery trucks and private vehicles. These releases are expected to be minor and short-term, and should be readily dispersed because about $62 \%$ of the time the atmosphere stability classes are in $D$ and $E$ (see Section 2.6.2). The accumulated 
level of Impacts due to exhaust emission from drilling and construction machinery will be negligible. Because the concentration of total suspended particulates in the air at Lake Charles is within national ambient standards (see Section 2.6.3), the added effect on air quality due to construction will be minimal.

\subsubsection{Recreational, Archaeological and Historical Sites}

There are no known prehistoric or historic cultural resources in the area of the proposed action. There will not be any direct or indirect impact expected from the construction or testing operations of the proposed action upon any existing or proposed recreational sites. The nearest recreational facility, a baseball park, is approximately $3.7 \mathrm{~km}(2.3 \mathrm{mi})$ from the Gladys McCall proposed well site.

\subsubsection{Federal, State, Regional and Local Land Use Programs}

None of the agencies contacted which responded foresee any conflicts with the proposed action. The proposed action would have to comply with some of these agencies' rules and guidelines relating to construction and operation activities (Chatper 6). Thus, no adverse impacts on land use programs are expected to occur as a result of the proposed action.

\subsubsection{Noise}

Noise data gathered by the Radian Corporation (1979) and the Bureau of Economic Geology, the University of Texas at Austin in 1978, on a 2100-horsepower drilling rig indicate that noise generated by this rig is approximately equal to the noise levels anticipated to be generated by the drilling of the wells at the Gladys McCall proposed well site. 
Noise levels generated by the drill rig were loudest perpendicular to the engine exhaust, not in the direction of the exhaust. During a twohour time period, they found the loudest nolse from the drill rig to be as follows:

$\begin{array}{ll}\text { at } 31 \mathrm{~m}(100 \mathrm{ft}) & 89 \mathrm{dBA} \\ \text { at } 91 \mathrm{~m}(300 \mathrm{ft}) & 78 \mathrm{dBA} \\ \text { at } 183 \mathrm{~m}(600 \mathrm{ft}) & 65 \mathrm{dBA} \\ \text { at } 275 \mathrm{~m}(900 \mathrm{ft}) & 56 \mathrm{dBA}\end{array}$

Figure 3-1 depicts the anticipated noise level produced by the drilling rig in the Ldn metric as derived from the Radian Corporation data. Thus, the noise level from the drilling operation should return to the ambient level well before it reaches the nearest receptor. Excess attenuation, above that shown, may be achieved by the marsh vegetation in the area. Because no data are available concerning the precise orientation of the drill rig exhaust, the worst case was assumed in Figure $3-1$, that is the case with the loudest direction pointing at the closest developed area.

A11 current noise regulations are based to some degree on the land use of the receptor area. Those land uses most likely to be affected by increased noise levels are called sensitive receptors. A sensitive receptor can be defined as a land use whose primary function is devoted to an activity where quietude is a critical factor of use. Such sensitive receptors could Include churches, hospitals, rest homes and certain parks. Some animals may also be considered sensitive receptors. However, a survey of the project area and current literature revealed no fauna in the study area known to be permanently affected by the noise. Likewise, the nearest land use sensitive receptors are too far from the proposed well site to be adversely affected by the Increased noise levels. 

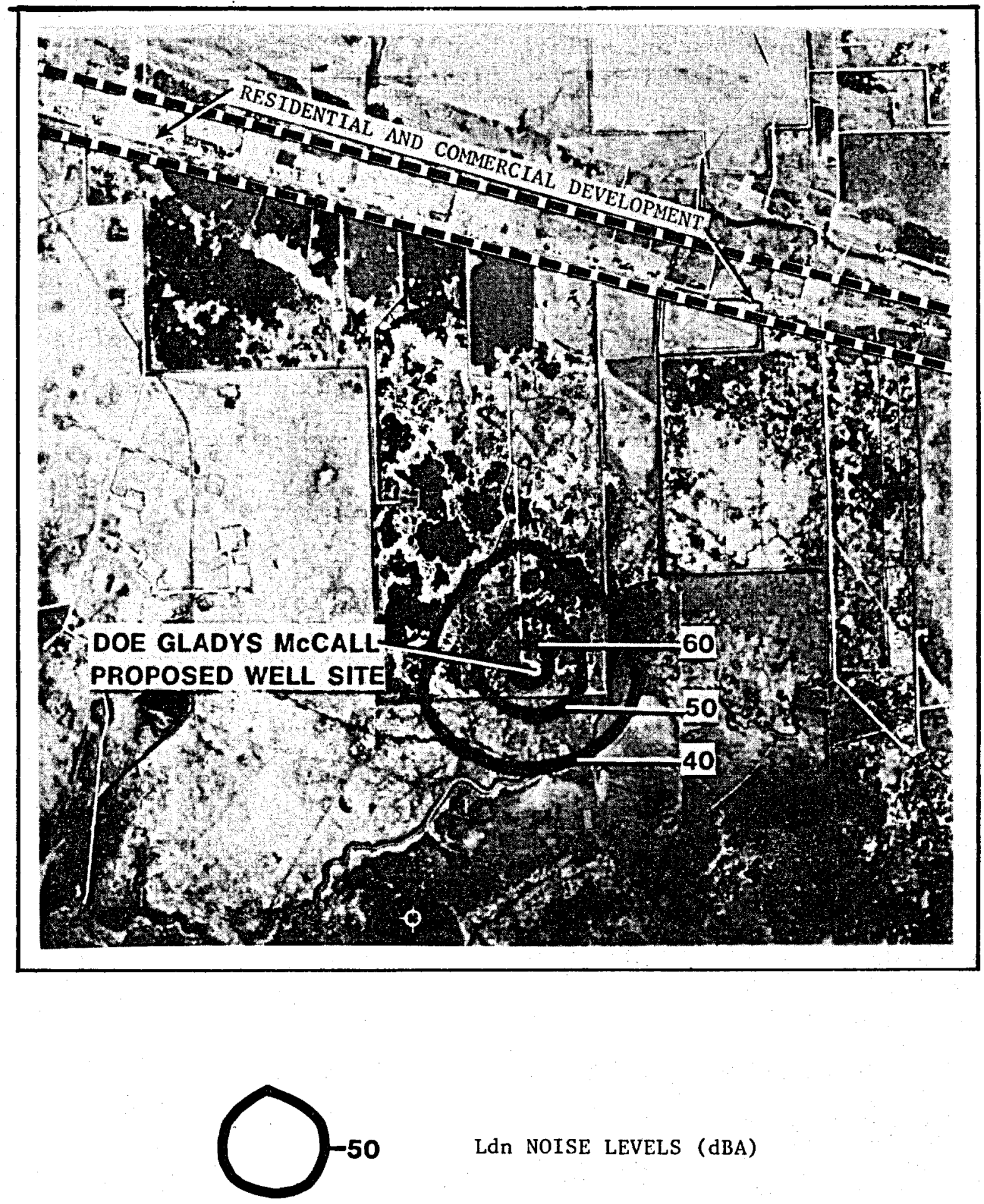

Ldn NOISE LEVELS (dBA)
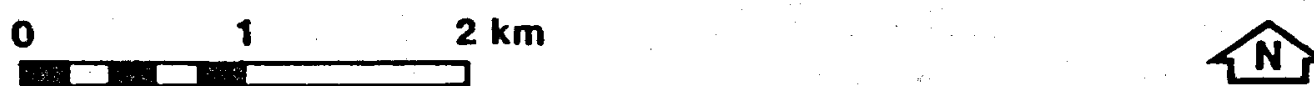

Figure 4-1. Noise contours resulting from normal operation of a drilling rig. (Radian Corporation, 1979). 


\subsection{Impacts Caused by Flow-testing or Operation of the Proposed Action}

\subsubsection{Geology}

The possible environmental impacts of geopressured geothermal resources development have been identified as: 1) land subsidence, and 2) contamination of, or hydraulic effects upon (a) the surface environment in the vicinity of the well site; or (b) the subsurface environment, consisting of both fresh and saline aquifer systems in the vicinity of the well site. All such impacts would be of a secondary nature, occurring as a consequence of fluid withdrawal, or fluid escape, from formations in the geopressure zone.

Land-surface subsidence as a result of fluid production from the subsurface is a complex hydrodynamic phenomenon related to the drainage function of fine-grained sediments, mainly swelling varieties of clay. Drainage of fine-grained sediments is closely controlled by the geometry of sediment facies distribution in the zone of hydraulic stress, the salinity and temperature of formation waters set in motion by the hydraulic stress and the effects of structural deformation, mainly faults, as subsurface hydraulic barriers. Faults in the Louisiana Gulf coastal plain reflect natural hydrodynamic effects, their location and the movement on them being mainly the consequences of differential compaction of sandy sediment facies and adjacent clayey sediment facies, in response to progressive compressive stress due to increasing overburden load concurrent with continuing prograding deltaic deposition. Movement on such faults is likely to be renewed if the pressure of interstitial fluids in the fine-grained sediments is reduced, resulting in effective 
stress differentials greater than any the sediments have previously experienced. Reactivation of movement on existing faults as a consequence of compressive stress induced by removal of fluids from the subsurface by wells is common in the Gulf coastal plain of Texas, and is evident in a few localities in Louisiana. All such movements are attributable to fluid pressure declines in reservoirs of the hydropressure zone only.

Susceptibility of any locality to land subsidence, as a consequence of fluid withdrawal from reservoirs in the hydropressure zone, is related to the hydrologic history of the locality and of the region in which it occurs. If the deposits in a coastal area have been preconsolidated by loading stress -- either as a consequence of Pleistocene lowering of sea level, deep trenching by rejuvenated coastal streams and lowering of the water table by several hundreds of meters below its present "static level," or by natural water level decline before fluid withdrawals through wells -- then there will be no subsidence of the land surface until the head of water in these deposits is lowered by pumping below the level reached in the geologic past. The Holocene deposits, which overlie the Pleistocene deposits at the test site, have not been pre-stressed by natural drainage, and are highly susceptible to compaction as a result of fluid withdrawal and consequent head decline. Land subsidence from fluid withdrawal is common where Holocene deposits are affected. However, withdrawal of fluid from the hydropressure zone is not anticipated during the Gladys McCall test and therefore land subsidence from this source will not occur. 
Deposits in the geopressure zone occur within a natural pressure vessel; interstitial fluid pressure reflects part, or all, of the weight of overlying deposits. Beneath a regionally extensive "seal," now mapped in considerable detail in the Gulf coastal plain, geopressure conditions extend downward thousands of meters - perhaps to the zone of rock metamorphism at depths of 10,675 to $12,200 \mathrm{~m}(35,000$ to 40,000 ft). The depth to the top of the geopressure zone ranges from about 2,440 to $5,490 \mathrm{~m}(8,000$ to $18,000 \mathrm{ft})$ in south Lous1ana. The top of the geopressure zone is at a depth of about $4,575 \mathrm{~m}(15,000 \mathrm{ft})$ in the vicinity of the proposed action. Sandbed aguifer systems occur in the geopressure zone thousands of meters below the pressure seal, and fluid pressure declines resulting from large scale withdrawals from such aquifers commonly reduce reservoir pressures to hydrostatic, or below. However, the fluid pressure "envelope" in which these zones of low fluid pressure occur is unbroken, and no upward transmission of the zone of pressure relief is yet apparent. There is no welldocumented example of land subsidence in coastal Louisiana resulting from withdrawal of fluids from reservoirs in the geopressure zone some 6,600 of which have produced some 6 Tcf of natural gas each year, for more than a decade. Some of these reservoirs have also produced millions of barrels of saltwater with the gas.

If production wells are properly constructed, negative impacts are not Iikely on the physical geology in the vicinity of the proposed well site. These improbable negative Impacts could be contamination, or hydraulic effects upon the land surface or the subsurface environment. Pressure relief as a function of fluid production tends to close, rather than open, fault planes; well design will preclude serious thermal 
effects on the near-surface rock environment; and suitable disposal wells will return spent brines to regional saline aquifer systems.

Effects of the short-term flow testing on the physical geology of the well sites are those resulting from fluid pressure changes in the reservoirs tapped by the wells. Short-term flow tests involve relatively small total volumes of produced fluids, compared to the volumes of fluid withdrawn during commercial operations on an annual basis; for example. Detailed records for wells and well fields which have produced from geopressured reservoirs comparable to the proposed test of the Gladys McCall well site indicate that no adverse environnental consequences should result from short-term flow testing. Geopressured gas fields in south Louisiana are known to have produced more than 100 million barrels of liquid equivalent ( $1,000 \mathrm{cu} \mathrm{ft}$ of gas equals one barrel of liquid) over periods as great as 10 years with no measurable subsidence. By comparison, the proposed Gladys McCall well test will produce at about the same rate (nearly 10 million barrels per year) but for a two-year period. Wallace (1962) provides records of production, $\mathrm{Pz}$ (where $\mathbf{P}=$ Pressure, and $z=$ coefficient of expansion of gas) versus cumulative production, and cumulative water production, for numerous geopressured gas reservoirs in south Louisiana--some of which developed reservoir pressures less than hydrostatic without observable land subsidence. On this basis, it may be several decades before subsidence, if it occurs, is manifested at the surface due to a geopressured test well.

\subsubsection{Physiography and Soils}

Because there is no projected adverse geologic impact on the study area, there will be no adverse impact on the physiography or soils. 


\subsubsection{Groundwater}

During normal operating conditions, groundwater would not be impacted by flow testing, with the exception of normal amounts of surface contamination of soils from inadvertantly lost brine, either from flow systems or storage pits. The 1mpacts will be limited in area and will not affect fresh groundwater in the Chicot aquifer or the limited groundwater supplies of the cheniers.

\subsubsection{Surface Water}

The surface water from this stage of the proposed action is not expected to be impacted because no fluids or foreign substances will be released into the surface water.

\subsubsection{Wildlife and Vegetation}

Potential impacts directly generated by the flow-testing are those from Iiquid and gaseous effluents and noise. Potential impacts indirectly associated with testing and operation are exhaust fumes and noise from increased traffic to the well site.

Geothermal effluents might cause adverse biological impacts if released into the environment. Proper containment, insulation and disposal (reinjection) of the geopressured products from flow testing and opertion should assure a minimal effect on plant and animal 1ife.

Well testing will result in release of gases such as $\mathrm{CO}, \mathrm{NO}_{\mathrm{X}}, \mathrm{CH}_{4}, \mathrm{NH}_{\mathrm{S}}$, $\mathrm{N}_{2}, \mathrm{SO}_{X}$, and $\mathrm{H}_{2} \mathrm{~S}$. It may be necessary to flare uncondensable geopressured gases instead of reinjecting them. This may cause local increases in $\mathrm{H}_{2} \mathrm{~S}, \mathrm{SO}_{\mathrm{X}}, \mathrm{N}_{2}, \mathrm{NH}_{3}, \mathrm{CO}_{2}$ and $\mathrm{H}_{2} \mathrm{SO}_{4}$ levels. Borate may cause some leaf damage to exposed plants (Weres et al, 1977). 
Sufficiently high $\mathrm{H}_{2} \mathrm{~S}$ concentration might lead to local acidification of water, which may in turn solubilize trace heavy metals. This would be of particular concern inside the ring levee where ponded water is already high in metals. Acidification inside the ring levee could increase corrosion rates and accentuate the problem. Sulfur oxides and $\mathrm{H}_{2} \mathrm{SO}_{4}$ can be highly toxic to vegetation and aquatic communities, but will have only a very local effect.

Noise from flow testing and increased traffic might temporarily cause animals to move away from the well site. If testing or operation occurs during the waterfowl hunting season, hunter success or the quality of the outdoor recreational experience might be lessened. Automotive exhaust from increased traffic may temporarily decrease vegatative productivity along the roadside. No adverse impacts are expected to affect the Rockefeller Wildlife Refuge.

\subsubsection{Land Use}

No impacts are expected upon land use of the area from the proposed action.

\subsubsection{Socio-economic}

The socio-economic character of the study area is not expected to be adversely impacted by the proposed action.

\subsubsection{Air Quality}

Well-testing will result in the direct release of steam and a variety of gases and particulates. The contaminant of greatest concern is 
hydrogen sulfide. No data are presently available on the hydrogen sulfide concentration in the Frio Formation in this project area. Hydrogen sulfide concentrations for the Frio along the Gulf coast in Texas range from $.32 \mathrm{mg} / 1$ to $1.6 \mathrm{mg} / 1$ (Kharaka et al., 1977). Concentrations from geopressured zones in the Frio in Vermilion Parish near the Gladys McCall well site range from $.4 \mathrm{mg} / 1$ to $.5 \mathrm{mg} / 1$ (Kharaka et al., 1979). The $\mathrm{H}_{2} \mathrm{~S}$ concentrations at the project will probably be between those values shown in Table 3-1. Hydrogen sulfide levels will be monitored in order to determine if a significant impact will occur. No Louisiana or Federal air standards for hydrogen sulfide presently exist. The $\mathrm{H}_{2} \mathrm{~S}$ odor threshold is $.002 \mathrm{mg} / 1$.

Table 3-1. Hydrogen Sulfide Concentrations in the Frio Formation.

We11

Kitchen 1

Cozby $\$ 2$

Gardiner \#1

Rachel $\$ 66$

St. Un. A 19

Edna Delcamkre

No. 1
Field

Chocolate Bayou Chocolate Bayou Chocolate Bayou East White Pt. Weeks Is land

Tigre Lagoon
County or Parish

Brazoria, Tex.

Brazorla, Tex.

Brazorla, Tex.

San Patrizio, Tex.

Vermilion, La.

Vermilion, La.
$\mathrm{H}_{2} \mathrm{~S}$ Concentration
$\mathrm{mg} / 1$

$1.6^{\mathrm{a}}$

$.85^{\mathrm{a}}$

$.32^{a}$

$1.0^{a}$

$.4 \mathrm{~b}$

$.5^{\mathrm{b}}$

$\begin{aligned} & \text { Source: } \text { Khataka et al., } 1977 \\ & \text { Kharaka et al., } 1979\end{aligned}$

Other gases that may be omitted are $\mathrm{CO}, \mathrm{NO}_{2}, \mathrm{NH}_{3}, \mathrm{CN}_{4}, \mathrm{~N}_{2}$, and $\mathrm{H}_{2}$. based on typical noncondensable gas content for pressure fluids. Tarticulates released with the geopressured fluids or raised by equipment should not add significantly to the background level of particulates in the proposed well site area. The short duration of these emissions makes it unlikely that the air quality will be significantly affected outside of the Immediate area of the well. 
The impact of flaring the gases from a single plume is expected to be small, based on the experfences from similar geopressured well tests (ERDA, 1977). This particular project is miniscule when compared to the many flares which exist in major refineries in the Lake Charles area where the air quality is still within national ambient standards (see Section 2.6.3) (DOE, 1980).

The impact of the cooling device is expected to be negligible because of the small size required for the single well operation. A possible impact would be the increased occurrence of fog (or the formation of "steam fog" during freezing temperatures in winter; but the frequency of this is small, since the mean number of days with temperature equal or less than $0^{\circ} \mathrm{C}\left(32^{\circ} \mathrm{F}\right)$ as observed at Lake Charles is approximately 13 days per year).

Noncondensable geopressured gases will be released during drilling (ERDA, 1976). Although the weight of the drilling mud should prevent a large release of gases to the surface during drilling, the mud will carry some gases to the surface. These gases will be released to the atmosphere from the water/steam separator at the well, from the drilling-mud cooling tower, and from the liquid sump. Maintenance of sufficient pressure within the well to protect against blowouts should result in acceptably low levels of gaseous emissions during drilling. Impact on air quality due to blowout will be discussed later.

\subsubsection{Recreational, Archaeological and Historıcal Sites}

There are no known prehistoric or historic cultural resources in the area of the well site. 
None of the designated recreational areas will be adversely impacted by the construction or operation of the proposed testing activities. Hunting in the vicinity of the well site and road will decrease as a result of the proposed action.

\subsubsection{Federal, State, Regional and Local Land Use Programs}

No adverse impacts will result from the proposed action upon any known or proposed Federal, state, regional or local land use programs.

\subsubsection{Noise}

Any venting of gases during flow testing of the proposed well will not be muffled. An unmuffled, venting geothermal well will produce about $120 \mathrm{dBA}$ at 31 m $(100 \mathrm{ft})$ from the well head. This is $30 \mathrm{dBA}$ higher than the loudest drilling noise and will be used as the upper limit of noise produced by this project. In this event, the noise level at the nearest residence, $3.7 \mathrm{~m}(2.3 \mathrm{mi})$, will be $57 \mathrm{dBA}$. At $7 \mathrm{~km}(4.3 \mathrm{mi})$, the noise level from a venting unmuffled geopressured well will drop to 30 dBA. These levels cannot be considered a hazard, nor would this condition exist for a considerable length of time. Thus, the impact of noise from flow-testing of the well is negligible.

\subsection{Impacts on Floodplains and Wetlands}

According to the avallable information, the Gladys McCall well site will be inundated by the 100-year flood. Alternatives to prevent the flooding of the well site are 1) raising the height of the surrounding dikes and 2) relocating the site outside of the floodplain. The height of the dike may be increased by either placing new material on top of the 
dike or replacing the existing dike with a higher one. The addition of material to the dike to ralse its height would result in the compaction of the underlying organic materials and clays and the subsidence of the dike. Expanding the width of the base of the dike may spread the load sufficiently to eliminate subsidence but would require new construction activities in the adjacent wetlands. Removing the existing dike and replacing it with lighter weight materials that would effectively "float" on the organic materials and clays would require new construction activities in the adjacent wetlands and could adversely affect the wetlands ecosystem.

As indicated in previous environmental assessments prepared for the Geopressured Geothermal Energy Subprogram (ERDA, 1977; DOE, 1980), the surface overlay zone for the geopressured resource is frequently located in the coastal areas of Texas and Louisiana. Portions of the prime prospect or fairway may lie outside the floodplain; however, technical considerations, such as location relative to geologic structure and sediment depocenters and the locations of available leases, require that the well be located in the floodplain. In this case, locating the well on an existing well site significantly reduces impacts to the adjacent wetland areas. Also, since the height of the existing dike will not be increased, the hydraulic conductivity of the floodplain will be unchanged.

As stated previously, all construction activities will be confined to the existing board road or within the existing dike system. Only minor amounts of sediment generated by repairing these structures should be deposited outside the dike; most of the sediment will be contained 
within the dike. Normal operating conditions will not result in any impact on the surrounding wetlands or the floodplain. Minor spills will be contained within the dike system and will be promptly collected and disposed of. A well blowout would result in the discharge of geopressure fluid (i.e., brine) to the adjacent wetlands (see section 1.3 .1 .5 "Accidents" and "Chapter 5 - Accidents"). This type of accidental discharge would severely affect the adjacent wetlands.

The 100-year floodplain is a storm surge resulting from the landward migration of a hurricane. As such, the occurrence of the 100-year flood is predictable in the short-term and, therefore, sufficient lead time is avaliable to secure the site. Any potential hazardous or toxic materials will be securely stored or removed from the site, all equipment will be secured, and personnel will be evacuated as necessary. In addition, the hurricane season is fairly predictable, allowing project activities to be scheduled to avoid potential problems associated with these storms. This lead time is sufficient to diminish the potential risk to lives and property.

3.5 Unavoidable Direct and Indirect Impacts

1) Small amounts of brine, drilling muds and hydrocarbons will be spilled during normal drilling and maintenance operations. However, the impacts will be limited in areal extent and depth and will not affect the fresh groundwater resources of the Chicot aquifer. 
2) During the exploration phase, air pollutants would be emitted by vehicles, drill rigs and construction equipment. However, these emissions are expected to be minor, short-term emissions, and would be readily dispersed. The accumulated level of impacts from drilling and maintenance is negligible.

3) There is potential for noise impact from the proposed action in the study area. However, because of the rural character of the study area, the impact will not affect a large number of people.

4) Only minimal wildlife disturbance will accompany access road preparation since the existing road will be used.

5) Turbidity generated during levee upgrading may temporarily lower local aquatic productivity and water quality.

6) Toxic materials stored in the ring levee may be inadvertently incorporated into the local food chain.

7) Noise and activity during drilling and maintenance may temporarily lower hunter success.

8) Powerline extension and pumping water into the ring levee will cause only a temporary, slight disturbance to flora and fauna.

9) In all probability, some brine will be lost to the surface and the soil, but the impact will be local and will not affect groundwater resources.

10) Gaseous releases, noise, and increased traffic (terrestrial), either directly or indirectly generated during testing and operation of a geopressured well, may cause adverse biological impacts to the area around the well site. 
11) Well testing will result in the direct release of steam and a variety of other gases and particulates. The short duration of these emissions makes it unlikely that the air quality will be significantly affected outside of the immediate area of the well.

The impact of flaring the gases from a single plume is expected to be small. The impact of the cooling device, if required, is expected to be negligible due to its small size. (However, it may cause a "steam fog" during freezing temperatures in winter, but the frequency of occurrence is likely to be only 13 days per year in the study area.)

12) Some noise impact is expected from the operation of the flow-testing and operation of the proposed action. Such noise emissions will not affect a large number of people because of the rural character of the study area.

13) Gaseous effluents may be directly harmful to flora and fauna and may indirectly cause acidification of local waters which would in turn solubilize trace heavy metals present. This would most likely occur inside the ring levee.

14) Noise, activity and vehicular exhaust may temporarily lower hunter success and local aquatic productivity.

15) If storm surge overtops the levee, contaminants from the drilling operation could pollute adjacent wetlands. 
Collins, A.G.

1975 Geochemistry of oilfield waters, development in petroleum. science. Elsevier Scientific Publishing Co., New York.

Craig, N., and J.W. Day

1976 Barataria Basin: eutrophication case history. Center for Wetland Resources, Louisiana State University.

Department of Energy (DOE)

1980 Geothermal energy geopressure subprogram sweet Lake No. I, Comeron Parish. United States Department of Energy.

Department of Interior (DOI)

1978 Impact prediction manual for the geothermal development. zepartment of Interior, FWS/OBS-78/77.

Energy Research and Development Administration (ERDA)

1977 Draft environmental impact assessment for CUI venture, application for geothermal loan guaranty (South Brawley Project). Geothermal Loan Guaranty Program, San Francisco Operation Office.

1976 An environmental assessment of proposed geothermal well testing in the Tigre Lagoon oil field, Vermilion Parish, Louisiana. Energy Research and Development Administration.

1977 Environmental assessment of the geopressure subprogrom of the Division of Geothermal Energy. July. EIA/GE/77-3.

Gustavson, T.C., M.M. McGraw, M.Tandy, F. Parker, and D.E. Wohlschlag

1978 Ecological implications of geopressured-geothermal energy development Texas-Louisiana Gulf coast region. USFWS, Biological Services Program, FWS/OBS-78/60.

Kharaka, Y. K., E. Callender, and R. H. Wallace

1977 Geochemistry of geopressured-geothermal waters from the Frio clay in the Gulf coast region of Texas. Geology. Vol. 5, pp. 241-244, April 1977.

Kharaka, Y. R., E. Collender, J. C. Chemerys, and M. S. Lico

1979 Potential problems arising from the disposal of spent geopressured-geothermal water's from coastal Texas and Louisiana. Given at Marine Technology Society Annual Meeting, New Orleans, Louisiana, October, 1979.

Oilfield Products Group Environmental Engineering 1977 Environmental information summary, Magcobar Products. Dresser Industries, Safety and Environmental Technical Bulletin 6. 


\section{REFERENCES (continued)}

Radian Corporation

1979 Evaluation of community noise impacts from a geothermal-geopressure driliing operation. In Environmental baseline monitoring in the area of general crude oil, DOE Pleasant Bayou number 1 - a geopressured-geothermal test well, by T.C. Gustavson. Bureau of Economic Geology, the University of Texas at Austin, Annual Report Vol IV.

Treshow, $M$.

1970 Enviroment and plant response. McGraw-Hill Book Co., New York.

U.S. Department of Energy

1980 Environmental assessment, geothermal energy geopressure subprogram, DOE Sweet Lake No. I, Comeron Parish, Louisiana. February. DOE/EA-0065. Assistant Secretary for Resource Applications. Washington, D.C.

U. S. Department of Interior (USDI)

1975 Final environmental statement for geothermal leasing program. U.S. Department of Interior.

Wallace, W.E.

1962 Water production from abnormally pressured gas reservoirs in south Louisiana. Paper from the Gulf Coast Association of Geological Society Transâctions 12:187-193.

Weres 0., K. Tsao, and B. Wood

1977

Resource, technology and environment at the geysers. Lowrence Berkeley Laboratory, Energy and Eunivroment Division, University of Califformia at Berkley LBL-5231. 
Blank

$$
3-26
$$




\subsection{Geology}

Unless the test we11 blows out and craters, or flows out of control for a long time (months or years), there will be no long-term environmental effects. Geopressured zone reservoirs combonly show rapid fluid pressure recovery to conditions very close to initial reservoir pressure, following long periods of production at very large flow rates (Wallace, 1962). The target reservoir in the Gladys McCall well site should return to approximately its initial conditions after testing is concluded; no subsidence or fault activation is expected.

Beneficial effects on the physical setting, in terms of geology or subsurface hydrology, might include the creation of a relatively shallow reservoir of low-grade heat, formed by the waste-water disposal operation. This would be inconsequential if the volumes produced and disposed are small.

\subsection{Physiography and Soils}

During normal operations, cumulative and long-term adverse impacts will be limited to so: 1 contamination by small amounts of drilling fluids, fuels, lubricants and brine. Soil contamination by such fluids can have longterm effects, but the volume of brine leakage should be small and the impact would be limited to the production well, pipelines and disposal well sites. Normal system maintenance should insure that brine leaks are minimal and corrected when they are detected. 
No known cumulative and beneficial impacts on the physiography and soils of the study area will result from the proposed action. Benefits will result from any mitigation programs around the proposed action in the form of accummulated knowledge on subsidence and fault activation.

\subsection{Groundwater}

The Chicot aquifer and the limited groundwater resources of the chenier to the north should not be adversely impacted.

\subsection{Surface Water}

Probable cumulative and long-term adverse environmental effects on surface water are as follows:

1) Change of water circulation patterns and water levels due to site preparation activities.

2) Possible water quality alteration from chemical and thermal pollution and from runoff containing lubricants and other toxins introduced into this environment by development of the well.

3) Possible consumption of local water resources for developmental, cleaning or operation purposes:

Although it is not presently planned, if the constituency of the produced fluid allows, the produced waters could be used to supplement or enhance the extensively developed wildlife management practices conducted in the area. 


\subsection{Wildlife and Vegetation}

Chronic low level discharges of drilling muds, hydrocarbons, metals and acids from the well site may have a cumulative long-term effect on biological productivity in the vicinity of the well.

Habitat changes at the well site are likely to occur. Terrestrial vegetation will occur on the ring levee, while a bluegreen algae mat may develop within the levee borders. In any case, more tolerant communities are likely to develop in the impacted areas.

The upgraded ring levee will provide additional terrestrial wildlife habitat including potential nesting sites for resident bird species. However, the noise level at the site may preclude wildiffe utilization during the three-year period of the well test.

\subsection{Land Use}

There is no land use change as a result of the proposed action.

\subsection{Socio-economic}

No probable cumulative and long-term effects upon the socio-economic characteristics of the area are expected from the proposed construction and testing operations.

\subsection{Air Quality}

There are no known long-term or cumulative impacts on the air quality of the study area. 
4.9 Recreational, Archaeological and Historical Sites

No long-term adverse effects on cultural resources are anticipated, since there are no known cultural resources in the area of the proposed action. Since the nearest recreational area is approximately $3.7 \mathrm{~km}$ $(2.3 \mathrm{mi})$ away from the proposed action, no probable cumulative and long-term impacts are expected to occur upon designated recreational facilities.

\subsection{Federal, State, Regional and Local Land Use Programs}

There are no cumulative or long-term impacts associated with the proposed action that would affect any know Federal, state, regional and local land use programs.

No beneficial cumulative impacts are expected upon Federal, state, regional and local land use programs, other than that local governments, realizing the area's potential for geopressured resources, may develop and adopt rules and guidelines concerning these resources.

\subsection{Noise}

No long-term noise effects are expected. 
CHAPTER FIVE - ACCIDENTS

As of the preparation of this document, there are no known detailed studies of well blowouts or other accidents associated with geothermalgeopressured wells in the Gulf coast area. However, EPA conducted studies on two well blowouts in the wetlands of south Louisiana which indicate the areal extent of contamination from such accidents. These two well accident studies were on the Edna-Delcambre well in Vermilion Parish, Louisiana (ERDA, 1976) and the McCormick Oil and Gas Well $1.6 \mathrm{~km}$ ( $1 \mathrm{mi}$ ) south of Intracoastal City, Louisiana (Castle, 1975). The Edna-Delcambre well blew fluid into the air approximately $30 \mathrm{~m}(100 \mathrm{ft})$. As a result of winds, brine fallout occurred at a maximum distance of $610 \mathrm{~m}(2000 \mathrm{ft})$ from the well site. At the McCormick 0 il and Gas Well, maximum drift of fluid discharge was approximately $1830 \mathrm{~m}(6000 \mathrm{ft})$. Major contamination extended out $1525 \mathrm{~m}$ ( $5000 \mathrm{ft}$ ) and covered an area of 269 ha (665 ac) (Castle, 1975). The type of fluid and amount of discharge will depend on the character of individual wells. Some indications of what may be found at the Gladys McCail well site are available from other studies (Hankins and Karkalits, 1978; Wilson et al., 1977) (Tables 5-1, 5-2,5-3, and 5-4). These estimates of components and concentrations were used to estimate the potential adverse impacts resulting from the proposed action.

OSHA guidelines protect worker health and welfare at the site of the proposed action. These programs are well-defined and are the 
Table 5-1. Summary of Water Analyses from Edna Delcambre We11.

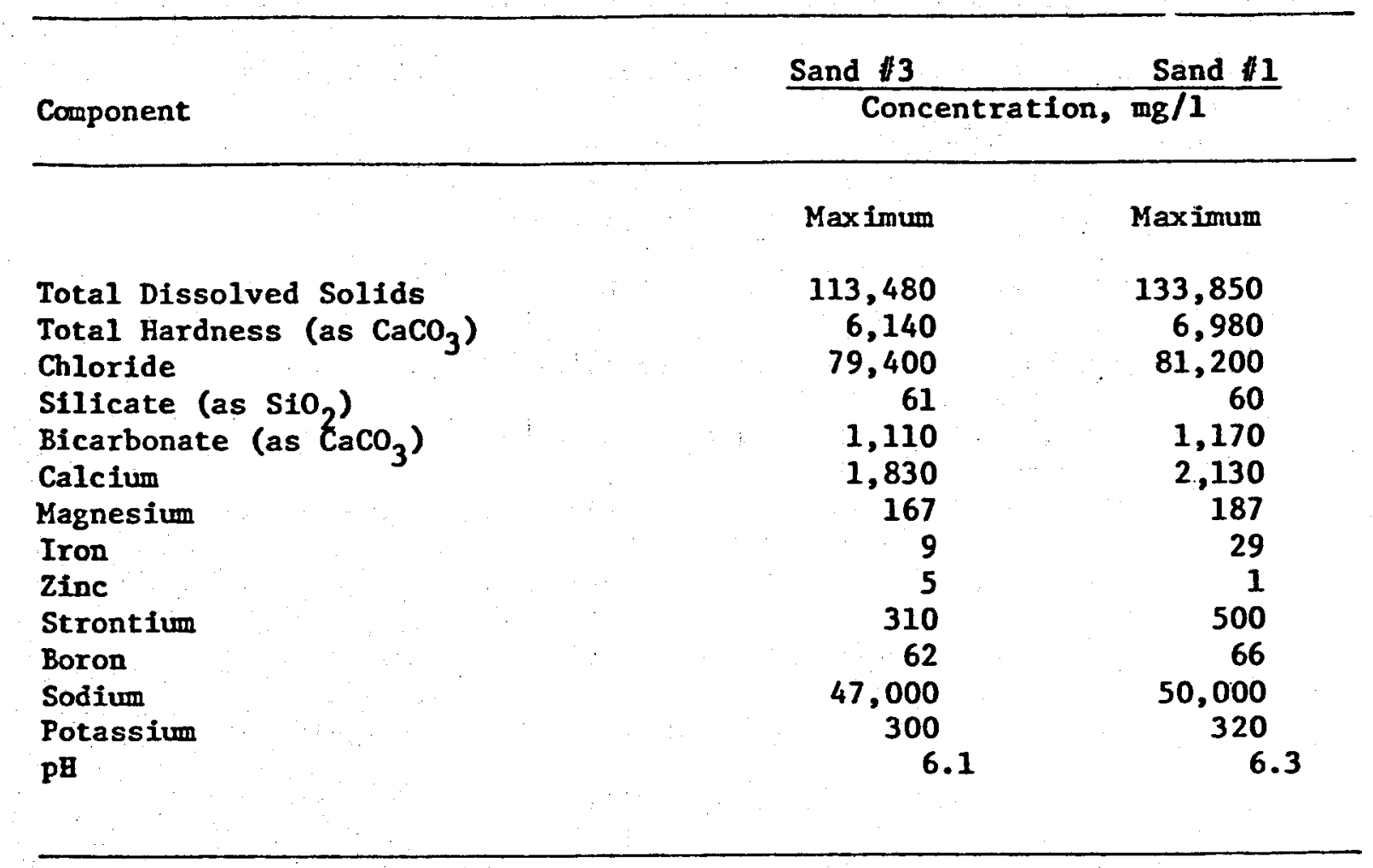

Source: Hankins and Karkalits, 1978

Table 5-2. Range of Concentrations Reported for Louisiana Geopressured Waters.

\begin{tabular}{|c|c|c|c|c|}
\hline \multirow[b]{2}{*}{ Component } & & \multicolumn{2}{|c|}{ Concentration, mg/l } & Number of \\
\hline & & Minimum & Maximum & Analyses Reported \\
\hline Total Dissolved Solids & & 200 & 345,000 & 64 \\
\hline Sodium & & 10 & 103,000 & 65 \\
\hline Potassium & & 50 & 1,100 & 45 \\
\hline Calcium & & 8 & 33,000 & 65 \\
\hline Magnesium & & 0 & 24,000 & 63 \\
\hline Chloride & & 10 & 201,000 & 66 \\
\hline Sulfate & & 0 & 407 & 61 \\
\hline Bicarbonate & & $\mathbf{0}$ & 2,500 & 65 \\
\hline Lithium & & 2 & 18 & 46 \\
\hline Strontium & & 3 & 265 & 10 \\
\hline Barium & & 4 & 1,000 & 34 \\
\hline Bromine & & 14 & 213 & 44 \\
\hline Iodine & & 5 & 74 & 45 \\
\hline Boron & & 18 & 67 & 38 \\
\hline
\end{tabular}


Table 5-3. Typical Gas Analysis from Delcambre Test Well.

Mole \%

Components

Sand $\$ 3$

Sand 1

\begin{tabular}{|c|c|c|}
\hline $\mathrm{CO}_{2}$ & 1.08 & 2.03 \\
\hline $\mathrm{N}_{2}$ & 0.29 & 0.13 \\
\hline $\mathrm{CH}_{4}$ & 92.78 & 95.36 \\
\hline & 3.47 & 1.73 \\
\hline $\mathrm{C}_{3} \mathrm{H}_{8}$ & 1.12 & 0.37 \\
\hline $1-C_{4} H_{10}$ & 0.42 & 0.09 \\
\hline$n-C_{4} H_{10}$ & 0.32 & 0.09 \\
\hline$i-C_{5}{ }^{H} 12$ & 0.14 & 0.05 \\
\hline${ }_{11}-C_{5} \mathrm{R}_{12}$ & 0.09 & 0.04 \\
\hline$c_{6}^{\prime} s$ & 0.09 & 0.02 \\
\hline C plus & 0.20 & 0.09 \\
\hline
\end{tabular}

Source: Karkalits and Hankins, 1978

Table 5-4. Chemical Composition of Geopressured Waters in South Central Louisiana.

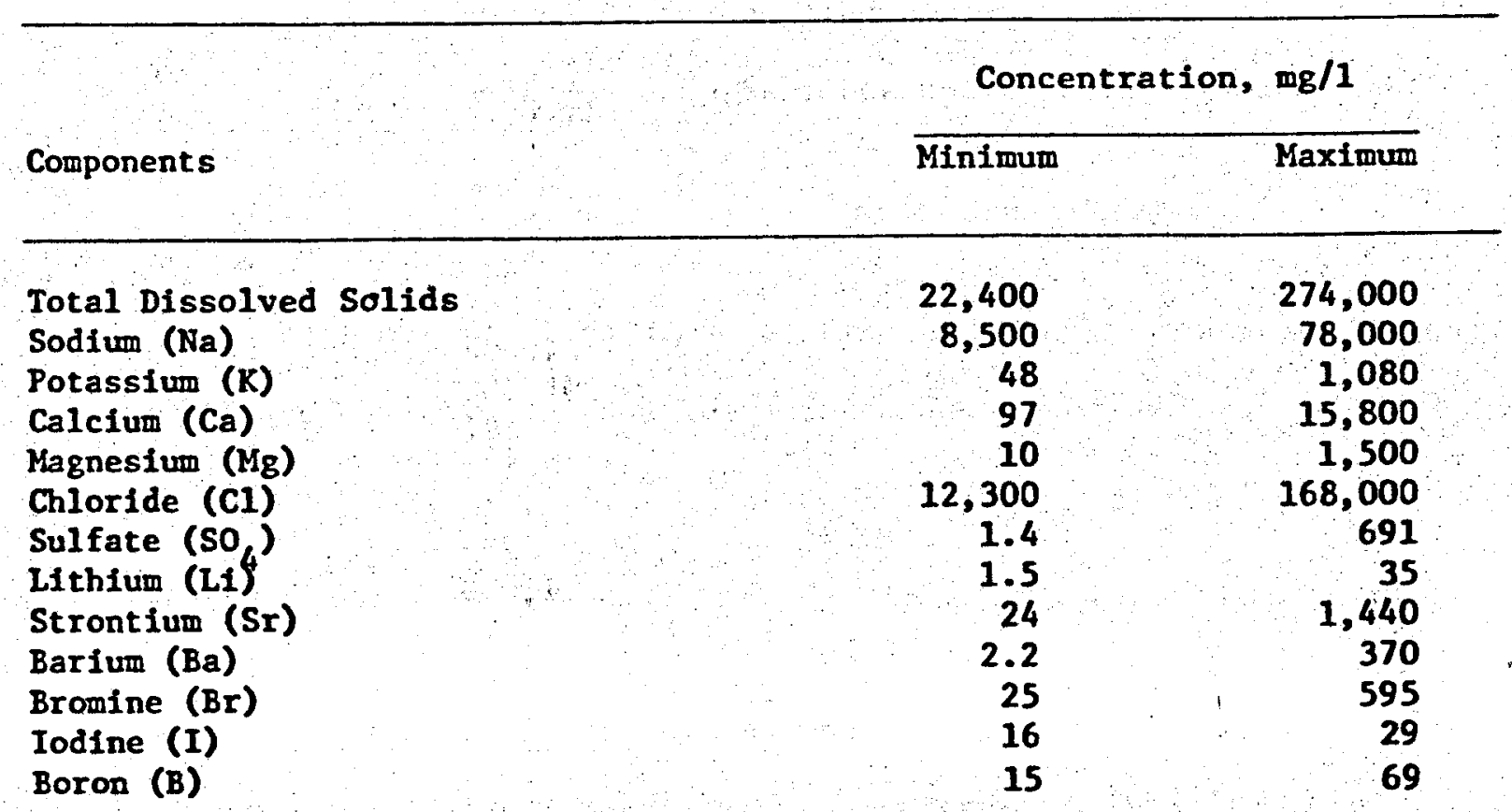

Source: Rharaka, Brown and Carothers, 1978 
responsibility of the driller. The Department of Energy is directly concerned with reducing the potential of an accident which results in the uncontrolled release of heated brines and other fluids and gases into the environment. In order to reduce the possibility of such an accident, blowout preventers will be installed, high pressure pipes and valves will be used, and casings will be cemented as required by good operating practice and in compliance with Federal and state laws. Annular space of each well will be cemented completely from the formation to the surface to provide greater stability to ensure sealing of aquifers. A spill prevention control and countermeasure plan will be developed for the project. Weighted mud and high pressure mud pumps capable of injecting mud into the well to control pressures will be used during the proposed action.

\subsection{Accidents During Site Preparation and Access Construction}

\subsubsection{Geology}

Negligible effects on geologic conditions may be expected as a consequence of site preparation and road construction.

\subsubsection{Physiography and Soils}

Accidents may cause spillage of oils or other toxic fluids into the study area. The extent and severity of such an occurrence will depend on the type of spillage.

\subsubsection{Groundwater}

Contamination of near surface groundwater may result from the spillage of oils or other toxins. Fresh groundwater resources of the Chicot 
aquifer and of the cheniers should not be adversely impacted.

\subsubsection{Surface Water}

Accidents during road and site preparation are those common to any construction or industrial development requiring use of heavy machinery, vehicles and lubricants or other toxic products. Leaking or overturned lubricant tanks could introduce pollutants into surface drainage. Fire and explosion could have the same effect. Toxins in materials being brought to the site and stored and used there represent a potential impact to surface waters if they are, by accidental leak or collision, allowed to mix with the surface waters.

In the particular setting of the Gladys McCa1l well site, construction accidents would have minimal effect since the well site is within an existing ring levee and is accessed by an existing plank road. However, accidents could still close drainage ditches or breach levees or other retaining structures. The effect would be to alter surface flow patterns, allowing otherwise segregated water sources to mix.

\subsubsection{Wildife and Vegetation}

Spills and fires will be the most probable accidents during site preparation and road resurfacing. Accidental spll1s of lubricants, fuels, drilling muds, or chemicals would probably kill exposed plants. Since most of the area is aquatic, such a spill 
could be washed into surrounding areas to damage the habitat and perhaps be incorporated into higher members of the food chain.

Extent of the damage would depend on cleanup procedures. The area is within a system of levees which would eventually contain even a major spill. A spill within the ring levee at the well site would be easily contained. Surfactants will not be used to clean up spill since they are harmful to vegetation (Cowell, 1969). Burning might remove a major portion of the hydrocarbons, and it would destroy existing vegetation; reestablishment of perennials will not be retarded. Since most spills associated with site preparation will probably be small, direct pick-up might be the safest answer to the problem.

Fires will only affect terrestrial vegetation which should recover quickly on roadsides and on the ring levee. A fire would not spread far into the wet marsh through the standing water since this area is impounded.

\subsubsection{Land Use}

In case of an accident during site preparation or road upgrading, the impounded wetland areas adjacent to the existing well site could be affected temporarily or permanently, depending on the nature or extent of the accident, but no land uses other than the existing well site would be impacted by an accident. 


\subsubsection{Socio-economic}

In the case of an accident, the only adverse impact expected would be to the individual or Individuals involved. No general impact upon the socio-economic character of the study area is envisioned to occur from such an accident.

\subsubsection{Air Quality}

During site preparation and access construction, the impacts on air quality will result from dust, exhaust emissions from construction machinery and non-condensable gases released from geopressured fluids during pre-construction flow-testing. These releases are expected to be minor and short-term, and should be readily dispersed because about $62 \%$ of the time the atmospheric stability classes are in $D$ and E (see Section 2.6.2). However, accidents such as a blowout may occur due to pre-construction flow-testing. For a discussion of blow-out with respect to air quality, see Section 5.2.8.

\subsubsection{Recreational, Archaeological and Historical Sites}

Accidents during site and road preparation will have no adverse impact on cultural resources, since there are no known cultural resources in the area of the proposed action.

No impacts to designated recreational sites from accidents during site preparation are expected to occur. An accident may affect the surrounding area which is used for hunting and fishing. 
5.1.10 Federal, State, Regional and Local Land Use Programs

There are no foreseen adverse short- or long-term impacts which could affect any existing or known proposed Federal, state, regional, or local land use programs.

\subsubsection{Noise}

With the exception of explosions, noise caused by accidents during site and road preparation should go unnoticed by the closest residents. The effects of an explosion will vary directly with the distance between the closest receptor and the accident location. The possibility of any explosion occuring during this phase of the operation is exceedingly remote.

\subsection{Accidents During Drilling and Operation}

\subsubsection{Geology}

Accidents that mignt have serious impacts on the geologic conditions and subsurface hydrology are (1) blowout with cratering, or (2) uncontrolled flow at very high rates. Whenever wells are drilled into the geopressure zone, there is the danger of blowout (Stuart, 1970). When this occurs, the producing formation may be seriously damaged by erosion, collapse, and structural deformation in the vicinity of the well bore, with similar and even more widespread effects in overlying formations. With destruction of well casing by explosive movement of water and sand upward, 
cratering begins. Blowout craters more than $610 \mathrm{~m}(2000 \mathrm{ft})$ in diameter, with bolling hot water and mud discharging steam, have been formed in South Loulsiana in several oll drilling accidents where wells penetrated the geopressure zone. Craters have boiled for months before killing themselves, or being brought under control by wells drilled nearby to kill them.

Accidents during drilling can permanently damage target reservoirs and all prospective overlying reservoirs, by physical disruption as well as long-lasting hydrologic effects. However, the geologic damage is likely to be local in extent. The hydrologic and hydrodynamic effects could be widespread and long-lasting, especially if dissolved gas is released in vapor phase in several overlying aquifers, as appears to have occurred as a consequence of the Tigre Lagoon blowout in 1969. Cross flow of saline waters and the contamination of shallow freshwater aquifers as a result of blowout are likely to be local in effect.

\subsubsection{Physiography and Soils}

Contamination of soils may result from a blowout of the well during the drilling phase of the proposed action.

\subsubsection{Groundwater}

Significant threats to the quality of local groundwater could arise as a result of accidents which would cause deep formation brines to enter freshwater aquifers during drilling and operation of the geopressure well and the associated brine disposal wells. Fresh groundwater could become 
permanently contaminated with brine high in $\mathrm{NaCl}$ and other constituents Buch as boron (Gustavson and Kreltler, 1976). Possible groundwater contamination mechanisms include:

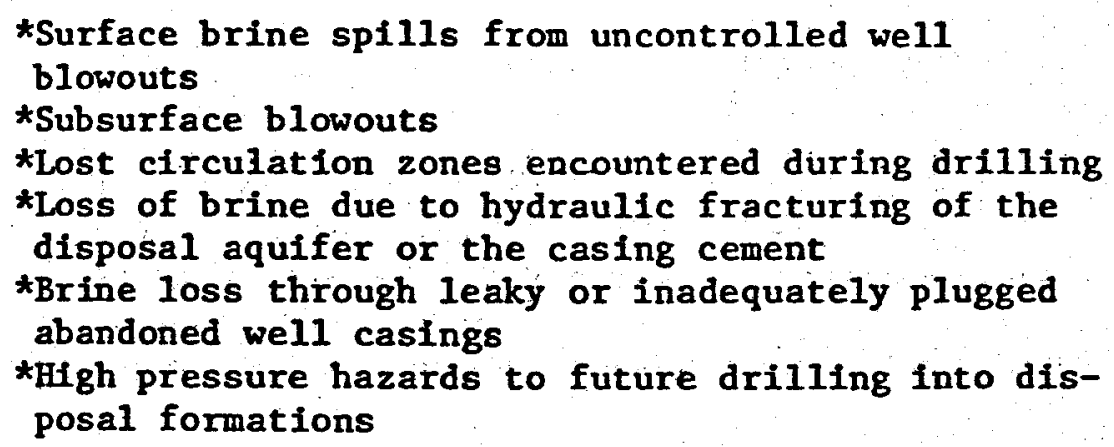

The former three mechanisms - surface blowouts, subsurface blowouts and lost circulation - could occur with both production and brine disposal wells. However, because production wells will penetrate geopressured reservoirs and brine injection wells will be completed in normally pressured sands within a few thousand meters of the surface, blowout hazards should be limited to production wells. The latter three mechanisms hydraulic fracturing, brine loss through abandoned wells and pressure build-up in disposal sands - are potential problems limited to the brine disposal well operations. Of all the hazards, the most immediate is a blowout of the deep production well.

In normal drilling operations the weight of the mud column in the hole is higher than the encountered formation fluid pressures. Hence, fluids do not flow from the formation into the we1l. If the weight of the mud column is less than formation pressure, an uncontrolled vertical flow of formation fluid can result in a blowout. 
Drflling Into deep, geopressured reservolrs requires all reasonable preventive measures be taken to maintain control of the well. Operational blowout preventers are required by the rules and regulations of the Louisiana office of Conservation. Drilling mud programs can take advantage of formation pressure data obtained from wells already drilled into the geopressured resource to assure that adequate mud weight is maintained. If equipment malfunctions or other accidents result in a well blowout, drilling muds and formation fluids spilled on the surface would contaminate the soils and shallow groundwater. The extent of contamination is dependent on the volume of fluid produced and the length of time the well is out of contro1. Limited volumes of fluid can be impounded at the well site to control the area of Impact. High flow rates could result in contamination over a large area. Groundwater resources in the deeper Chicot aquifer are not likely to be affected by a well blowout at the surface.

Blowouts can occur totally below the surface if fluid from one formation (not necessarily geopressured) is lost to another formation of lower fluid pressure. In the worst case, a brine flow could be established from a deep saline aquifer into the fresh groundwater aquifer around the well bore. Such an occurrence should be prevented by the required surface casing and cementing program which is designed to seal off the freshwater resources. Should a subsurface blowout occur, a large volume of brine could be introduced into the Chicot aquifer and local domestic wells may be adversely affected. If the impact of this contamination was determined to be significant, the "slug" of contaminating brine could be partially removed from the aquifer by pumping specially designed wells. The exact engineering solution will depend on the specific conditions at the site. 
During drilling, drilling muds and other flulds can enter the fresh groundwater aquifer in zones of "lost circulation" where the aquifer is highly permeable (gravel zones) and the pressure exerted by the column of drilling mud is greater than the fluid pressure in the aquifer. Lost circulation can usually be corrected by varying mud weight and viscosity, or ultimately by casing-off the problem zone.

Aquifer contamination from this source is expected to be insignificant because the amount of fluid lost before circulation is reestablished will be small (a few barrels perhaps), and the fluid will likely be freshwaterbased mud.

Brine must be injected into saline sands which are under hydrostatic pressure (i.e., formation pressure is equal to the pressure produced by a column of water of height equal to the depth of the aquifer concerned, about $0.45 \mathrm{psi} / \mathrm{ft}$ of depth). If injection pressure approaches or exceeds geostatic pressure (the weight of the overburden, about 1 pound per foot of depth), the area around the well bore and the formation can be fractured. Vertical flow paths could be created and brine could be forced into shallow freshwater aquifers.

Hydraulic fracturing is unlikely in normal brine injection operations because injection pressures are maintained well below fracture pressures (about $0.75 \mathrm{psi} / \mathrm{ft}$ of depth is generally considered to be the maximum safe injection pressure). (Fracture gradients of 0.8 to $0.85 \mathrm{psi} / \mathrm{ft}$ have been reported for injection aquifers on the Gulf coast [Knutson and Boardman, 1978].) Aquifers of adequate volume for safe containment of the required volume of brine disposal are expected to exist (Table 1-1). 
Problems associated with excessive pressures developed during brine disposal are unlikely in view of experience in brine disposal operations in the region and other areas of coastal Louisiana. The Louisiana Department of Natural Resources (1978) reported that a total of 11.87 million barrels of brine had been injected into saline aquifers at two nearby fields (Crab Lake and Little Pecan Lake) by 1976. The Gladys McCall flow-test well will produce a maximum volume of approximately 50 million barrels. The back pressures will be regulated to assure acceptance of the fluids by the receiving aquifers.

Brine injection will undoubtedly increase the formation pressure in the receiving formation. Although the increase is expected to be localized around the well and to dissipate when injection is stopped, it is possible that abandoned wells cased through the same disposal reservoir have leaky, inadequately plugged casings which provide vertical flow paths for release of injection pressure build-up. Injected brine or native formation brine could be displaced through shallower casing leaks into saline sands, freshwater aquifers or even to the surface. Subsurface leaks are unlikely to be detected. Abandonment records of all wells near the planned disposal wells will be checked to insure an adequate plug exists below the base of fresh groundwater.

If brine disposal aquifers are totally confined, they will permanently retain the pressure increase produced during brine injection. It is possible the pressure could be higher than that anticipated in future drilling ventures in the area. Future operators must be aware of any unnatural formation pressures created in previously normally pressured formations so that back-flows and blowouts can be avoided. 
creation of permanently pressured disposal reservoirs is unlikely. Such a possibility can be avolded by monitoring the disposal wells to assure that the aquifer volume is sufficient to receive the brine without excessive pressure increase.

\subsubsection{Surface Water}

Accidental discharge of geopressure fluids to the surface constitutes the major threat to surface waters during drilling and testing of the well. High temperature and pressure of the geppressured resource increase the possibility of accidents during this phase of the proposed action. Blowouts, thermal wellhead and casing cracks, scaling and clogging of injection wells, leaks, spills and human errors all could result in accidental venting of produced fluids to the surface where they could be introduced into surrounding surface waters by drainage, seepage or flooding.

Dorfman and Deller (1976) list these impacts from surface disposal, whether routine or accidental:

1) Contamination of shallow aquifers and soils from leaks or flooding;

2) destruction of non-salt-tolerant vegetation adjacent to water;

3) interruption of animal migration patterns;

4) disruption of food chain and ccological balance in estuarine waters; and

5) thermal pollution 
Produced geothermal fluids range in temperature from $150^{\circ} \mathrm{C}\left(302^{\circ} \mathrm{F}\right)$ to $260^{\circ} \mathrm{C}\left(500^{\circ} \mathrm{F}\right)$, while the highest recorded temperature in the Gulf coast region is $273^{\circ} \mathrm{C}\left(523^{\circ} \mathrm{F}\right)$ at a depth of $5859 \mathrm{~m}(19,225 \mathrm{ft})$ (Dorfman, 1976). Chemical composition of the produced fluids varies from formation to formation, but Sabadell and Axtmann (1975) report a high probability of environmental pollution by trace metals in geothermal fluids.

Table 5-5 1ists tolerance levels suggested by EPA (1976) for selected constituents in surface water. The range of relative hazard of constituents for which data are available can be evaluated by comparing suggested tolerance levels (Table 5-5) with levels of constituents found in Louisiana geopressured fluids (Table 5-6). The range of relative hazard is calculated by dividing the observed minimum and maximum concentrations by the appropriate suggested tolerance limit (Schieler, 1976). This gives a number which indicates how much, if any, a given constituent's concentration exceeds maximum allowable concentrations (Table 5-7).

On the basis of these avallable data, chloride, IDS, sodium and boron are constituents which appear to present the greatest potential hazard and thus the greatest potential adverse impacts to surface water quality. However, unknown hazards from toxic trace elements whose concentrations are unknown and for which no tolerance limits have been set may prove to be far more harardous to surface water quality.

All species of fish and other aquatic life must tolerate a range of dissolved solids concentrations in order to survive. Estuarine and marsh 
Table 5-5. Chemical Composition of Louistana Geopressured Waters* (Range of Concentrations in $\mathrm{mg} / \mathrm{l}$ ).

\begin{tabular}{|c|c|c|}
\hline \multirow[b]{2}{*}{ Component } & \multicolumn{2}{|c|}{ Concentration, $\mathrm{mg} / 1$} \\
\hline & Minimum & Maximum \\
\hline Barium & 2.2 & 4.1 \\
\hline Bicarbonate & 960 & 1,170 \\
\hline Boron & 56 & 65 \\
\hline Calcium & 1,630 & 2,130 \\
\hline Chloride & 66,800 & 81,200 \\
\hline Magnesium & 157 & 187 \\
\hline Potassium & 260 & 320 \\
\hline Sodium & 40,000 & 50,000 \\
\hline Strontium & 280 & 500 \\
\hline Sulfate & 134 & 214 \\
\hline Total Dissolved Solids & 113,180 & 133,850 \\
\hline
\end{tabular}

¿Edna Delcambre No. 1 Well, Vermilion Parish, Louisiana

Source: Hankins and Karkalits, 1978

Table 5-6. Range of Relative Hazard of Known Geopressure Fluid Constituents.

\begin{tabular}{lccc}
\hline Constituent & $\begin{array}{c}\text { Range of } \\
\text { Concentration }\end{array}$ & $\begin{array}{c}\text { Tolerance Level of } \\
\text { Domestic Supply (ppm) }\end{array}$ & $\begin{array}{c}\text { Range of } \\
\text { Relative hazard }\end{array}$ \\
\hline TDS & $113,180-133,850$ & 500 & $226-268$ \\
Chloride & $66,800-81,200$ & 250 & $267-325$ \\
Sulfate & $134-214$ & 250 & $0.5-0.9$ \\
Barium & $2.2-4.1$ & 1 & $2.2-4.1$ \\
Boron & $56-65$ & 0.750 & $75-87$ \\
Sodium & $40,000-50,000$ & 270 & $148-185$ \\
\hline
\end{tabular}


Table 5-7. EPA Suggested Water Qualtiy Criteria.

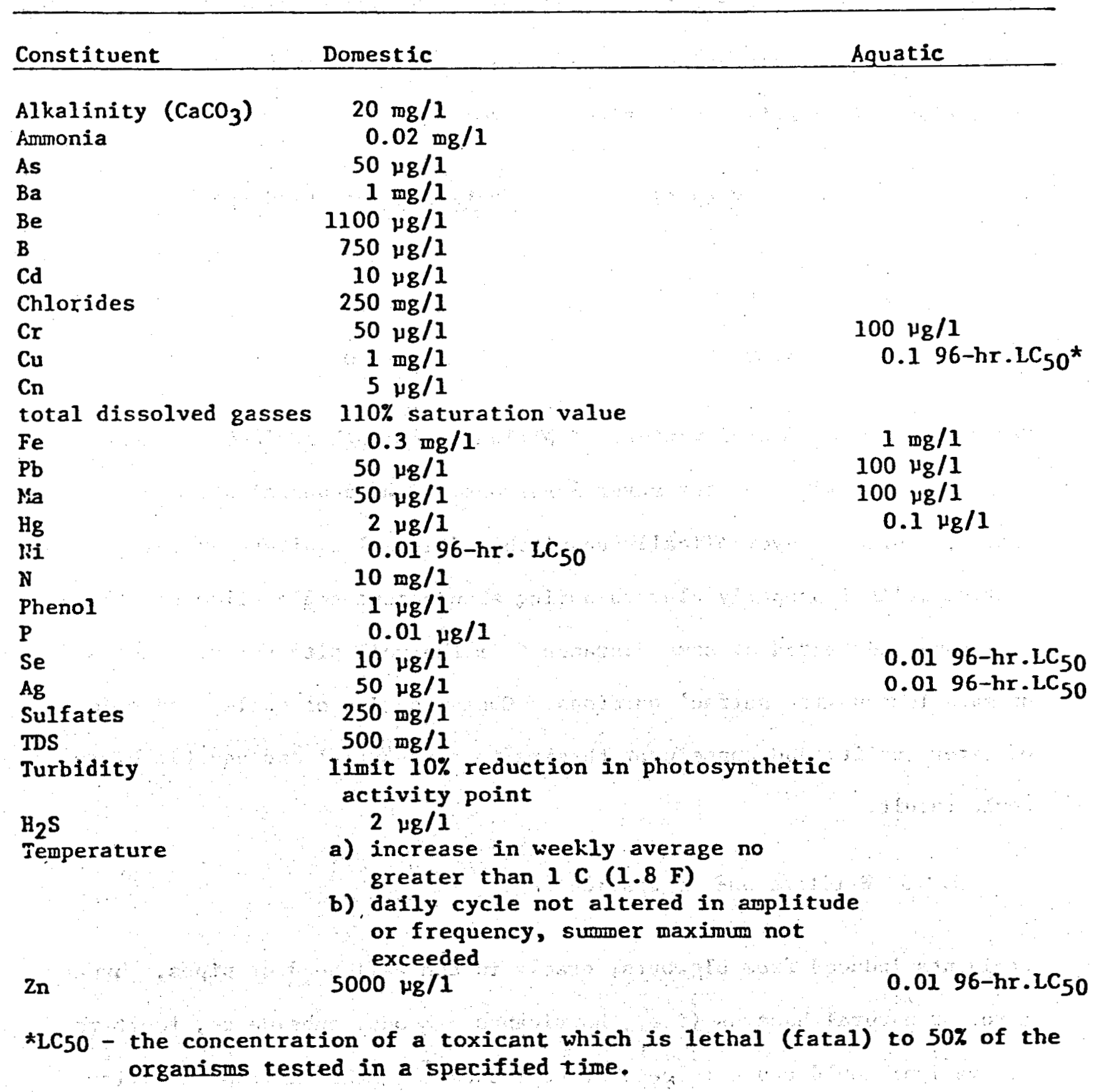

Source: EPA, 1976 
species tolerate changes from fresh to brackish to seawater. Any abrupt changes in these aspects of existing water quality resulting from accidental discharge of geopressured fluids into surface waters could eliminate species of animals and plants or eliminate desirable habitat. The following limits in salinity variation have been recommended to protect wildiife, vegetation and existing habitat (EPA, 1976):

$\begin{array}{cc}\text { Natural Salinity (ppt) } & \text { Varlation Permitted (ppt) } \\ 0.0-3.5 & 1.0 \\ 3.5-13.5 & 2.0 \\ 13.5-35.0 & 4.0\end{array}$

Undetected or accidental venting of effluents through surface or subsurface faults could occur for several reasons. Faulty installation of casing, choice of hydraulically unsuitable disposal aquifers or reinjection wells improperly plugged during abandonment could allow the fluids to escape undetected at some distance from the well site through faults or sand lenses with surface outcrops. Contamination of soils, reduction of water quality and consequent threats to terrestrial and aquatic biota could result.

\subsubsection{Wildife and Vegetation}

Accidents induced from blowouts, cracks in the well head or pipes, human error or natural hazards (i.e., hurricanes, floods, subsidence, fault reactivation) could cause release of toxicants into the environment. The range and seriousness of the resulting impacts are dependent on the type, composition, quantity and length of exposure of the biologically degrading 
material released and various environmental factors such as wind speed and direction, light conditions, temperature and atmospheric moisture.

of the possible accidents, a blowout will probably have the greatest impact on the surrounding vegetation and wildlife. The constituents of geopressured effluents and their concentration will determine their toxicity. Some of the expected constituents in geopressured brines are listed in Table 5-8. Comparison of concentrations in brine and acceptable standards are shown and those substances considered to be hazardous are marked with an " $\mathrm{X}$ ".

Sodium, potassium, calcium and magnesium are necessary nutrients for plants. All but calcium may be detrimental at their brine concentration, but will not be harmful once diluted by surrounding waters.

Chloride ion is the single most prevalent ion in brine. It can be detected by animals at low levels. Any increase in chloride or dissolved solids levels in the area must be compensated for by increased respiratory demands of flora and fauna. Sudden changes in ion ratios are more harmful than slow changes. Larvae and juveniles of a species find it hardest to adapt to changes. It is likely that dilution would mitigate this impact in the flooded marsh areas. Bottom communties and rooted vegetation would have the greatest disturbance. Clay fractions in the flooded soils with high exchange capacities would extend the persistence of the salinity problem. An elevation of salinity values over 39 ppt would kill Spartina patens, the most abundant marsh plant (Palmisano, 1970). 
Table 5-8. Constituents in Geopressured Brines of Environmental Concern (ppm).

Hazard Components Minimum $^{1}$ Maximum $^{1}$ Acceptable $^{\text {Standard }}$

(X)

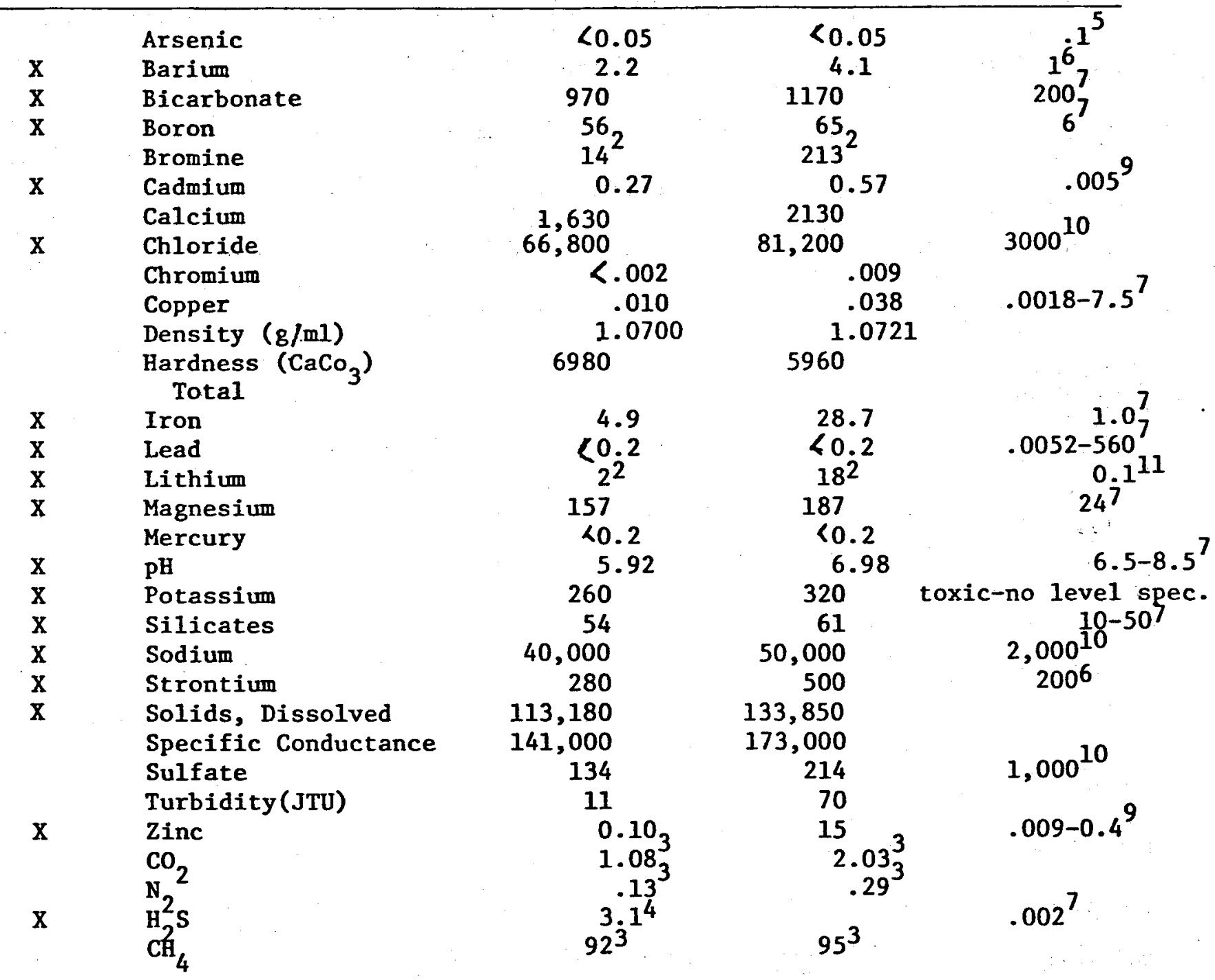

1 range of constituent when found by Hankins and Karkalits, 1978.

Wilson, et al, 1977.

Karkalits and Hankins, 1978.

4 CSGPC, 1970 .

6 Agricultural Use Criteria, EPA, 1978. Toxicity to crops at 5.

EPA, 1976, for domestic supply.

Gustavson, et al, 1978.

8 Thompson and rats, 1977.

9 EPA, 1976, for marine organisms, 004 for cladoceran fishes in soft water.

11 Gustavson, et al, 1978, limit of livestock watering.

Treshow, 1970. 
Increased hardness due to geopressured well effluents, while exceeding drinking water standards, may actually be beneficial since calcium and magnesium are necessary nutrients for plants and increased hardness raises the tolerance level of plants and animals to toxic heavy metals.

Heavy metals are commonly found in geopressured waters in significant concentrations (Wilson et al, 1977; Hankins and Karkalits, 1978; Mayer and Ho, 1977). Those particularly noted were zinc, boron, lithium, iron, barium, strontium, cadmium, lead and bromine.

Zinc may be a pollution problem in the brine effluent (Table 5-8). It was found to be toxic to Pacific oyster larvae at $0.2 \mathrm{ppm}$ even for a short period (Brereton et al, 1973) and to be harmful to fresh water fish fry, especially cladoceran fish in soft waters at levels of $.0004 \mathrm{ppm}$ (EPA, 1976).

The levels of zinc in soluble and exchangeable forms and its availability to marsh plant uptake will increase at a reduced $\mathrm{pH}$ and increased oxidation-reduction conditions (Gambre11 et al,, 1977a, 1977b). It would be most harmful at the low pH levels of brine. A secondary effect of zinc contamination is to cause a shortage of manganese uptake which lowers productivity (Treshow, 1970).

Boron levels are very high in geopressured brines. While some animals, especially minnows, are tolerant of high levels of boron, plants are sensitive and concentrate it in their leaves. Terrestrial plants exposed to boron or borate will show the greatest decline, showing inhibition of flowering, chlorosis and lowered plant production (Weres et al, 1977; Treshow, 
1970). These effects are mitigated under alkaline conditions (BIggar and F1reman, 1960) but will probably be associated with low pH brines.

Lithium, similarly, causes chlorosis, burning and impaired growth at the levels present in brine. Iron, barium, strontium, cadmium, lead and bromine may also be in excess of tolerable limits to fauna and terrestrial and aquatic flora. Their uptake will probably be greatest under reduced oxygen conditions such as those present in the impounded marsh surrounding the well site.

In sumary, heavy metal availability will depend on Eh, pH and constituents of the soil. The low $\mathrm{pH}$ in the brine could make initial availability high, while the low $\mathrm{pH}$ of soils in the marsh will allow complexing with clays that will cause these metals to persist for a long time.

$\mathrm{H}_{2} \mathrm{~S}$ gas has been measured near a geopressured site blowout at levels toxic or harmful to plants (Coastal States Gas Producing Co., 1970). This will probably be a very localized phenomenon.

Bicarbonates may cause some decline in terrestrial vegetation, but their indirect effect in the slightly acidic brine waters would be a release of $\mathrm{CO}_{2}$ which may have adverse effects on local aquatic fauna.

Silicates may cause turbidity at over $50 \mathrm{ppm}$. However, diatoms as noted in the area may reduce concentrations by using the silicate to form their frustules. 
Geopressure fluids may range in temperature up to $149^{\circ} \mathrm{C}\left(300^{\circ} \mathrm{F}\right)$. Brine discharge, with its high salt content, is toxic to most marsh vegetative communities. Although little information regarding lethal temperatures for terrestrial marsh plants is available, synergistic effects of temperature and salinity are probable (Gustavson et al., 1978). In addition to immediate death of vegetation in the near vicinity of the discharge, long-term effects may include a rather permanent change in the plant community toward more tolerant species and a decrease in plant diversity (Gustavson et a1.,1978).

Impacts on aquatic plants may also be severe. Temperature is evidently a primary factor in the seasonal distribution of Texas benthic marine algae (Edwards, 1969), and Thorhaug (1976) found temperature to be an important factor in the growth and survival of the seagrass community. Thus, discharge of heated brine waters could be deleterious to aquatic plants, such as wigeon grass (Ruppla maritima), at the site. Although temperature tolerances of marsh plant communitles are not known, it is reasonable to assume that such communities are not adapted to the thermal levels inherent in brine effluent, and serious mortalities would be likely.

In conclusion, there are many constituents in geopressured brines of biological concern. Toxicities are compounded by high salt concentrations, high temperatures, the abrupt nature of the change, duration of the spi11, and lack of circulation in the Impounded area (Anderson, 1973). South of the Impounded area, the spray from a blowout which could travel hundreds of meters could affect First Lake, Second Lake, and Hog Bayou, which eveutually drain into the Gulf of Mexico and connect to commercial fish nursery areas. 
Fauna surviving the spray w111 avoid areas where vegetation has been damaged. Fish kills may occur downstream in freeflowing areas. Contamination of cattle grazing land would take them out of production. Measures should be taken to discourage wildlife use of contaminated areas. Since the study area is brackish to intermediate marsh, the species present will be better adapted than a fresh marsh to a brine spill, and some tolerant species would probably survive a blowout. "The direction of winds at the time of a blowout could determine whether the spray drifted north and could be contained or drifted south to spread to Hog Bayou and estuarine areas.

It is possible that a blowout may occur while drilling through an oil or gas formation. In such a case oil or gas could fall on surrounding areas and may cause local damage and fires. The seriousness of such a spill would depend on the type of hydrocarbon, the dosage received, the physiography of the area, weather conditions at the time of the spill, the season of the year, previous exposure of the area to oil or other pollutants, and the type of cleanup treatment implemented (Straughan, 1972).

Damage to flora would be most severe when the leaves were coated with oil, which would probably result in death of the plant (Baker, 1971). Perennial plants with underground storage structures will be most likely to survive, and marsh flora in standing water will have a good chance to grow back from rhizomes. However, annuals on spoil banks and roadsides may not repopulate the area immediately after the spill. Continued oilings may increase mortality of plants and even animals, especially in aquatic systems (Cowell, 1971). Greatest damage to plants would occur during reproductive seasons; the time of year least damaging would be winter. 
Hydrocarbons may migrate down into the soll (Diet2, 1973) and persist there for years (Blumer and Sass, 1972; Whelan et a], 1976) since the oxygen required for their microbial degradation (Zobell, 1973) may be limited. An oil sheen on the sediment and leaf surfaces may reduce oxygen diffusion into the soil and lower vegetation productivity even though death does not occur (Gebhart, 1973). Oxygen deprivation and hydrocarbon toxicity may cause drastic reductions in aquatic animal life and may cause a shift in species composition toward tolerant members with less diversity.

The marsh comminicy can be expected to recover from a spill of hydrocarbons within a relatively short period of time either naturally or as a result of burning. Perennials would probably return within the next growing season, so Spartina patens marshes surrounding the test site would probably return even if leaves were damaged.

Annuals would be slower to repopulate the area and tree and shrub vegetation along levees or roadsides would be slow to reestablish. Since a blowout would probably be restricted to within a short distance from the we11, it could probably be contained within the impounded marsh area.

An oil slick resulting from a blowout could attract birds and would be most harmful during migrating perfods when bird populations in this area are very high (See Section 3.3.2). Oil ingested during preening could line the alfmentary tract and give sublethal to lethal doses of toxins to birds (Hartung and Hunt, 1966).

Dispersal of hydrocarbons will depend on the air and water teuperature and weather conditions, being least likely to disperse rapidly in the winter during calm wind and water conditions. 
Cracks in well heads or pipes and human error could also lead to pollutant discharge with similar effects as described above.

Natural hazards such as floods, hurricanes and leaks or breaks in the levee around the impounded marsh could cause washover of oils, drilling muds and metal shavings from the sump area into surrounding waters. If such a washover occurred after a brine or oil spill, pollutants could be spread to marshes to the east, west and south. It is likely that such events would involve rapid dilution of pollutants and only a minor damage would occur to the widespread area involved.

Fires might occur in the area of the well site, but would likely be quickly stopped by surrounding standing water. Some damage to spoil bank vegetation could occur. No major fires could start in the surrounding environment as a result of well drilling or operation.

\subsubsection{Land Use}

In case of an accident during drilling or a well blowout. hypersaline geopressured fluids could spill onto surrounding wetlands. The impact of such an accident will result in the destruction of the character of the area for the wetland habitat use. The duration of the change in land use will depend on the extent of the accident.

\subsubsection{Socio-economic}

There should be little, if any, impact on the socio-economic character of the study area because of an accident. The nearest development is 3.7 $\mathrm{km}(2.3 \mathrm{mi})$ from the proposed well site, and based on other accidents, fluids will not be carried this far. 


\subsubsection{Air Quality}

By standards of normal oil field operation, extraordinary precautions will be taken in the proposed action to prevent blowout of the test well. Yet the possibility of a blowout should be considered in view of the high pressures anticipated in the geopressured zone. Some documentation exists on blowout occurrences at various geothermal fields (ERDA, 1976).

Very little air quality tmpact data as a result of blowout are available in the literature. Some preliminary information may be inferred from the blowout of Edna Delcambre $\# 4$ gas well in the Tigre Lagoon area in Louisiana (ERDA, 1976). The blowout took place on July 13, 1971, and resulted from negligence during workover as rams were changed on the blowout preventers. Depth of the producing interval at the time of the blowout (July 13, 1971) was between 4081 to 4233 a $(13,380$ to $13,880 \mathrm{ft}$ ), with three to four thousand pounds flowing pressure.

The well caught fire 10 hours after blowout and the fire lasted for 10 days. Discharge of the highly saline ( $\$ 150 \mathrm{ppt}$ ) formation fluld continued for approximately three months until the well was made inactive. The well was finally plugged and abandoned on November 4,1971 , by pumping cement through the rellef well.

Since the emission rate of $\mathrm{H}_{2} \mathrm{~s}$ due to possible blowout from the proposed action in not known, one may calculate the impact on alr quality as the result of the oxidation from $\mathrm{H}_{2} \mathrm{~S}$ to $\mathrm{SO}_{2}$ from the experience gained by Edna Delcambre 4 well (ERDA, 1976). 
The computation of $\mathrm{SO}_{2}$ is based on the following assumptions:

A. Emission height is assumed to be about $31 \mathrm{~m}(100 \mathrm{ft})$. This Is based on data that during both the first and second blowout of Edna Delcambre 4 well, saline formation fluid was blown about $31 \mathrm{~m}(100 \mathrm{ft})$ vertically into the air.

B. Emission rate of $\mathrm{H}_{2} \mathrm{~S}$ is assumed to be about $6.8 \mathrm{Kg} / \mathrm{hr}$. This Is based on a Union 0il Co. well testing, which produced a total flow of $22,500 \mathrm{Kg} / \mathrm{hr}$., of which $3 \%$ was noncondensable gases. Ninety-nine percent of this was $\mathrm{CO}_{2}$. If the remaining percent is assumed to be entirely $\mathrm{H}_{2} \mathrm{~S}$, the total emissions of $\mathrm{H}_{2} \mathrm{~S}$ would equal $6.8 \mathrm{Kg} / \mathrm{hr}$.

C. Atmospheric stability is assumed to be F, the moderately stable condition commonly used as the air pollution computation for safety analysis.

D. Wind speed during stability $F$, which occurs about $14 \%$ per year in the study area, is $1.7 \mathrm{~m} / \mathrm{s}$. This is given in Section 2.6.2.

E. Blowout will result in the burning of the gas, which in turn will result in oxidation of the $\mathrm{H}_{2} \mathrm{~S}$ to $\mathrm{SO}_{2}$. Available data showed that 620 grams of $\mathrm{H}_{2} \mathrm{~S}$ would produce 1136 grams of $\mathrm{SO}_{2}$.

On the basis of the preceding information, the maximum concentration of $\mathrm{SO}_{2}$ may be computed from standard EPA techniques to be about $192 \mu \mathrm{gg} / \mathrm{m}^{3}$, which is below national ambient air quality standards of maximum 24 hour concentration of $365 \mu \mathrm{g} / \mathrm{m}^{3}$. The distance of this maximum concentration is expected to be about $1.6 \mathrm{~km}$ ( $1 \mathrm{mi}$ ) downwind from the blowout well. Although the concentration of $\mathrm{SO}_{2}$ is below air quality standards, because of the unusual odor of $\mathrm{H}_{2} \mathrm{~S}$, the area within a $3.2 \mathrm{~km}(2 \mathrm{mi}$ ) radius of the blowout well (such as campsites, if any) should be advised to evacuate. 
In sumary, the impacts of the proposed action on air quality are insignificant during construction and operation. However, should blowout occur, important pollutants will be $\mathrm{SO}_{2}$ and $\mathrm{H}_{2} \mathrm{~S}$. The maximum concentration of $\mathrm{SO}_{2}$ is estimated to be below national ambient air quality standards. At present there is no national ambient standard for $\mathrm{H}_{2} \mathrm{~S}$. However, because the "rotten $\mathrm{egg}$ " odor of $\mathrm{H}_{2} \mathrm{~S}$ can be detected at levels of $30 \mathrm{ppb}$, estimated $\mathrm{H}_{2} \mathrm{~S}$ concentrations of $80 \mathrm{ppb}$ as a result of a blowout will be a nuisance. The distance of this maximum concentration is expected to be about $1.6 \mathrm{~km}(1 \mathrm{mi})$ downwind from the blowout well. No adverse effect on air quality is anticipated even under conservative estimates during stable atmospheric conditions. The effect of inversion layer is also sma11, because the minimum height of that layer is about $390 \mathrm{~m}$ (1280 ft) above ground (Section 2.6.2).

\subsubsection{Recreational, Archaeological and Historical Sites}

No adverse effects are expected in any known designated recreational area; although hunting and fishing activities will be adversely affected by a blowout accident.

Accidental discharge of geopressured fluids will not affect any prehistoric cultural materials. No historic structures are located within the radius of a potential blowout. No adverse effect is expected from accidental release of toxic chemicals into the atmosphere.

\subsubsection{Federal, State, Regional and Local Land Use Programs}

There should be no adverse impact on any Federal, state, regional or local land use programs in the study area. 
$5-30$

5.2.11 Noise

The loudest noise level produced during drilling, again with the exception of an explosion, is the venting of the well in an unmuffle condition. These effects are discussed in Section 2.2 .11 , and are not expected to be harmful. An explosion during drilling should have no serious effects on receptors other than those at the drilling site. 
Anderson, R.D.

1973 Effects of petrolewn hydrocarbons on the physiology of the American oyster, crassostrea virginica Gmelin. Unpublished Ph.D. dissertation, Texas A \& $M$ University.

Baker, J.M.

1971 Seasonal effects of oll pollution on salt marsh vegetation. Oikos 22:106-110.

Biggar, J.W. and M. Fireman

1960 Boron absorption and release by solls. Soil science society American Proceedings $24: 115$.

Blumer, $M$. and J. Sass

1972 O11 pollution: persistence and degradation of spilled fuel 011. Science 176(4039):1120-1122.

Breretoo, A.R.

1973 Effect of zinc on growth and development of larvae of pacific oyster Crassostrea gigas. Marine Biology 19:96-101.

Castle, R.W.

1975 Observations of the Intracoastal City, Louislana gas well blowout and oil spill. URS Research Company.

Coastal States Gas Producing Company (CSGPC)

1970 Tigre Lagoon field sales to trunkline sampled at a meter run in the fleld, $\mathrm{H}_{2} \mathrm{~S}$ in grains/100 cu. ft. Coastal States Cas Producing Company.

Cowe11, E.B.

1969. The effect of oll pollution on saltmarsh communities in Pembrokeshire and Cornwall. Joumal of Applied Ecology 6:133-142.

1971 Some effects of oll pollution in Mllford Haven, $U . K$, edited by L. P. Haxby in Preventional and control of ofl spil1s: Proceedings of Symposizon American Petroleun Institute 429-436.

Dietz; D.N.

1973 Behavior of components from spilled oll on their way through the soil. Journal of Petroleun Technology September:1045-1046.

Dorfman, K.H.

1976 Water required to develop geothermal energy. American Water Works Association Journal 68(7):370-375. 
REFERENCES (continued)

Dorfman, M.H. and R.W. Deller

1976 Proceedings of the Second Geopressured Geothermal Energy

Conference, vol. 1:Stmmary and future projections 1-82.

Edwards, T.

1969 Field and cultural studies on the seasonal periodicity of growth and reproduction of selected Texas benthic marine algae. University of Texas. Contributions of Marine Sciences 14:59-114.

Energy Research and Development (ERDA)

1976 An environmental assessment of proposed geothermal well testing in the Tigre Lagoon Oil Field, Vermilion Parish, Louisiana. Energy Research and Development.

Environmental Protection Agency (EPA)

1976 Quality criteria for water. Environmental Protection Agency EPA-440/9-76-023.

1978 Pollution control guidance for geothermal energy development. Envirormental Protection Agency, Industrial Environmental Research Laboratory EPA-600/7-78-101.

Gambrell, R.P., R.A. Khalid, M.G. Verloo, and W.H. Patrick

1977a Transformations of heavy metals and plant nutrients in dredged sediments as affected by oxidation reduction potential and $\mathrm{pH}$. U.S. Army Engineer Waterways Experiment Station Contract Report D-77-4.

Gambrell, R.P., V.R. Collard, C.N. Reddy, and W.H. Patrick, Jr.

1977b Trace and toxic metal uptake by marsh plants as affected by oxidation-reduction conditions, $\mathrm{pH}$, and salinity. Dredged Material Research Program, Waterways Experiment Station, U.S. Army Corps of Engineers Contract No. DACW-39-73-C-0108).

Gebhart, J.I.

1973 The effects of varying levels of cmide oil on plants of the Louisiana coastal marshes. Unpublished master's thesis, Louisiana State University.

Gustavson, T.C. and C.W. Rreitler

1976 Environmental concerns arising from the production and disposal of geothermal waters. Bureau of Economic Geology, University of Texas, Geological Circular 76-7.

Gustavson, T.C., M.M. McGraw, M. Tandy, F. Parker and D.E. Wohlschlag 1978 Ecological implications of geopressured-geothermal energy development, Texas-Louisiana Gulf Coast region. USFWS Biological Services Progrom FWS/OBS-78/60, March. 


\section{REFERENCES (continued)}

Hankins, B.E. and O.C. Karkalits

1978 Geothermal test of the Edna Delcambre No. 1 well, Tigre Lagoon field, Vermilion Parish, Louisiana; analysis of water and dissolved natural gas. Division of Geothermal Energy, Department of Energy, Final Report.

Hartung, R. and G.S. Hunt

1966 Toxicity of some oils to waterfowl. Joumal of Wildlife Management 30:564-570.

Karkelits, D.C. and Häkins, B.E.

1978 Chemical analysis of gas dissolved in geothermal waters in a south Louisiana well. Proceedings, Third Geopressure-Geothemal Energy Conference, in press.

Kharaka, Y.K., P.M. Brown, and W.W. Carothers

1978 Chemistry of waters in the geopressured zone from coastal Louisiana -- Implications for the geothermal development. Transactions: Geothermal Resources Council 2:371-374.

Knutson, C.F. and C.R. Boardman

1978 An assessment of subsurface saltwater disposal experience on the Texas and Louisiana Gulf coast for application to Disposal of saltwater from geopressured-geothermal wells, USDOE. NVO-1531-2.

Louisiana Department of Natural Resources

1978 Sumary of Field Statistics and Drilling Operations. Louisiana Department of Natural Resources, Baton Rouge, Louisiana.

Mayer, J.F. and C.L. Ho

1977 Trace metals in selected aquatic environments of Loulsiana coastal zone. Coastal Studies Institute, Louisiana State University.

Palmisano, A.W.

1970 Plant community-soil relationship in Louisiana coastal marshes. Unpublished Ph.D. dissertation, Louisiana State University.

Sabade11, J.E., and R.C. Axtmann

1975 Heavy metal contamination from geothermal sources. Environmental Beazth Perspectives 12:1-7.

Schieler, L.

1976 Geothermal effluents, their toxicity and prioritization. Proceedings: First Workshop of Sampling Geothermal Effluents EPA-60019-76-011.

Straughan, D.

1972 Factors causing environmental changes after an oll spill. Journal of Petrolevon Technology March 250-254. 


\section{REFERENCES (continued)}

Stuart, C.A.

1970 Geopressures. Proceedings: Second Symposizm on Abnormal Subsurface Fluid Pressure 1-121.

Thompson, C.R. and G. Kats

1977 Effects of continuous $\mathrm{H}_{2} \mathrm{~S}$ fumigation of crop and forest plants. Manuscript submitted to Science and Technology.

Thorhaug, A.

1976 Ecological study of the effects of power plants on benthic macroplant microcosms in subtropical and tropical estuaries. In Annual Progress Report, 1975-76. Miami University, Florida.

Treshow, M.

1970 Enviroment and plant response. McGraw-Hill Book Co., New York.

Whelan, T., J. Ishmael, and W.S. Bishop.

1976 Long-term chemical effects of petroleum in South Louisiana wetlands. Organic carbon in sediment and waters. Marine Pollution Bulzetin 7(8).

Wilson, J.S., J.R. Hamilton, J.A. Manning, P.E. Muehlberg

1977 Environmental assessment of geopressured waters and their projected uses. Industrial Environmental Research Laboratory, U.S. Environmental Protection Agency, 600/7-77-039.

Zobell, C.E.

1973 Microbial degradation of ofl: present status, problems and perspectives. In The microbial degradation of oil pollutants, edited by D.G. Ahearn and S.P. Meyers. Center for WetZand Resources, Louisiana State University LSU-SG-73-01:3-16. 
CHAPTER SIX - COORDINATION WITH FEDERAI, STATE, REGIONAL, AND LOCAL AGENCIES

\subsection{Programs and Permits}

Programs, regulations, guidelines and permits have been developed for geopressured activities by several Federal, state, regional and local agencies. Some of these agencies also have regulations or permit requirements for several activities involved in geopressured exploration and development (Harrell et al., 1978).

A list of agencies contacted at all levels of government appears in Appendix C. An asterick identifies those that responded.

\subsubsection{Federal}

Federal agencies which have programs, rules or permit requirements concerning geopressured activities or any other activities related to this resource exploration and development are identified in Table 6-1. Major Federal legislation concerning particular valuable resources is identified in Table 6-2.

\subsubsection{State}

State agencies which have programs, rules, guidelines or permit regulations concerning geopressured activities or any other activities related to this resource exploration and development are Identifled in Table 6-3. Louisiana state rules and regulations concerning the drilling for and production of geopressured resources in the state of Louisiana are compiled under Statewide Order No. 29-P, avallable at the Louisiana office of Conservation, Baton Rouge, Loulsiana, Forms that must be submitted for the drilling and production of geothermal resources appear in Table 6-4. 
Table 6-1. Matrix of Federal Action on Geopressured Well Testing Activities and Related Oil Activities.

rederul agenctes

Bureav of Land Manegement
(Dept. of the Interlor)

Herituge Conserv. Hee. Service (Dept. of Interior)

v.s. Army Corpe of Englneers of of

Depl. of Commeree, Couct 4

Ceodetse Survey, MOM

Enviromental Protection

Ageney

Pederal Eneray Regulatory

Comaloution

U.3. Goologieal survey

Interatate comerce

comitention

0.8. Conet Gund

at af

v.s. Floh 6 w11d11E Servlee

(Dept. of the Interior)

Woter Resourcen Counc11

Departwent of Energy

Adrisory Coune1l on Mintoric

Preacruation

Execut 1ve Order:

Ploodplaln Manegeanent

Protection of Watlende

or

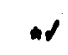

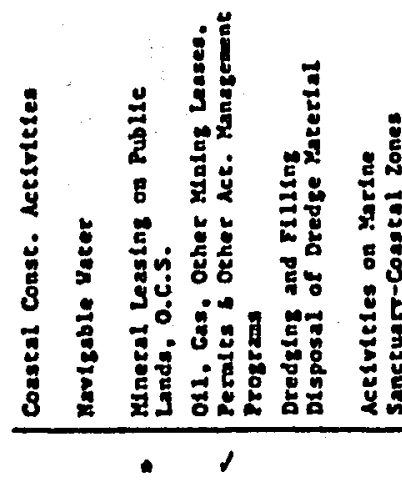

$\bullet$

Aponedoe Requiring Pormite
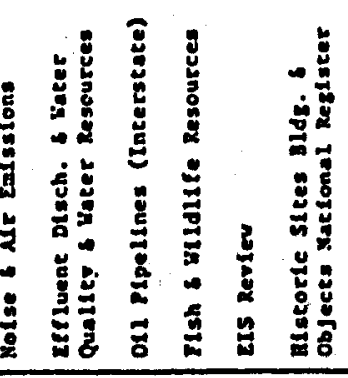

$\boldsymbol{x}$.

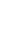

43 usch p. 1 tot eeq.

I0 usca po iso it 16 us

460, 16 usca p. 460 1-4

33 usea see. 108 (1960): 33 usca see. 404 (1960): nucc see 404-33 uses: See. 1346 (Supp 1976)

Coestal Zone Management Aet (1972) P.L. Mo. 92-583, 86 stet. 1280. V.s.c. pp. 1431 et eeq. 3 is usea pp. 311, 330.2 usch po 1501 at mee.

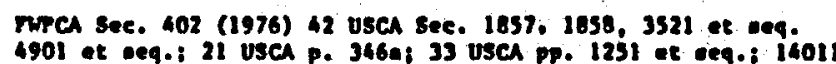
usc p. 135 et eeq.; 18 useh pp. 791-825r; 49 usen pp. 1671-1684; is usca p. 717 et eeq.

43 usen p. 1334, 1337; 43 used po 31 et eeq. 130 usch p. 331 et neq.
14

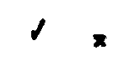

$+\times$

1 49 usch p. I ot meq.: 49 usca p. 302 at meq.: as usca p. 801 et exq. i he usca p. 1001 ot eeq.

33 usca P. $1221:$ is usca p. 326: 33 usca p. 14d: 33 vsca

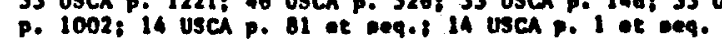
16 usca pp. 742a-742k; 16 usCA p. 1361 et eeq.

42 usca p. 1962 et eeq.; Zed. Mon-Muclonr Energy Ree. + Dev. Net, 1974. Sec. 13

42 usca p. 5012 at eeq.; 12 usCA p. 2011 et. oeq.; Ped. Non-Muelear Energy Rea. L Dev. Act, 1974, sec. 13; 30 usCA pp. 661-668

16 USCA 461-67; USCA 470-470 an amended, 1973; 42 usch 4321 et aeq. 1970

Execut1ve Order 11988. May 24, 1977

Execut 1ve Order 11990. Kay 24, 1977

Agency Revlewe ers and RA or

x Aponcy hos Rulae and Rosulationa
Applylns to Aetion 
Table 6-2. Major Federal Legislation Pertaining to Valuable Resources.

Resources Federal Legislation

Water. - . - . . . . . Federal Water Pollution Control Act

Alr. . . . . . . . . Clean Air Act

Endangered Flora and Fauna ..... Endangered Species Act

Floodplains and Erosion Hazard Areas. Flood Insurance Act

Barrier Island and Beaches .... Coastal Zone Management Act

Historic and Cultural Resources. - National Historic Preservation Act

Wildlife Refuges and Reserves. . . Pitman-Robinson Act; Dingal1Johnson Land and Water Conservation Fund Act

Areas of Unique Cultural Significance. National Historic Preservation Act Minerals . . . . . . . . Mineral Leasing Act

Prime Agricultural Lands . . . . Homestead Act

Forests. . . . . . . . National Forest Management Act .

Living Marine Resources. - . - . Fisheries Conservation and Management Act; Marine Mamai Protection Act

Coastal Resources. . . . . . Federal Consistency Provisions of the Coastal Zone Management Act

Prime Farmlands. . . . . . Section 302 Rural Development Act

Note: For more extensive data concerning Federal programs, rules and regulations pertaining to geothermal and goepressured resources, see Department of Energy (DOE), 1978.

Source: Federal Register, 1978a, 1978b; Mangum, 1978. 
Table 6-3. Matrix of State Actions of Geopressured Well Testing Activities and Related 011 Activities.

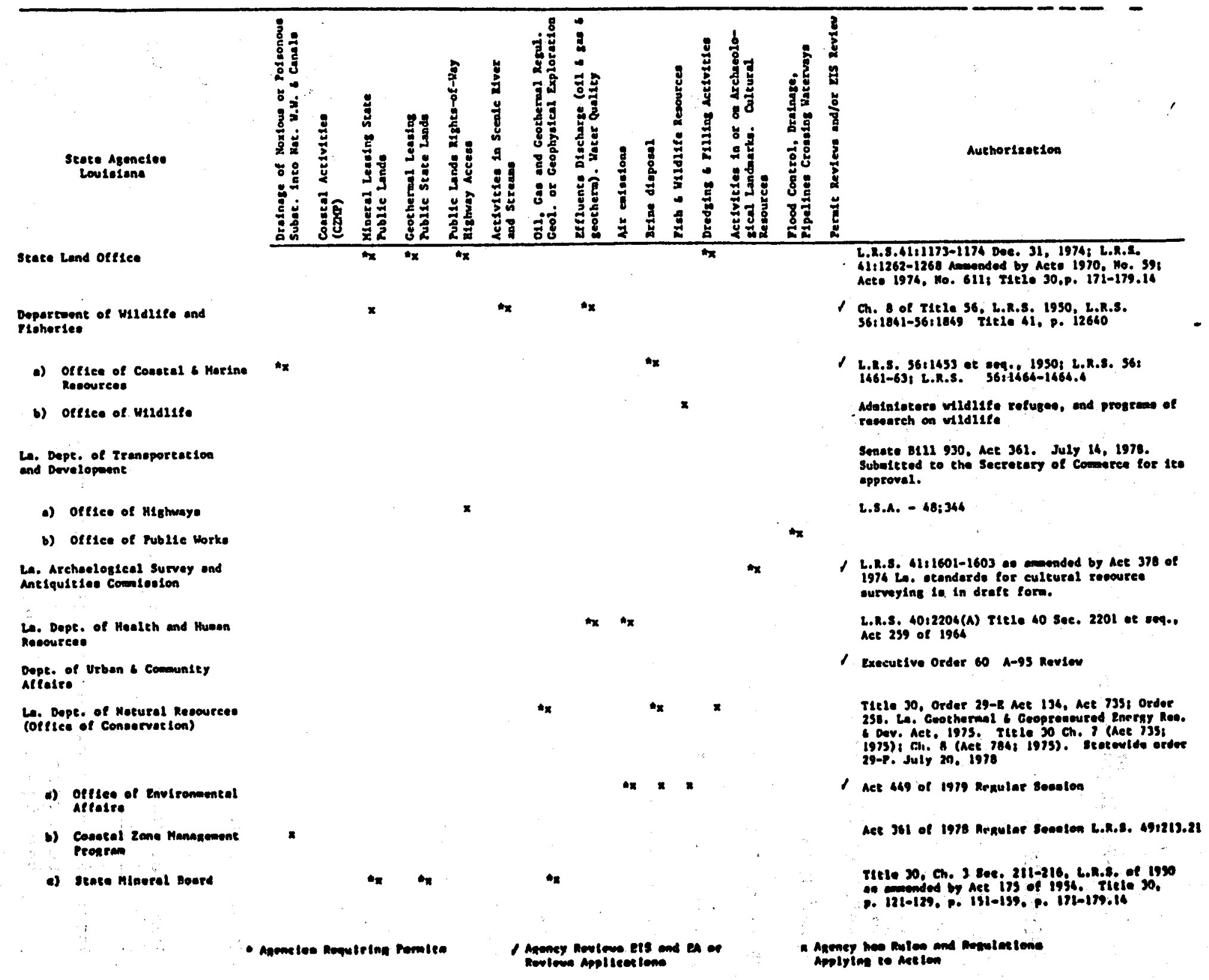


Table 6-4. Forms that must be Submitted in the State of Louistana for the Drilling and Production of Geopressured Resources.

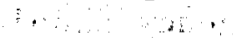

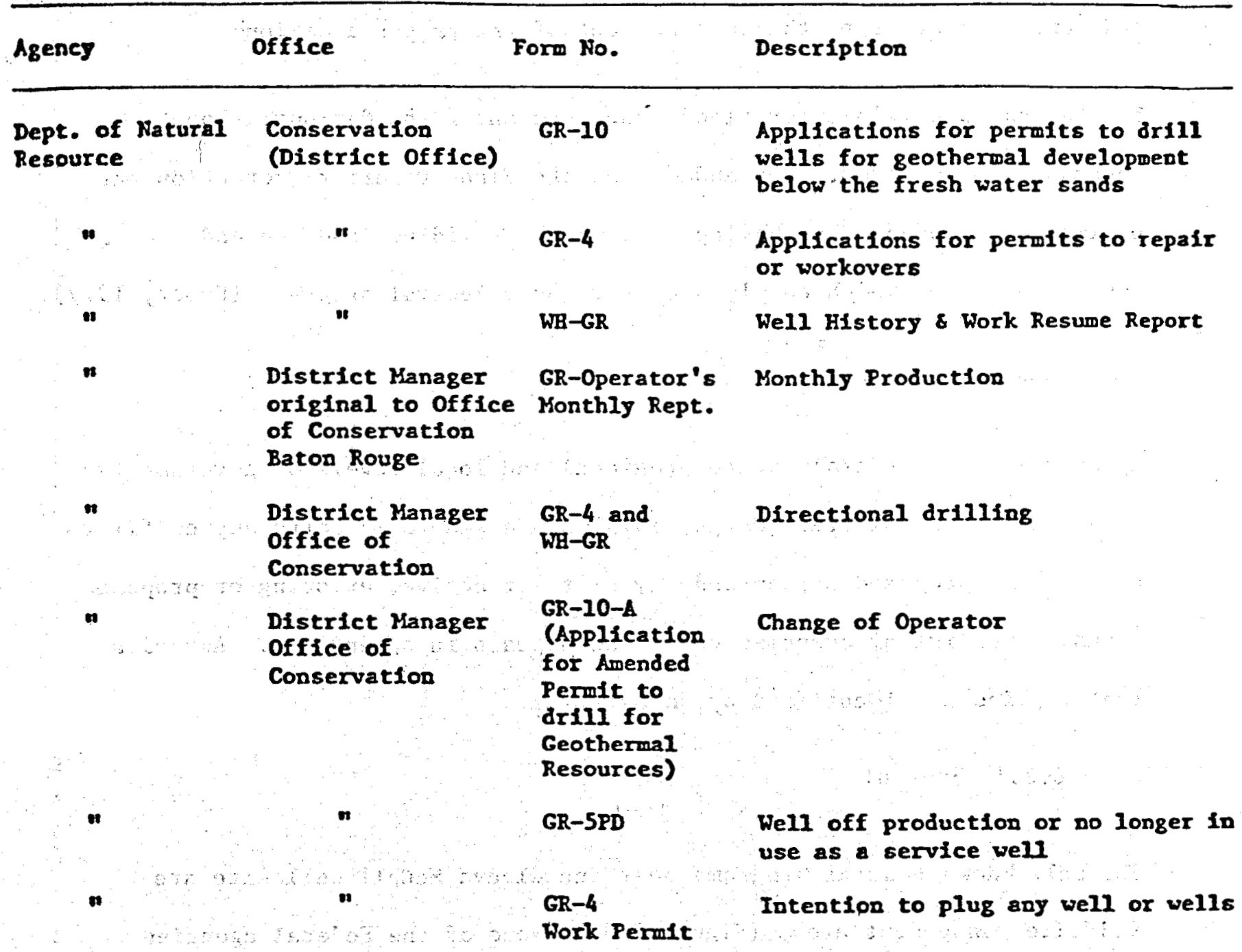




\subsubsection{Regional and Local}

The Cameron Parish Police Jury is the only regional and local government body with executive and legislative power. This agency should be notified and contacted prior to the commencement of the proposed action.

The Parish is eligible for flood insurance under the National Flood Insurance Act of 1968, as amended, and the Flood Disaster Protection Act of 1973 as amended, thus having ordinances providing land use and control measures which comply with the above Federal programs (Emmer, 1977 ).

\subsection{Land Use Plans}

Agencies at the Federal, state, regional and local levels of government were contacted by letter (May 8, 1979) and asked to identify any conflicts between the proposed action and any of their active, existing or proposed plans. The list of agencies contacted appears in Appendix $c$. Agencies that replied are identified by an asterick.

\subsubsection{Federal}

The only known Federal programs near the Gladys McCall well site are wildlife management areas (Figure 2-8). None of the Federal agencies contacted who replied have any conflicts with the proposed action. All other agencies contacted who have not replied are assumed to have no conflicts between the proposed action and their plans.

\subsubsection{State}

All state agencies contacted regarding conflicts of their plans with the proposed action are listed in Appendix $C$. Those that responded did not 
find any conflicts, other than that the proposed action will have to comply with their guidelines, rules and permit requirements.

\subsubsection{Regional}

The Imperial Calcasieu Regional Planning and Development Commission (ICRPDC, 1975) shows the future land use of the area through 1990 to be non-forested wetland. There are no other known land use plans for the area.

\section{2 .4 Local}

Although there is no local or Parish planning agency adopted or future land use plan, the Paxish is eligible for the National Flood Insurance Program (Emmer, 1977), an indirect form of land use control. 
REFERENCES

Department of Energy (DOE)

1978 A preliminary environmental assessment of selected geopressuredgeothermal prospect areas: Louisiana Gulf coast region, Vol. II. Institute for Environmental Studies, Louisiana State University.

Emmer, Rod E.

1977 Flood insurance: a case study of a federal land-use program in the Louisiana coastal zone. Geoscience and Man XVIII:299-304.

Federal Register

1978a Federal Register Vol, 43, No. 41, March 1, 1978.

1978b Federal Register Vol. 43, No. 49, March 13, 1978.

Harrell, Thomas A., Michael Ky, Ralph W. Pike, Bert Wilkins 1978 Legal problems inherent in the development of geopressured and geothermal resources in Louisiana.

Imperial Calcasieu Regional Planning and Development Commission 1975 Future land use plan for 1990. ICRPDC, Lake Charles, June.

Mangum, A.

1978 Personal communication with Alton Mangum, State Conservationist, July 19, 1978,

$6-8$ 


\subsection{Delay}

This project is designed to drill a well into a geopressure reservoir to evaluate the reservoir potential over a sustained period of flow testing. Several previous well tests in Louisiana were in abandoned oil and gas wells, and although they provided important data, they were not in the optimum location to test geopressured reservoir economics. The delay of this project will restrict the availability of geopressured reservoir data on geopressure exploration techniques and will severely restrict the amount of information available on the geopressured resource.

\subsection{No Build}

The No Build alternative is not consistent with Congressional mandate as directed by the Geothermal Energy Research, Development and Demonstration Act of 1974 (U.S. Congress, 1975). This act directs the Federal Government to encourage and assist private industry in the development and demonstration of practicable means of producing energy from geothermal resources in an environmentaliy sound manner. This assistance is to Include resource assessment and research and development projects.

\subsection{Alternative Approaches}

The DOE, through the geopressure subprogram, is evaluating alternative methods for obtalning the necessary chemical and physical data on the geopressure resource. One method is to conduct a literature search of 
published and unpublished reports or data. A second method is to redrill ofl wells after they have been abandoned and the rigs are moved from the location. The literature search has not provided the necessary data in a form which is required to evaluate the resource. Schmidt (1973), Hankins et al. (1977), Wilson et al. (1977) and Karkalits and Hankins (1978) provide some basic data, but not in sufficient quantity or in the optimum location for future development of the resource. Redriling of abandoned oil or gas wells is economical, but the wells do not always occur in optimum resources areas. It becomes a decision, then, of whether to expend limited funds for projects which may never be developed because of physical, cultural, or economic constraint.

\subsection{Alternative Sites}

As part of the Geopressured Geothermal Energy Subprogram, DOE conducted a reservior assessment program in order to determine the extent of the geopressured resource and to identify specific areas with high potential for successfully testing and developing the resource. These areas, identified as geopressure fairways in Texas and prime prospects in Louisiana, are characterized by thick, geopressured sandstones with subsurface temperatures in excess of $150^{\circ} \mathrm{C}\left(300^{\circ} \mathrm{F}\right)$.

Prime prospects or fairways for the Frio, Wilcox, and Tuscaloosa Formations in Louisiana and Texas were identified as part of the reservoir assessment program and were prioritized based on technical and environmental criteria. This prioritization scheme provides a relative ordering of the areas, i.e., it indicates that one prime prospect or fairway is preferable to another. 
The rank assigned of ten reflects the lack of complete and/or comparable information for al1 sites. A low ranking does not exclude a prospect from further design well activities but rather indicates that the activities will be conducted later in the program after additional information has been obtained.

During the evaluation process, efghteen sites in Loulsiana and Texas were identified and ranked according to technical issues (e.g., sand thickness, permeability, and salinity) and environmental issues (e.g., presence of floodplains, wetlands, prime farmlands, or endangered species). The Gladys McCall well site ranked high on technical 1ssues, however, several environmental concerns, such as Impacts on wetlands and aquatic ecosystems and potential effects of storm surges, caused the prospect to receive a low environmental ranking. Locating the project on an existing well site reduces the impacts to an acceptable level and therefore the proposed site was selected. The Sweet Lake No. 1 well in Cameron Parish, Louisiana was rated highest and drilling and testing activities are currently underway (DOE, 1980). Selection of the exact location of the well site within the prime prospect is Iimited by technical factors (e.g., location relative to the geologic structure and sediment depocenters), environmental factors (as described in this environmental assessment), and lease availability. The proposed well site is located in an area that has high potential for obtaining the desired programmatic information while at the same time restricting impacts to an environmentally acceptable level by utilizing an existing we1l site. 


\section{REFERENCES}

Hankins, B.E., R.E. Chavanne, R.A. Ham, O.C. Karkalits, and J.I. Palermo

1979 1977 chemical analysis of geothermal waters from a south Louisiana well. Third Geopressured-Geothermal Energy Conference ED67-ED93.

Rarkalits, D.C. and Hankins B.E.

1978 Chemical analysis of gas dissolved in geothermal waters in a south Louisiana well. Proceedings: Third Geopressure-Geothermal Energy Conference, November 16-18, 1977.

Schmidt, G.W.

1973 Interstitial water composition and geochemistry of deep Gulf coast shales and sandstones. American Association of Petroleum Geology V57(2):321-337.

United States Congress

1975 Geothermal energy research, development and demonstration act of 1974. PL93-410; September 3, Section 2.12.

Wilson, J.S., J.R. Hamilton, J.A. Manning, and P.E. Muehlberg

1977 Environmental assessment of geopressured waters and their projected uses. Industrial Environmental Research Laboratory, U.S. Environmental Protection Agency 600/7-77-039 


\section{Appendices}

APPENDIX A

\section{ENVIRONMENTAL MONITORING PLAN: \\ DOE GLADYS MCCALL GEOPRESSURE TEST WELL}

\section{INTRODUCTION}

A DOE contractor will manage environmental baseline and monitoring studies for geopressure test well activities at a site adjacent to Gladys McCall No. 1 in southeastern Cameron Parish, Loulsiana. The drilling and testing operations associated with the Gladys McCall geopressure test well will be conducted within the scope of this environmental assessment.

ENVIRONMENTAL BASELINE AND MONITORING STUDIES

The purpose of collecting environmental baseline data is to provide a description of selected physical, chemical, and biological conditions against which later environmental monitoring data can be compared. This comparison will provide a basis for determining the net environmental change attributable to test well operations at any subsequent time.

The following data shall be collected to establish the baseline of ambient conditions prior to fluid production:

Air Quality

- existing air quality conditions

- local meteorological characteristics

Water Quality (surface and subsurface)

- existing water quality conditions

- water resource usage

- hydrologic patterns, surface and groundwater levels and water movement

Subsidence

- subsidence history

- leveling surveys

- existing land/water interface 
Seismicity

- reconnaissance and baseline microseismic surveys

Ecosystem Quality

- biological surveys

In order to avoid duplication, information presented in the DOE/Oak Ridge Environmental Impact Assessment for the Gladys McCall well test shall be incorporated where possible in the environmental baseline evaluation. For example, very little additional work may be required to establish existing ecosystem quality.

An environmental monitoring program designed to provide comparative data during drilling and production phases will include the studies listed below. The aster1sk (*) indicates the studies that are contigent upon the occurrence of environmental changes (e.g., changes in air quality and/or standards violation in the case of air quality) and are not considered in the base scope of work. Air Quality

- air quality monitoring

- pollutant dispersion modeling*

- continuous wind speed, wind direction, temperature and precipitation

Water Quality (surface and subsurface)

- existing water quality conditions

- water resource usage

- hydrologic patterns, surface and groundwater levels and water movement

Subsidence

- repeated leveling surveys

- geomophorphologic studies and mapping of changes in land/water interface

Seismicity

- continuous microseismic monitoring 


\section{Ecosystem Quality \\ - biological surveys* \\ - bioassays*}

Monitoring studies may be increased if environmental conditions, either natural or as a result of test well activities and geopressure fluid analysis, require such adjustment.

The combined scope of environmental baseline and monitoring studies which are planned during the first year includes the air quality, water quality, subsidence, microseismic and ecological studies described below.

1) Air Quality. Air quality baseline studies will be performed to:

1) determine ambient air quality prior to possible disturbance from test well activities; 2) identify any substance potentially derived from the geopressured fluid that may have an adverse effect on the environment and establish baseline concentrations for these substances; 3) collect locally available meteorological data necessary for understanding dispersion and conversion patterns; and 4) provide baseline data compatible with later measurements needed to assure compliance with state and Federal air quality standards.

Air quality monitoring will be performed to determine changes in air quality which may be related to well testing activities. Sampling and analysis for hazardous substances will be from a fixed automated monitoring unit located approximately $3.2 \mathrm{~km}(2 \mathrm{mi})$ north of the test site (prevailing winds are from the south). Analyses will include continuous measurement of sulfur dioxide, hydrogen sulfide, total hydrocarbons, and methane. Meteorological data from continuous recorders shall include 
wind speed, wind direction, temperature, and precipitation. In the event of significant atmospheric pollutant emissions, dispersion characteristics will be determined.

Analytical procedures for air quality monitoring will be consistent with designated Reference or Equivalent Methods published by the U.S. Environmental Protection Agency, Monitoring and Research Laboratory, Research Triangle Park, North Carolina, November 3, 1978. Analyzer performance shall conform to specifications for automated methods as described in $40 \mathrm{CFR}$, Parts 50 and 53.

2) Water Quality. Water quality baseline studies will be conducted to determine: 1) ambient water quality conditions in local bayous and marsh and in shallow groundwater prior to possible disturbance from test well activities; 2) baseline conditions for substances potentially present in the geopressured fluids; and 3) water resource usage and baseline concentrations for substances and physical properties for which state standards have been established.

Water quality monitoring studies will be performed so that changes in chemical and physical properties of surface and groundwater can be determined. Surface water samples will be collected monthly at three locations in the marshes and bayous south of the test site. A water level gauge or staff will be established at each sample location. Surface water levels will be recorded at the time of sample collection. Laboratory analyses will include $\mathrm{Na}, \mathrm{K}, \mathrm{NH}_{3}, \mathrm{SO}_{4}, \mathrm{Cd}, \mathrm{Mn}, \mathrm{Ca}, \mathrm{Cl}, \mathrm{Ba}, \mathrm{Pb}$, As, $\mathrm{B}, \mathrm{Hg}$, total hardness (calculated), and total organic carbon. Field measurements will include $\mathrm{pH}$, specific conductance, turbidity, temperature and dissolved oxygen. 
Three observation wells will be drilled into the zone of fresh groundwater which is used locally by residents of Grand Chenier Ridge. These wells will be completed at a depth of approximately 76 m (250 ft), in the "upper sand unit" of the Chicot Aquifer. Observation well casing will consist of $5 \mathrm{~cm}$ ( 2 in) diameter PVC pipe with $3 \mathrm{~m}(10 \mathrm{ft})$ of PVC wrapped wire screen with backwash valve placed at we1l bottom. The wells will be concrete-lined down to at least 2 -ft $(.6 \mathrm{~m})$ below the surface to prevent drainage of surface water. The exposed portion of each well will be completed with a removable cap which will allow sampling by portable pump.

Groundwater samples will be collected each month. Field and laboratory. analyses to be performed on groundwater samples will be the same as for surface waters. Water level in the observation wells will be reported monthly. Surface and groundwater sample collection, handling, preservation and analysis will be consistent with methods published by the $0 . S$. Environmental Protection Agency, "Manual of Methods for Chemical Analyzers of Water and Wastes" (1974), and the U.S. Geological Survey, "Recommended Methods for Water Data Acquisition" (1977).

3) Subsidence. Subsidence baseline studies will include 1) an initial leveling survey to establish relative surface elevations; 2 ) an examination of historic leveling data and topographic maps to determine subsidence history in the vicinity of the test well; and 3) detailed mapping of near sea-level marsh environments which are most vulnerable to elevation change.

The initial leveling survey shall consist of approximately $48 \mathrm{~km}$ (30 mi) of First-Order precise leveling. Leveling profiles will be tied to 
National Oceanic and Atmospheric Administration (NOAA) First-Order elevation benchmarks which are located along Highway 82 beyond the area of potential subsidence impact. Procedures to be used in establishing benchmarks in the vicinity of the test well will be in accordance with guidelines provided in the NOAA publication, "Specifications to Support Classification, Standards of Accuracy, and General Specifications of Geodetic Control Surveys" (1978).

Subsidence monitoring will consist of First-Order releveling surveys which will be conducted at 12-month intervals during production to document the occurrence of land-surface subsidence, if any, near the well site, or of differential surface movement along reactivated faults. First-Order releveling is planned during the second-year environmental monitoring program, and is not considered in the base scope of work for this proposal.

Detailed maps of wetland boundaries and open water in the vicinity of the test well will be prepared prior to fluid production. After the flow testing program has been completed, a second series of maps wili be prepared to determine changes in land/water interface which may be attributable to subsidence. Mapping studies will be based upon current aerial photography, topographic sheets, and field surveys.

4) Seismicity. Microseismic surveys will be performed to 1) determine background microseismic activity prior to disturbance from fluid production; and 2) monitor microseismic activity during fluid production. Baseline microseismic studies will include an initial reconnalssance 
survey to determine sources and levels of background microseismic activity. Data from this survey will be used to identify locations for permanent monitoring installations which will be least influenced by natural and cultural background noise.

Continuous microseismic monitoring will be performed using a minimum of five seismometers emplaced in sealed boreholes at approximately $30 \mathrm{~m}$ (100 ft) below ground surface. Microseismic monitoring studies will provide the origin time of local seismic events, their estimated locations, and their relative magnitudes. The microseismic monitoring net will be operative approximately six months prior to fluid production.

5) Ecosystem Quality. Baseline ecological studies will rely on existing published and unpublished data to establish ranges and populations of plant and animal species in the vicinity of the test well. Additional biological surveys will be conducted in the event of significant impact to plant or animal life but are not considered part of the base scope of work.

\section{ENVIRONMENTAL PROGRAM MANAGEMENT}

The environmental monitoring program will be coordinated by a principal of Technadril-Fenix \& Sisson and LSU. The management of environmental monitoring will include insuring that data collected are compiled, analyzed, and reported to DOE on a quarterly basis, or more frequently, if necessary. The DOE contractor will provide for contractual arrangements with firms for performance of selected field and laboratory studies. Overall data interpretation and Impact assessment will be performed by the DOE contractor. The DOE contractor 


\section{A-8}

will also be responsible for determining if Federal, state, and local environmental quality standards are being met, and will inform DOE in the event of non-compliance. Investigators for the contractor will also inform DOE when an increase or decrease in baseline monitoring studies is required, justifying such changes in scope as they occur.

This Environmental Monitoring Plan outlines a one-year program of combined environmental monitoring and baseline studies. The DOE contractor will prepare quarterly status reports, and an annual report summarizing the results obtained during the first year. Based on analysis of the data, the development of the test well, and the Federal, state, and local regulations, the DOE contractor will propose a second-year plan for continuing air quality, water quality, subsidence and microseismic monitoring studies. In preparing this plan, the DOE contractor will determine whether or not it can be accomplished at a reduced level in any of the monitoring programs (e.g., increasing the interval between water samples or reducing the number of ions analyzed). 
Table B-1. Plant Species Observed Within the Impounded Marsh in the Study Area.

COMMON NAME

Wire grass

Saltgrass

Roseau cane

Leafy three-square

Softstem bulrush

Giant cutgrass

Widgeon grass
SCIENTIFIC NAME

Spartina patens

Distichlis spicata

Phragmites communis

Scirpus robustus

Scirpus validus

Zizaniopsis miliacea

Ruppia maritima 
Table B-2. Plant Species Observed on Plank Road and Spoil Banks Within Gladys McCall Proposed Well Site.

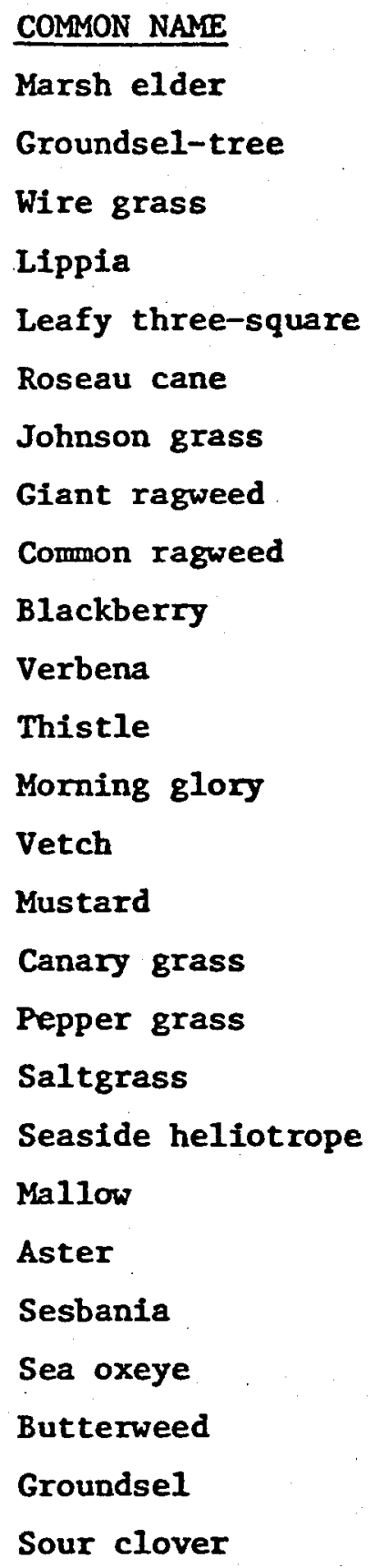

SCIENTIFIC NAME

Iva frutescens

Baccharis halimifolla

Spartina patens

Lippia nodiflora

Scirpus robustus

Phragmites communis

Sorghum halapense

Ambrosia trifida

Ambrosia artimisifolia

Rubus sp.

Verbena sp.

Cirsium sp.

Ipomea sp.

Vicia sp.

Brasica sp.

Phalaris canariensis

Lepidium virginicum

Distichlis spicata

Heliotropium curassavicum

Hibiscus sp.

Aster sp.

Sesbania exaltata

Borrichia frutescens

Senecio glabellus

Senecio vulgaris

Melilotus indica 
Table B- Plant Species Observed Along Highway 82, Within the Gladys McCall Study Area.

COMMON NAME

Cottonwood

Populus deltoides

Live oak

Quercus virginiana

Black willow

Salix nigra

Hackberry

Celtis laevigata

Chinaberry

Mel1a azedarach

Palmetto

Sabal minor

Roseau cane

Phragmites communis

Blackberry

Rubus sp.

Thistle

Cirsium sp.

Peppergrass

Lepidium virginicum

Morning glory

Ipomea sp.

Primrose

Oneothera drummondil

Wild grape

Vitis sp.

Cattail

Typha latifolla

Smut grass

Sporobolus poiretii

Verbena

Verbena brasiliensis

Verbena

Giant ragweed

Verbena sp.

Ambrosia trifida

Conmon ragweed

Ambrosia artimisifolia

Groundsel-tree

Baccharis halimifolia

Arrowhead

Sagittaria falcatta

Wax myrtle

Myrica cerifera

Dock

Rumex sp.

Crabgrass

Digitaria sp.

Vetch

Vicia sp.

Toadflax

Linaria canadensis

Peppervine

Ampelopsis arborea

wild onion

Allium sp. 
Table B-3 (continued)

COMMON NAME

Bald cypress

Japanese honey suckle

Wild geranium

Aster

Inland sea oats

Johnson grass

Indian shot
SCIENTIFIC NAME

Taxodium distichum

Lonicera japonica

Geranium carolinianum

Aster sp.

Chasmanthium latifolium

Sorghum halapense

Canna sp. 
Table B-4. Mammal Species Which May Occur in the Chenier Plain Marshes of the Study Area.

COMMON NAME

Virginia opossum

Least shrew

Red bat

Seminole bat

Northern yellow bat

Nine-banded armadillo

Swamp rabbit

Marsh rice rat

Fulvous harvest mouse

Hispid cotton rat

Muskrat

Nutria

Red wolf

Black bear

Raccoon

Mink

Striped skunk

Neartic river otter

White-tailed deer

Source: Lowery, 1974b
SCIENTIFIC NANE

Diadelphis virginiana

Cryptotis parva

Lasiurus borealis

Lasturus seminolus

Lasiurus intermedius

Dasypus novemcinctus

Sylvilagus aquaticus

Oryzomys palustris

Reithrodontomys fulvescens

Sigmodon hispidus

Ondatra zibethlcus

Myocastor coypus

Canis rufus

Euarctos americanus

Procyon lotor

Mustela vison

Mephit1s mephitis

Lutra canadensis

odocolleus virginianus 
Table 3-5. Bird Species known to Nest on Spoll Banks in Rockefeller Wildlffe Refuge, Cameron Parish, Louisiana.

COMMON NAME

Red-winged blackbird

Boat-tailed grackle

Green heron

Orchard oriole

Least Bittern

Eastern kingbird

Common yellowthroat

Cardinal

Loggerhead shrike

Mockingbird

Yellow-billed cuckoo

Rufous-sided towhee

Brown thrasher

Clapper rail

Source: Olsen, 1975
SCIENTIFIC NAME

Agelaius phoeniceus

Cassidix major

Butorides virescens

Icterus spurius

Ixobrychus exilis

Tyrannus tyrannus

Geothlypis trichas

Cardinalis cardinalis

Lanius Iudovicianus

Mimus polyglottos

Coccyzus americanus

Pipilo erythrophthalmus

Toxostoma rufum

Rallus longirostris 
Table B-6. B1rd Species Known to Nest in Intermediate Marshes in Rockefeller Wildlife Refuge, Cameron Parish, Louistana.

COMMON NAME

Red-winged blackbird

Boat-tailed grackle

Least bittern

Mottled duck

Seaside sparrow

Black-necked stilt

Source: Olsen, 1975
SCIENTIFIC NAME

Agelaius phoeniceus

Cassidix major

Ixobrychus exilis

Anas fulvigula

Ammospiza maritima

Himantopus mexicanus 
Table B-7. Reptiles and Amphibians Which May Occur Within the Study Area.

COMMON NAME

American alligator

Alligator snapping turtle

Common snapping turtle

Stinkpot

Razor-backed musk turtle

Mississippi mud turtle

Mississippi map turtle

Southern painted turtle

Mobile cooter

Missouri slider

Red-eared turtle

Three-toed box turtle

Ornate box turtle

Western chicken turtle

Midland solftshell turtle

Pallid spiny softshell

Green anole

Ground skink

Five-lined skink

Broad-headed skink

Western slender glass skink

Broad-banded water snake

Yellow-bellied water snake

Diamond back water snake

Green water snake

Gulf glossy water snake

Graham's water snake

Eastern garter snake
SCIENTIFIC NAME

Alligator mississippiensis

Macroclemys temincki

Chelydra serpentina serpentina

Sternotherus odoratus

Sternotherus carinatus

Rinosternum subrubrum hippocrepis

Graptemys kohni

Chrysemys picta dorsalis

Chrysemys concinna mobilensis

Chrysemys floridana hoy 1

Chrysemys scripta elegans

Terrapene carolina

Terrapene ornata

Deirochelys reticularia miaria

Trionyx muticans

Trionyx spiniferus

Anolis carolinensis

Leiolopisma laterale

Eumeces fasciatus

Eumeces laticeps

Ophisaurus attenuatus attenuatus

Natrix fasciata confluens

Natrix erythrogaster flavigaster

Natrix rhombifera

Natrix cyclopion cyclopion

Natrix rigida sinicola

Natrix grahmi

Thamnophis sauritus sauritus 
Table B-7 (continued)

COMMON NAME

Gulf coast ribbon snake

Brown snake

Gulf salt marsh snake

Mississippi ringneck snake

Eastern hognose snake

Rough green snake

Western mud snake

Texas rat snake

Louisiana milk snake

Speckled kingsnake

Western cottonmouth

Southern copperhead

Pygmy rattlesnake

Western lesser siren

Three-toed amphiuma

Central newt

Sma11-mouthed salamander

Marbled salamander

Dwarf salamander

Eastern narrow-mouthed toad

Gulf coast toad

Nor thern spring peeper

Green tree frog

Squirrel tree frog

Northern cricket frog

Bronze frog

Pig frog

Bull frog

Southern leopard frog

\section{SCIENTIFIC NAME}

Thamnophis proximus orarius

Storeria dekay 1

Natrix sipedon clarki

Diadophis punctatus

Heterodon platyrhinos

Opheodrys aestivus

Farancia abacura reinwardti

Elaphe obsoleta lindheimeri

Lampropeltis triangulum amaura

Lampropeltis getulus

Agkistrodon piscivorus leusostama

Agkistrodon contortrix contortrix

Sistrurus miliarus

Siren intermedia nettingi

Amphiuma tridactylum

Notophthalmus viridescens

Ambystoma texanum

Ambystoma opacum

Durycea quadridigitata eurycea

Gastrophryne carolinensis

Bufo valliceps

Hyla crucifer crucifer

Hyla cinerea

Hyla squirella

Acris crepitans

Rana clamitans

Rana grylio

Rana catesbeiana

Rana utricularis 
Table B-8. Fish Species That May Occur in the Study Area.

COMMON NAME

Atlantic Stingray

Lady fish

Gulf menhaden

Bay anchovy

Sea Catfish

Atlantic Needlefish

Sheepshead Minnow

Rainwater Killifish

Striped mullet

White mullet

Tidewater Silverside

Southern Flounder

Hog choker

Spotted Gar

Alligator Gar

Bowfin

American eel

Speckled worm eel

Atlantic herring

Gizzard shad

Threadfin sahd

Scaled sardine

Inshore lizard fish

Carp

Golden shiner

Blue catfish

Yellow Bullhead

Channel catfish
SCIENTIFIC NAME

Dasyatis sabina

Elops saurus

Brevaortia patronus

Anchoa mitchilli

Arius felis

Strongylura marina

Cyprinodon variegatus

Lucania parva

Mugil cephalus

Mugil curema

Menidia beryllina

Paralichthys lethostigma

Trinectes maculatus

Lepisosteus oculatus

L. spatula

Amia calva

Anguilla rostrata

Myrophis punctatus

Clupea harengus harengus

Dorosoma cepedianum

Dorosoma pretense

Harengula pensacolae

Synodus foetens

Cyprinus carpio

Notemigonus crysoleucas

Ictalurus furcatus

Ictalurus natalis

Ictalurus punctatus 
Table B-8 (continued)

COMMON NAME

Gafftopsail catfish

Atlantic midshipman

Skillet fish

Mosquito fish

Sailfin molly

Gulf pipefish

Yellow bass

Warmouth

Bluegill

Redear Sunfish

Spotted sunfish

Largemouth bass

White crappie

Black crappie

Killifish

Crevalle jack

Atlantic bumper

Leatherjacket

Atlantic moonfish

Lane snapper

Sheepshead

Pinfish

Freshwater drum

Silver perch

Sand seatrout

Spotted seatrout

Banded drum

Spot

Southern kingfish

Atlantic croaker

Black drum
SCIENTIFIC NAME

Bagre marinus

Porichthys porosissimus

Gobiesox strumosus

Gambusia affinis

Poecilia latipinna

Syngnathus scovelli

Morone mississippiensis

Lepomis gulosus

Lepomis macrochirus

Lepomis microlophus

Lepomis punctatus

Micropterus salmoides

Pomoxis annularis

Pomoxis nigromaculatus

Fundulus spp.

Caranx hippos

Chloroscombrus chrysurus

oligoplites saurus

Vomer setapinnis

Lutjanus synagris

Archosargus probatocephalus

Lagodon rhomboides

Aplodinotus grunniens

Bairdiella chrysura

Cynoscion arenarius

Cynoscion nebulosus

Larimus fasciatus

Leiostomus xanthurus

Menticirrhus americanus

Micropogon undulatus

Pogonias cromis 
Table B-8 (continued)

COMMON NAME

Red Drum

Atlantic spadefish

Atlantic threadfin

Freckled blenny

Fat sleeper

Spinycheck sleeper

Lyre goby

Violet goby

Sharptail goby

Freshwater goby

Naked goby

Clown goby

Atlantic cutlassfish

Harvest fish

Gulf butterfish

Searobin

Blackcheek tonguefish

Southern puffer

Source: Perry, 1976
SCIENTIFIC NAME

Sciaenops ocellata

Chaetodipterus faber

Polydactylus octonemus

Hypsoblennius ionthas

Dormitator maculatus

Eleotris pisonis

Evorthodus lyricus

Gobioides broussonnet1

Gobionellus hastatus

Gobionellus shufeldti

Gobiosoma bosc1

Microgobius gulosus

Trichiurus lepturus

Peprilus alepidotus

Peprilus burti

Prionotus sp.

Symphurus plagiusa

Sphoeroides nephelus 
Table B-9. Waterfowl Species Which May Occur in the Study Area.

COMON NAME

White-fronted goose

Snow goose

Fulvous tree duck

Mallard

Black duck

Mottled duck

Gadwall

American pintail

Green-winged teal

Blue-winged teal

American widgeon

Shoveler

Wood duck

Redhead

Ring-necked duck

Canvasback

Lesser scaup

Bufflehead

Ruddy duck

Hooded merganser

Red-breasted merganser
SCIENTIFIC NAME

Anser albifrons

Chen caerulescens

Dendrocygna bicolor

Anas platyrhynchos

Anas rubripes

Anas fulvigula

Anas strepera

Anas acuta

Anas crecca

Anas discors

Anas americana

Anas clypeata

Alx sponsa

Aythya americana

Aythya collaris

Aythya valisineria

Aythya affinis

Bucephala albeola

Oxyura jamaicensis

Lophodytes cucullatus

Mergus serrator

Source: Chamberlain, 1957 
Chamberlain, J.L.

1957 Ecological study of a Gulf Coast marsh, Rockefeller Refugè, Grand Chenier, Louisiana. Unpublished Ph.D. dissertation, University of Tennessee.

Conant, R.

1975 A field guide to the reptiles and amphibions of eastern and central North America. Houghton Mifflin Company, Boston.

Lowery, G.H., Jr.

1974 Mammals of Louisiana and its adjacent waters. Louisiana State University Press, Baton Rouge.

01sen, R.B.

1975 Bird usage of spoil banks in the intermediate marshes of southwestern Louisiana. Unpublished masters thesis, Louisiana State University.

Perry, W.G.

1976 Standing crops of fishes of an estuarine area in southwest Louisiana. Proceedings: 30th Annual Conference S.E. Association of Fish and Wildlife Agencies 71-81. 
Agencies Contacted During the Preparation of the Environmental Assessment

U. S. DEPARTMENT OF THE INTERIOR

HERITAGE, CONSERVATION AND RECREATION SERVICE

18 th and 5 th Street $C$

Washington, D. C. 20240

U. S. WATER RESOURCES COUNCIL

2120 L. Street, Suite 800

N Washington, D. C. 20037

U. S. DEPARTMENT OF THE INTERIOR

Geological Survey

Reston, Virginia 22092

U. S. DEPARTMENT OF HOUSING AND URBAN DEVELOPMENT

Plaza Tower, 1001 Howard Avenue

New Orleans, Louisiana 70113

ADVISORY COUNCIL ON HISTORIC PRESERVATION

1522 K Street, Suite 510

N W Washington 20055

U. S. DEPARTMENT OF THE INTERIOR

BUREAU OF RECLAMATION

Herrying Plaza Box $\$ 4377$

Amarillo, Texas 79101

U. S. DEPARTMENT OF COMERCE - NOAA

NATIONAL MARINE FISHERIES

Duval Building

9450 Gandy Boulevard

St. Petersburg, Florida 33702

*0. S. DEPARTMENT OF COMMERCE

MARITIME ADMINISTRATION

Central Region Office

Number 2 Canal Street

New Orleans, Loulsiana 70130

U. S. DEPARTMENT OF AGRICULTURE

SOIL CONSERVATION SERVICE

P. O. Box 1630

Alexandria, Louisiana 71301

*FEDERAL ENERGY REGULATORY COMMISSION

Fort Worth Regional office

819 Taylor Street, Room 9A05

Fort Worth, Texas 76102 
NUCLEAR REGULATORY COMMISSION

1717 H Street, N W

Washington, D. C. 20555

U. S. ENVIRONMENTAL PROTECTION AGENCY (EPA)

Region 6 - First International Building

1201 Elm Street

Dallas, Texas 75270

U. S. ARMY CORPS OF ENGINEERS

New Orleans District

P. 0. Box 60267

New Orleans, Louisiana 70160

*DEPARTMENT OF TRANSPORTATION

D. S. COAST GUARD - EIGTH DISTRICT

Hale Boggs Federal Building

500 Camp Street

New Orleans, Louisiana 70130

U. S. DEPARTMENT OF THE INTERIOR

GEOLOGICAL SURVEY

Water Resources Division

Federal Building

300 East 8th Street

Austin, Texas 78701

U. S. DEPARTMENT OF THE INTERIOR

NATIONAL PARKS SERVICE

Southeast Region Office

1895 Phoenix Boulevard

Atlanta, Georgia 30349

*U. S. DEPARTMENT OF THE INTERIOR FISB AND WILDLIFE SERVICE

P. O. Box 44753

USL, Lafayette, Louisiana 70504

U. S. DEPARTMENT OF THE INTERIOR BUREAU OF LAND MANAGEMENT 7981 Eastern Avenue Silver Spring, Maryland 20910

DEPARMENT OF WILDLIFE AND FISHERIES

Wildife and Fisheries Building

400 Royal Street

New Orleans, Louisiana 70130

STATE OF LOUISIANA STREAM CONIROL COMMISSION

P. 0. Drawer FC

University Station

Baton Rouge, Loulsiana, 70893 
*LOUISIANA AIR CONTROL COMMISSION

325 Loyola Avenue

P. 0. Box 60630

New Orleans, Louisiana 70160

STATE OF LOUISIANA DEPARTMENT OF CULTURE, RECREATION AND TOURISM OFFICE OF STATE PARKS

P. O. Box 44426

Baton Rouge, Louisiana 70804

*DEPARTMENT OF COMMERCE

LOUISIANA OFFICE OF COMMERCE AND INDUSTRY

P. 0. Box 44185

Baton Rouge, Louisiana 70804

DEPARTMENT OF HEALTH AND HUMAN RESOURCES

OFFICE OF HEALTH SERVICES AND ENVIRONMENTAL QUALTIY

P. 0. Box 60630

New Orleans, Louisiana 70160

DEPARTMENT OF NATURAL RESOURCES

LOUISIANA GEOLOGICAL SURVEY

P. 0. Box G

Baton Rouge, Louisiana 70893

LSU Geology Buflding

DEPARTMENT OF NATURAL RESOURCES

OFFICE OF MINERAL RESOURCES (State Mineral Board)

P. O. Box 2827

Baton Rouge, Louisiana 70821

Natural Resources Buflding

*DEPARTMENT OF NATURAL RESOURCES

OFFICE OF CONSERVATION - GEOLOGICAL OIL AND GAS DIVISION

P. 0. Box 44006 - Capitol Station

Baton Rouge, Louisiana 70804

*LOUISIANA DEPARTMENT OF TRANSPORTATION AND DEVELOPMENT OFFICE OF PUBLIC WORKS

P. 0. Box 44155

Capitol Station

Baton Rouge, Louisiana 70804

LOUISIANA DEPARTMENT OF TRANSPORTATION AND DEVELOPMENT OFFICE OF COASTAL ZONE MANAGEMENT

Hoover Building Annex

2156 Woodale Blvd

Baton Rouge, Louisiana 70804

LOUISIANA DEPARTIENT OF TRANSPORTATION AND DEVELOPMENT

OFFICE OF HIGHWAYS

P. O. Box 44245 - Capitol Station

Baton Rouge, Loulsiana 70804 


$$
\text { C-4 }
$$

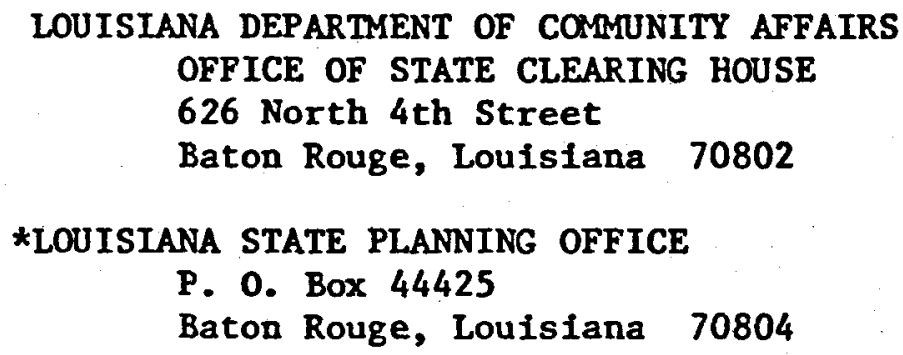

IMPERIAL CALCASIEU REGIONAL PLANNING AND DEVELOPMENT COMMISSION

*denotes agencies which responded to solicitation of comments 